Florida International University FIU Digital Commons

\title{
The Relationship of Instructor Technical Literacy to the Academic Performance of Students in Career Academies
}

Jorge Gomez

Florida International University, celestialproductions@gmail.com

DOI: $10.25148 /$ etd.FI13080910

Follow this and additional works at: https://digitalcommons.fiu.edu/etd

Part of the Bilingual, Multilingual, and Multicultural Education Commons, Curriculum and Instruction Commons, Curriculum and Social Inquiry Commons, Disability and Equity in Education Commons, Educational Assessment, Evaluation, and Research Commons, Educational Leadership Commons, Educational Methods Commons, Elementary and Middle and Secondary $\underline{\text { Education Administration Commons, Instructional Media Design Commons, International and }}$ Comparative Education Commons, Liberal Studies Commons, Other Education Commons, Other Teacher Education and Professional Development Commons, Secondary Education and Teaching Commons, Social and Philosophical Foundations of Education Commons, Special Education $\underline{\text { Administration Commons, Special Education and Teaching Commons, Urban Education }}$ $\underline{\text { Commons, and the Urban Studies and Planning Commons }}$

\section{Recommended Citation}

Gomez, Jorge, "The Relationship of Instructor Technical Literacy to the Academic Performance of Students in Career Academies" (2013). FIU Electronic Theses and Dissertations. 936.

https://digitalcommons.fiu.edu/etd/936 


\section{FLORIDA INTERNATIONAL UNIVERSITY}

Miami, Florida

THE RELATIONSHIP OF INSTRUCTOR TECHNICAL LITERACY TO THE ACADEMIC PERFORMANCE OF STUDENTS IN CAREER ACADEMIES

A dissertation submitted in partial fulfillment of the requirements for the degree of DOCTOR OF EDUCATION

in

ADULT EDUCATION

AND

HUMAN RESOURCE DEVELOPMENT

By

Jorge Gómez

2013 
To: Dean Delia C. Garcia

College of Education

This dissertation, written by Jorge Gómez, and entitled The Relationship of Instructor Technical Literacy to the Academic Performance of Students in Career Academies, having been approved in respect to style and intellectual content, is referred to you for judgment.

We have read this dissertation and recommend that it be approved.

$\begin{array}{r}\hline \text { Dawn E. Addy } \\ \hline \text { Erskine S. Dottin } \\ \hline \text { Tonette S. Rocco } \\ \hline \text { Thomas G. Reio, Jr., Major Professor }\end{array}$

Date of Defense: June 28, 2013

The dissertation of Jorge Gómez is approved.

\begin{tabular}{r} 
Dean Delia C. Garcia \\
College of Education \\
\hline Dean Lakshmi N. Reddi \\
University Graduate School
\end{tabular}

Florida International University, 2013 
(C) Copyright 2013 by Jorge Gómez

All rights reserved. 


\section{DEDICATION}

To my father Jorge A. Gómez, my intellectual mentor Dr. Rolando A. Amador, and Dr. Dominic A. Mohamed.

My father gave up everything, even his country so that his two sons could live in a land of freedom and opportunity. His hard work and outstanding example were the engines that drove the development of my character.

Rolando Amador was my intellectual father. I had never met a man who I admired as much. Even as his ideas and advice were relished by lawyers, judges, and intellectuals all over the world, he was a simple and approachable man. He was my teacher, my mentor, my lifelong friend, and the one person who early in my life recognized my potential. The spark he lit would last a lifetime.

Dominic Mohamed opened doors for many teachers in vocational education. His work remains a great legacy in South Florida and in many other areas. His pioneering spirit inspired me to join in an effort to refine the skills of teachers in Career Technical Education.

This accomplishment would not have been possible without their example, their dedication, and their belief in my potential. 


\section{ACKNOWLEDGMENTS}

Pursuing doctoral studies while working full time can be a challenging proposition. Add to that the inevitable obstacles and other circumstances that married life present, and you have a possible disheartening scenario. Writing a dissertation requires a singular focus from the student, and a considerable amount of time away from all other responsibilities.

It has been many years since the first meeting with my original dissertation professors, following the successful defense of my comprehensive exams. I distinctly remember Dr. Tonette Rocco asking me this question: when do you believe you will complete your dissertation? I said that I expected to finish long before the spring of 2009. My answer seemed very conservative at the time.

During the next five years, changes at the university would shift the composition of my dissertation committee due to the retirement or displacement of all but one of the members, Dr. Rocco. I am deeply grateful to her for having stuck with me all these years, always offering valuable advice and contributions. A special gratitude goes to Dr. Thomas G. Reio, Jr., who became my major professor and dissertation chair following the retirement of my original advisor and mentor, Dr. Dominic Mohamed. Beyond his incredible knowledge and expertise, Dr. Reio contributed a large dose of faith and confidence in my ability to jump over every obstacle and defend successfully. My deep appreciation goes to Dr. Dawn Addy and Dr. Erskine Dottin, who provided very valuable feedback and encouragement as part of my dissertation committee. I must also recognize 
Ms. Caprila Almeida and Ms. Katie Schmidbauer, members of the College of Education staff, who helped navigate the multiple procedures and deadlines. Many friends, relatives, and co-workers have been indirectly involved in helping me achieve this goal. They have patiently put up with me when I had no time for anything other than my studies. The faith of my church brothers and sisters has sustained me, even when they may not have understood why this pursuit was so important to me. They reminded me where my strength comes from and they prayed that I would successfully "move that mountain".

My greatest thanks are reserved for the one who deserves the honor and all the glory, my Heavenly Father. Since I was a child, I learned that He would never abandon me nor forsake me. May this accomplishment serve to expand my tent and serve your Kingdom here on Earth. 


\title{
ABSTRACT OF THE DISSERTATION \\ THE RELATIONSHIP OF INSTRUCTOR TECHNICAL LITERACY TO THE ACADEMIC PERFORMANCE OF STUDENTS IN CAREER ACADEMIES
}

\author{
by \\ Jorge Gómez \\ Florida International University, 2013 \\ Miami, Florida \\ Professor Thomas G. Reio, Jr., Major Professor
}

Career Academy instructors' technical literacy is vital to the academic success of their students. This nonexperimental ex post facto study examined the relationships between the level of technical literacy of instructors in career academies and student academic performance. It was also undertaken to explore the relationship between the pedagogical training of instructors and the academic performance of their students.

Out of a heterogeneous population of 564 teachers in six targeted schools, 136 teachers $(26.0 \%)$ responded to an online survey battery of four scales designed to determine teacher technical literacy, attitude toward technology, and their use of information and communications technology. Only 21 of the respondents in five of the schools had learning gains data for their students, therefore only these respondents participated in the final study. The survey was also designed to gather demographic and teaching experience data. Each demographic item had been linked by researchers to teachers' technology use in the classroom. Student achievement was measured by student learning 
gains as assessed by the reading section of the FCAT from the previous to the present school year.

Linear and hierarchical regressions were conducted to examine the research questions. To clarify the possibility of teacher gender and teacher race/ethnic group differences by research variable, a series of one-way ANOVAs were conducted. As revealed by the ANOVA results, there were not statistically significant group differences in any of the research variables by teacher gender or teacher race/ethnicity. Greater student learning gains were associated with greater teacher technical expertise integrating computers and technology into the classroom, even after controlling for teacher attitude towards computers. Neither teacher attitude toward technology integration nor years of experience in integrating computers into the curriculum significantly predicted student learning gains in the regression models.

Implications for HRD theory, research, and practice suggest that identifying teacher levels of technical literacy may help improve student academic performance by facilitating professional development strategies and new parameters for defining highly qualified instructors with $21^{\text {st }}$ century skills. District professional development programs can benefit by increasing their offerings to include more computer and information communication technology courses. Teacher preparation programs can benefit by including technical literacy as part of their curriculum. Finally, state certification requirements could be expanded to include formal surveys to assess teacher use of technology. 


\section{TABLE OF CONTENTS}

CHAPTER

PAGE

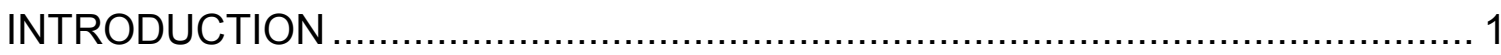

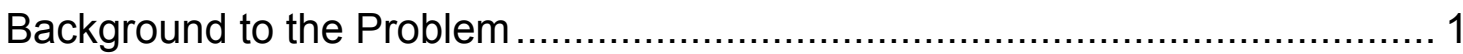

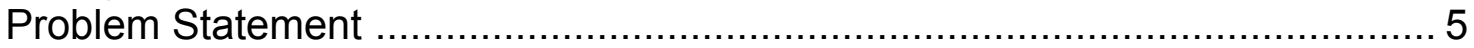

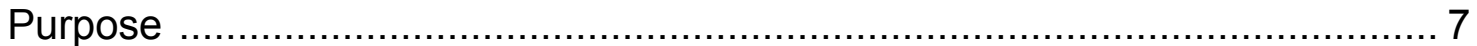

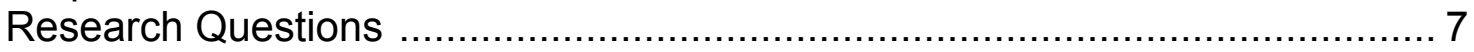

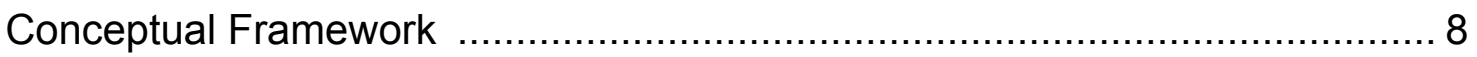

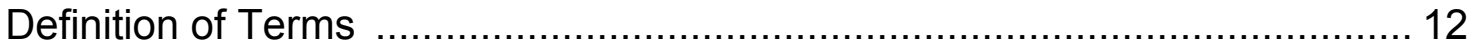

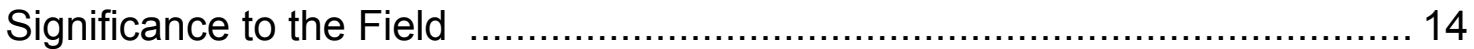

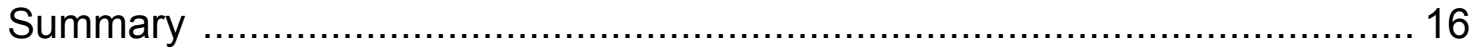

REVIEW OF THE LITERATURE …....................................................... 17

The Changing Global Workplace.......................................................... 17

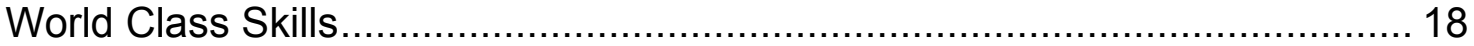

Integration of Computer Use in the Classroom .......................................... 19

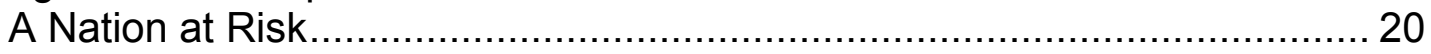

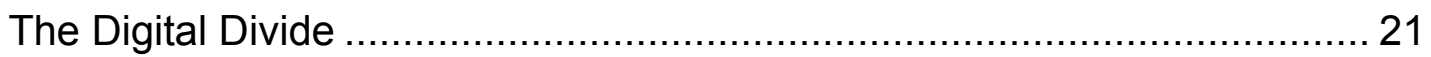

Influence of Teacher Technology Use on Instructional Practices ................ 22

Integration of Technology into the Curriculum ....................................... 24

Socioeconomic, Gender, and Cultural Influences in ICT .......................... 26

The Digital Divide and Students with Intellectual Disabilities...................... 26

A New Paradigm for Career and Technical Education ................................. 28

The Career Academy Model of School Reform ........................................... 29

Teacher Technical Literacy and Pedagogical Training ............................... 31

Information and Communication Technology Literacy ................................. 32

CTE Accountability Requirements ...................................................... 33

State Certification Requirements for CTE Teachers ……........................ 34

The Academy Teacher as Industry Role Model .......................................... 34

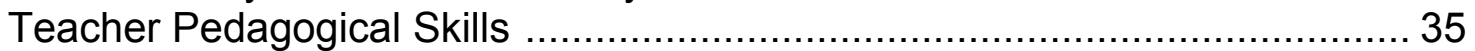

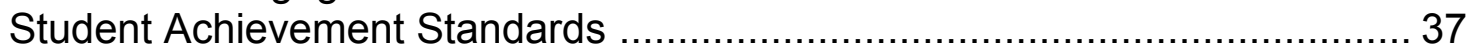

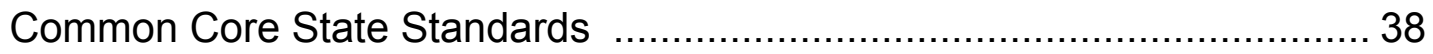

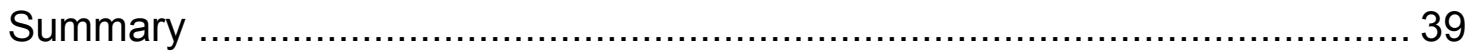

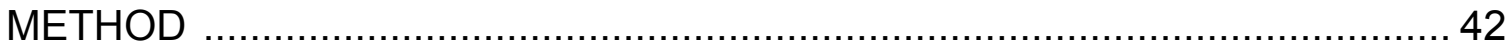

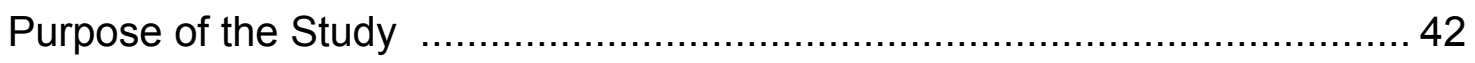

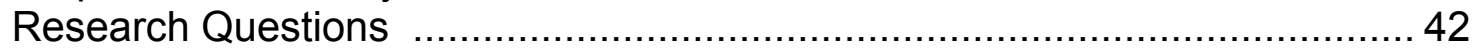

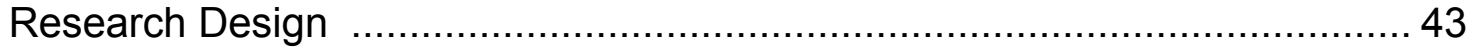

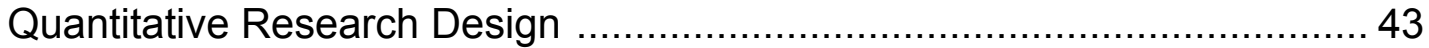

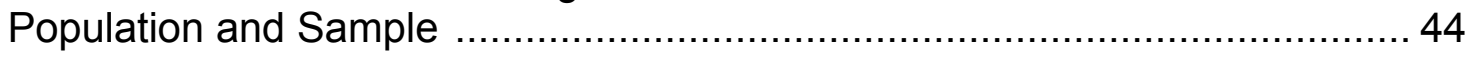

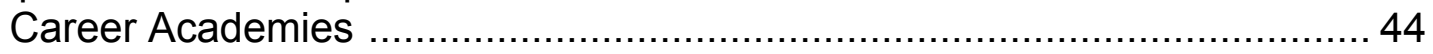

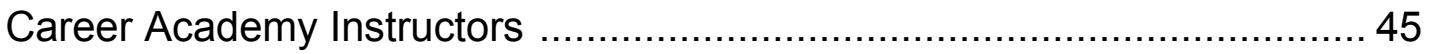

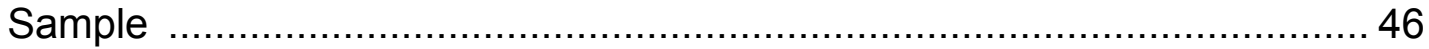

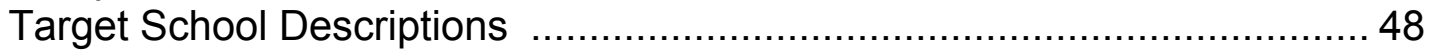




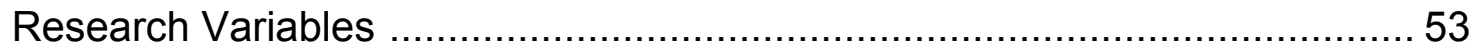

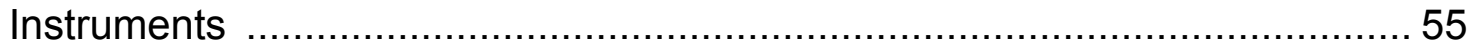

Teacher Technical Literacy and Attitudes Toward Computer Use ............. 55

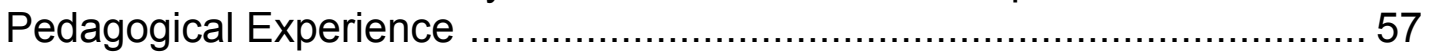

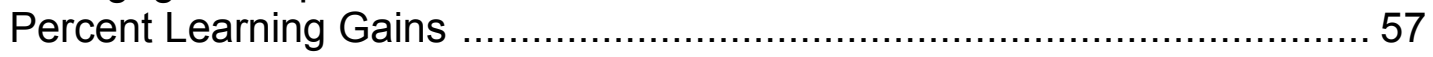

Computing Percent Learning Gains ……...................................... 58

FCAT Development and Validation ............................................... 58

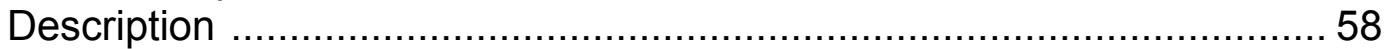

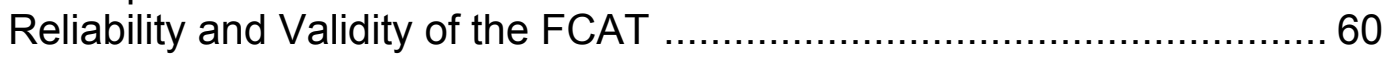

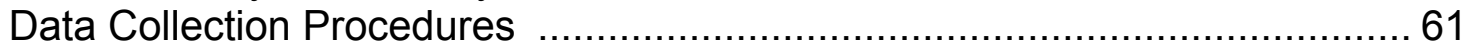

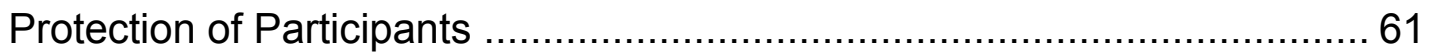

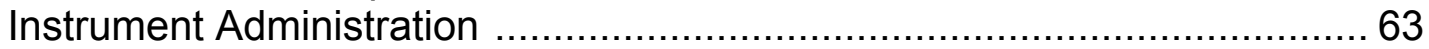

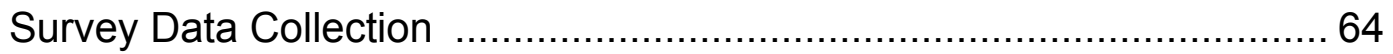

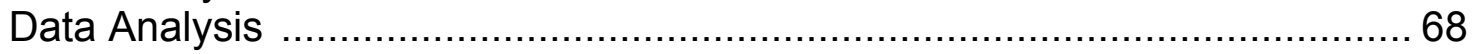

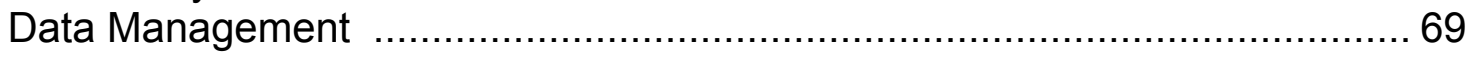

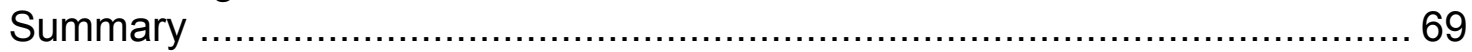

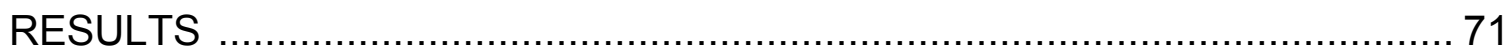

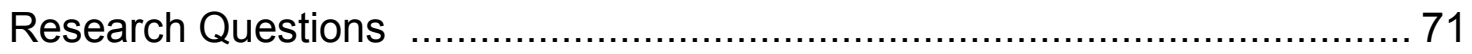

Demographic Characteristics of the Sample .......................................... 73

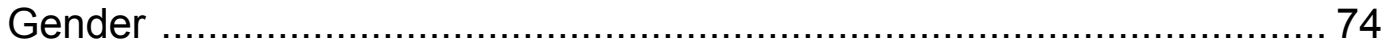

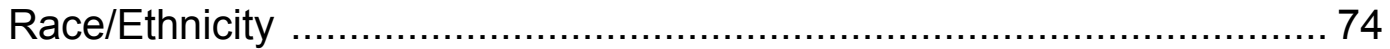

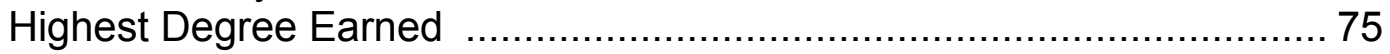

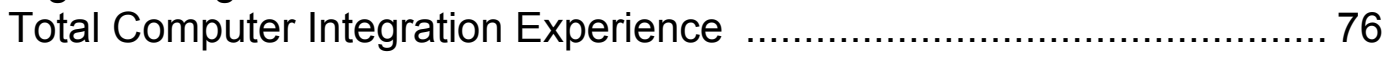

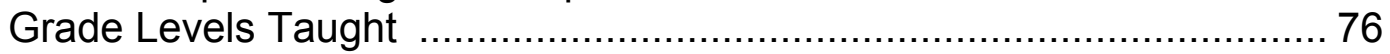

Subject/Vocational Areas Taught ................................................. 76

Years of Experience Integrating Computers into the Curriculum ............ 77

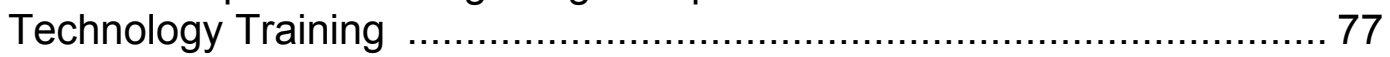

Average Number of Students in a Class ........................................... 77

Number of Computers Available for Student Use ............................... 77

Student Access to Computer Lab .................................................. 77

Cross Tabulations of Background Demographic Variables .................... 79

Testing the Research Hypotheses ........................................................ 81

Zero -Order Correlations Among Research Variables ............................ 81

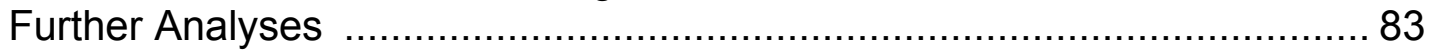

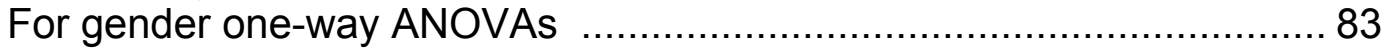

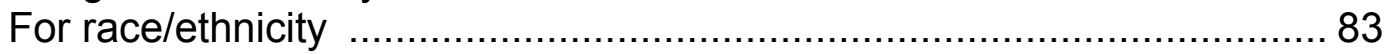

Testing Hypothesis 1: Linear Regression Analysis ................................ 85

Testing Hypothesis 2: Linear Regression Analysis ................................ 86

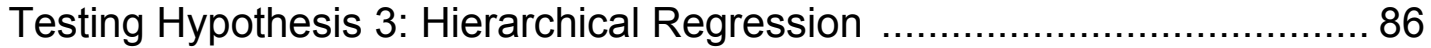

Testing Hypothesis 4: Hierarchical Regression ...................................... 87

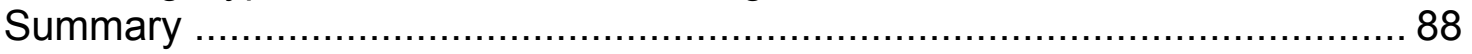

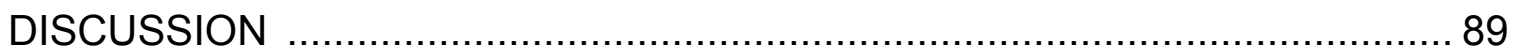

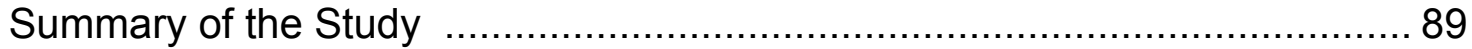

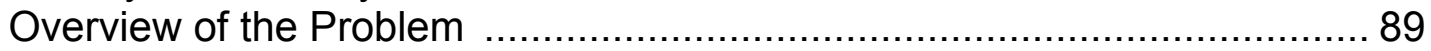




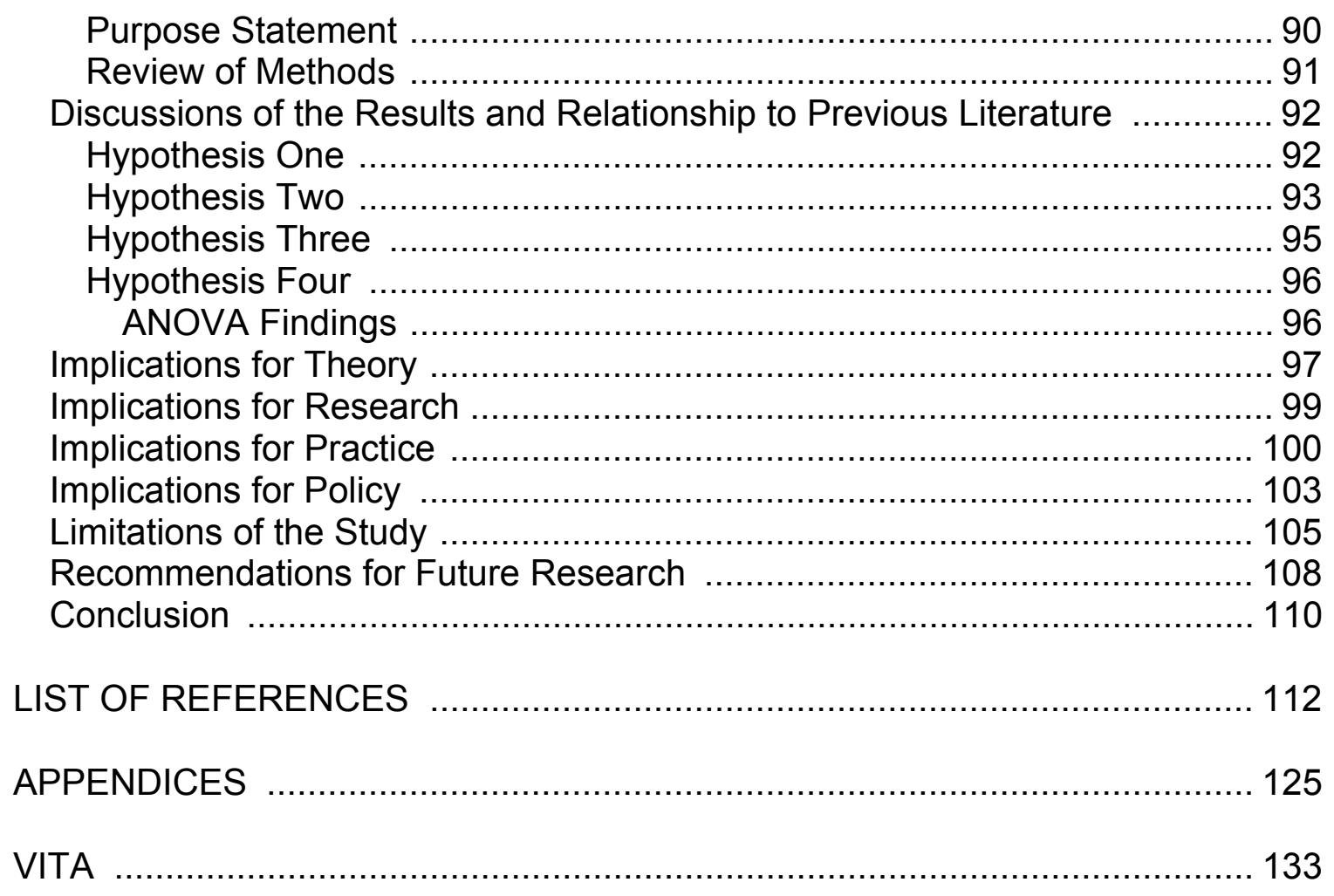




\section{LIST OF TABLES}

TABLE

PAGE

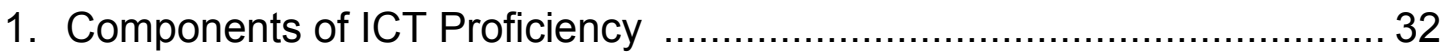

2. Gender and Racial/Ethnic Demographic Characteristics ...................... 47

3. Racial/Ethnic Composition of Career Academy Students by School ...... 53

4. Sample Items on Teacher's Attitudes …................................................. 57 Toward Computers Questionnaire

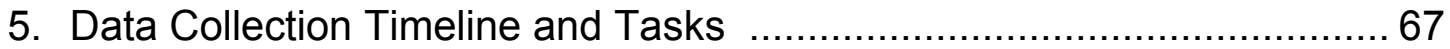

6. Frequencies and Percentages of Demographic ................................. 78 Characteristics of the Sample

7. Cross Tabulations of Demographic Variables ...................................... 79

8. Descriptive Statistics and Cronbach's Alpha ..................................... 80

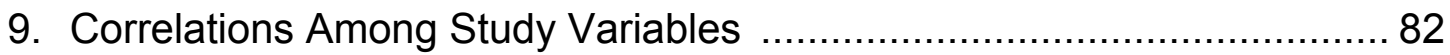

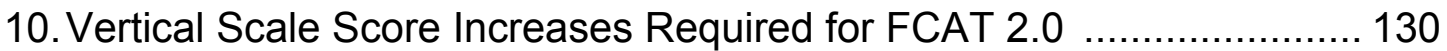
Reading Learning Gains 


\section{CHAPTER I \\ INTRODUCTION}

This correlation exploratory study examined the relationship between the level of technical literacy of instructors in career academies and the reading academic performance of students in technical and academic subjects. This chapter presents the background to the problem, problem statement, purpose of the study, and research questions that guided the study. The theoretical framework, definition of terms, significance to the field, and organization of the study are also presented.

\section{Background to the Problem}

Over the past three decades, advances in computer technology and the development of the World Wide Web have brought about a revolution in the way business is done. The vast interconnectivity provided by increased bandwidth over the Internet has facilitated the growth of a global network of companies vying for a share of the world's economic and human resources (Partnership for $21^{\text {st }}$ Century Skills, 2003). As a result, the global economic emphasis has shifted from the traditional local manufacturing of durable goods, to providing services and support for a burgeoning commerce of electronic hardware, computer software, multimedia file sharing, and information mining technology (U.S. Department of Commerce, 2002, 2004).

Today's economy is increasingly based on providing highly skilled services. The need to train workers in higher-order critical thinking skills and technological savoir-faire has become, arguably, a matter of national security in 
protecting the economy of any country competing in the global market (Friedman, 2007). Therefore, staying competitive requires maintaining technological advantage, both in connectivity and the training of workers (Benton Foundation, 2008). Multinational companies, no longer limited to their local workforce, search worldwide for the best-trained workers at the best value. Thus, the level of technical literacy of the workforce in the different areas or countries determines the trajectory of jobs and the extent of investment capital (National Governors Association, 2008). Technical literacy is the ability to read, write, interpret, analyze, and communicate in a career and technical field (Rhodes, 2003). The ability to use mathematics and science skills in problem solving tasks is also directly related to particular jobs or careers (Wonacott, 2001). As a result of this evolution of specialized skills in industry, technology has created a hierarchy of jobs dependent on the level of training of the individual. Jobs requiring lesser skills have been either automated or reduced to the level of semi-skilled labor, while the higher-paying jobs require more specialized skills and training.

Complex technology used in today's workplace has raised the technical skill standards for workers (Grubb \& Lazerson, 2005). As job qualifications change in industry, flexibility in transferring and updating skills to meet the new requirements, as well as developing new skills, is the best assurance for workers to remain competitive and retain their employment (Thijssen, Van de Heijden, \& Rocco, 2008). Career and technical education (CTE) has been a traditional means of training a capable, competitive workforce and for transitioning motivated secondary students from a general education to post-secondary 
training leading to an occupation or career in a chosen career path, such as automotive service technology, computer information, health technology, journalism, telecommunications, and the visual arts (Stone, 2002; Vocational Information Center, 2010). Higher technical skills standards at work require higher technical and academic standards in CTE programs to meet workforce training needs (Pucel, 1999; Daggett, 2004). This is especially true in developing nations that are still in the process of building the necessary information and communication infrastructure to meet business and industry's needs (U.S. Department of Labor [USDOL], 2001). The trend among adults seeking workrelated courses is to receive instruction from industry providers and professional associations closely related to the participants' employer, utilizing industryspecific technology and recent technological innovations (NCES, 2008). This entails for educational institutions considerable expenditure in curriculum, laboratory equipment and materials, and professional development for their instructors. Taking into account the high-stakes nature of being globally competitive, it is in the interest of industry partnerships to help relieve some of the investment. In 2005, approximately $88 \%$ of adult participants received some sort of financial support to participate in these courses from their employers (NCES, 2008, p. 209).

The number of secondary students participating in occupational studies remained stable from 1990 to 2005 . During the same period, the number of undergraduates seeking credit in the career fields increased by a half million students (NCES, 2008). This might indicate an important trend by high school 
graduates to target occupational post-secondary studies as a serious option to obtaining an academic college degree. Yet, many schools remain entrenched in a system originally designed to train students on a dual track: challenging academics for the college-bound elite, and less challenging academics for students in the vocational track (Dagget, 2004). Career Academies provide a vital bridge from the academics-based curriculum of traditional secondary programs and the real-world fundamentals of post-secondary Career and Technical Education programs. This divide is even more poignant between traditional liberal arts universities and career-oriented colleges. The labor market prospects for students in post-secondary education are also improved as they enter the technical fields with a more solid background and a clearer outlook of what awaits them (Hull, 2003).

Career academies are usually formed as small learning communities based on one particular career path in a technological field. Students in Grade 9 choose the career path they will follow, and they become part of a cohort that share the same curriculum, classroom and laboratory facilities, and teachers throughout their secondary education (Kemple, 2004). Career academies emerged in the last part of the twentieth century as a result of educational research supporting the integration of rigorous academic standards within a career and technical education framework as necessary to face the greater challenges of building a capable workforce for the $21^{\text {st }}$ century (Bottom \& Sharpe, 1996). Simultaneously, the concept of using small learning communities as a model of high school reform was gaining credence from the emerging research 
recognizing the value of increased student academic achievement in these smaller settings (Raywid, 1996).

\section{Problem Statement}

The increasing popularity of career academies as an effective model of secondary school reform has created a need for specialized instructors (Kemple 2004). The shortage of experienced CTE teachers has led to the practice of hiring traditionally trained teachers without industry experience in the technical fields or appropriate technical preparation in CTE (Office of Vocational and Adult Education [OVAE], 2000). Conversely, CTE teachers coming from industry with only alternative certification may lack training in high-order academics, pedagogy, curriculum development skills, and classroom management skills (Daggett, 2004). The issue at hand is that student academic and technical performance may be affected by their instructors' lack of technical and industry experience or pedagogical skills. The focus of this study is on the impact of technical knowledge on student learning, and albeit they may be equally important, industry skills and pedagogy form the subject for subsequent studies. Student academic performance is defined for the purpose of this study as the cognitive and meta-cognitive skills traditionally required in career and technical fields. The ability to use critical thinking, mathematics and science skills, technical language, and specialized skills in career-specific tasks is directly related to achieving success in industry (Rhodes, 2003; Secretary's Commission on Achieving Necessary Skills [SCANS], 1991; United States Department of Labor [USDOL], 2001; and Wonacott, 2001). Equally important are the social and 
self-management skills that are needed to survive in today's global workplace (Zins et al., 2004). Additionally, there are important skills necessary in almost every career field to communicate, access the resources needed, and conduct research through the use of technology and the Internet (International Information and Communication Technology Literacy Panel, 2004). According to the literature, equally important for instructors to be effective are the ability to manage the instructional setting, design curriculum and instruction, and use the best instructional practices (Daggett, 2004).

However, little information is available to link career academy instructor technical and pedagogical training to the academic performance of students. Existing research is mostly focused towards examining the effects of integrating CTE curriculum and instructional methods with traditional high-order academic skills otherwise reserved for the college-bound. The technical literacy of career academy instructors has been addressed in the literature as a professional development issue, but no direct association has been established to its possible relationship to the academic success of career academy students. Specific studies linking instructors' pedagogical skills to the academic success of students are also lacking. More research is needed to examine the possible relationship between career academy instructor technical literacy and pedagogical experience or training and the academic performance of career academy students. 


\section{Purpose}

The purpose of this exploratory correlational study was to examine the relationship between the level of technical literacy of instructors in career academies and the academic performance of students in academic and technical subjects. A subsidiary area studied was the relationship between the pedagogical training of instructors in career academies with alternative certification and the academic performance of students.

\section{Research Questions}

The main research questions were as follows:

1. What is the degree of relationship between the technical literacy of career academy instructors and the academic performance of career academy students?

2. What is the degree of relationship between the level of pedagogical experience of career academy instructors and the academic performance of career academy students?

3. After controlling for teacher attitudes toward technology integration, what is the degree of relationship between teacher technical literacy and student academic performance?

4. After controlling for teacher attitudes toward technology integration, what is the degree of relationship between teacher pedagogical experience and student academic performance?

Four null hypotheses were tested to examine these research questions: 
1. There is not a positive relationship between the technical literacy of career academy instructors and the academic performance of career academy students.

2. There is not a positive relationship between the level of pedagogical experience of career academy instructors and the academic performance of career academy students.

3. After controlling for teacher attitudes toward technology integration, there is not a positive relationship between teacher technical literacy and student academic performance.

4. After controlling for teacher attitudes toward technology integration, there is not a positive relationship between teacher pedagogical experience and student academic performance

\section{Conceptual Framework}

Responding to the need for skilled agricultural and manufacturing labor, the Smith-Hughes Act of 1917 placed an artificial chasm between academic and vocational programs by creating a funding structure for career technical programs separate from the traditional academic programs (Benson \& Hayward, 1993). The intent was to train individuals perceived as less capable of benefitting from a university education to supply the growing demand for workers in the trades. Some respected contemporary educators instead supported the concept of integrating vocational and academic instruction as an alternative to the segregation of college bound students from students in vocational programs (e.g., Dewey, 1916). In their view, the use of occupations as the center of a 
meaningful education must include the development of artistic and scientific abilities and challenging intellectual and moral growth:

Education through occupations consequently combines within itself more of the factors conducive to learning than any other method. It calls instincts and habits into play, it is a foe to passive receptivity. It has an end in view, results are to be accomplished. Hence it appeals to thought, it demands that an idea of an end be steadily maintained, so that activity cannot be either routine or capricious. (Dewey, 1916, p. 361)

Dewey (1916) believed a democratic society would not be possible without high quality, contextually rich academic and vocational education. Learning with a purpose transforms concrete actions into meaningful experiences (Dewey, 1938).

Likewise, more recently Vygotsky believed that purposeful learning in a meaningful contextual setting expanded the possibilities of development in a culturally positive direction within the learner's zone of proximal development (Vygotsky, 1978). The difference between a child's independent developmental level and the child's ability to solve problems under adult or peer guidance is referred to as the zone of proximal development, and is the cornerstone of a vital modern concept regarding human learning. Cognitive structures develop in a meaningful context, with language and social interactions serving to help the learner construct new meaning, using previously learned concepts (Vygotsky, 1930). Cognitive structures are patterns of physical or mental action that develop as an individual interacts with the real world. They take the shape of language and cultural intellectual expressions that we communicate to others (Vygotsky, 1930). The value of social interaction in child development is related to the child's ability to imitate others and function at a higher level than their own independent 
functioning level, "human learning presupposes a specific social nature and a process by which children grow into the intellectual life of those around them" (Vygotsky, 1978, p. 88).

An important link to career academies exists in Vygotsky's assumption that a child's identity develops in a sociocultural context (Werstch, 1985). The traditional learning methods of formal apprenticeships from which CTE evolved required that an apprentice become a part of the master's guild (Epstein, 1998). This allowed the child to be involved not only in learning the master's trade, but also to participate in his social environment, which included relations with other members of the trade. Rules and modalities of the guild were part of daily practice and would become as second nature to the apprentice. After seven years, the apprentice became a journeyman, and eventually a master within the guild. Today's career academies are similar to these guilds in that the child chooses one of 16 clusters to follow in his/her studies and joins a cohort, which may last through their entire secondary career (Kemple, 2004). Beyond the core academic and career-related courses, members of the cohort share all laboratory and social activities related to their cluster. They also share the same teachers and advisors for the duration of their secondary experience. Industry technical advisory committees function as a link to the trade and provide teachers an opportunity to relate to the latest industry standards, and on-the-job training and apprenticeship opportunities for students. Socialization provides a great opportunity for informal learning in an environment that in most cases mimics the actual industry workplace (Hull, 2003). 
A sociocultural approach to learning provides a new lens through which to regard contextual learning in the zone of proximal development. Education becomes a collaborative social enterprise in which the students' prior knowledge and experience contribute to the design and development of their learning (Bonk \& Kim, 1998). Patterns of activity occur in a social context, and are internalized by the learner, in time becoming second nature to the student. Scaffolding techniques used in cognitive apprenticeships allow students to experience success at replicating social activities while at the same time providing needed support and instruction until the activity is mastered. Intersubjectivity, or the way groups of people share feelings about the world around them helps establish a common focus and foster mutual respect among student/teacher team members (Bonk \& Kim, 1998). In the career academy context, the instructor or academy leader becomes the center of social interaction, much like the Master in a formal apprenticeship. It is of great importance for instructors to model proficiency in utilizing industry's latest and most effective best practices, including technical and information communication technology (ICT) literacy. Technical information is language, mathematical, and scientific information that is directly related to the core career path or theme. ICT is related to the use of computers and web-based tools necessary for survival in any technical career. Technical skills and technical literacy in the context of this study refer more generally to the ability to manipulate ICT tools and language, and not so much to skills specifically related to the career technical field at the core of the academy. 
The increased use of new learning forums, including formal or informal synchronous and asynchronous meetings carried out using the World Wide Web, telephone and video teleconferencing and even instant messaging using mobile technology are changing the traditional concept of classroom instruction (Bonk \& Kim, 1998). The new face of education is more like a diverse collage of global proportion, as the sociocultural context of learning adopts values that closely reflect the practices and traditions of the modern workplace (Zins et al., 2004).

\section{Definition of Terms}

Academic performance. Cognitive and meta-cognitive skills traditionally required in industry, including the ability to use mathematics and science skills, technical language, and specialized skills in career-specific tasks directly related to achieving success in a particular career path or trade (Rhodes, 2003;

Wonacott, 2001, USDOL, 2001). This includes the social and self-management skills needed to survive in today's global workplace (Zins et al., 2004).

Advisory committees. School-based groups composed of volunteer members of industry in the community. They provide advice on curriculum development, job relevant skills and serve as resources for internships, apprenticeships, and job opportunities for students (Dagget, 2004).

Bandwidth. The difference between the limiting frequencies within which performance of a device, in respect to some characteristic, falls within specified limits (American National Standards Institute [ANSI], 2001).

Broadband. A descriptive term for evolving digital technologies that provide consumers a signal-switched facility offering integrated access to voice, 
high speed data service, video-on-demand services, and interactive delivery of services (ANSI, 2001).

Career academies. Small learning communities centered on specific career clusters or trades. Instructors and students combine high academic standards and technical skills within a meaningful vocational context (Kemple, 2004).

Connectivity. The ability to connect to the World Wide Web and other computer-based networks, such as limited access networks (LANs), to access information, perform training and work-related tasks, and communicate and interact with other users (WOS, 2006).

Information and communication technology (ICT) literacy. The ability to communicate, locate information, and conduct research through the use of technology and the Internet. "ICT literacy is using digital technology, communications tools, and/or networks to access, manage, integrate, evaluate, and create information in order to function in a knowledge society." (International Information and Communication Technology Literacy Panel, 2004, p.10).

Integration of vocational and academic curricula. Programs combining challenging, high-level mathematics, science, and language arts, with technical studies in a career-centered context (Bottom \& Sharpe, 1996).

Intersubjectivity. The way a group of people feel about their social setting, including shared values, goals, language, customs, and meaning (Bonk \& Kim, 1998). 
Numeracy. Mathematics skills related to solving real-world problems (Rhodes, 2003).

Pedagogical Technology. Model and facilitate effective use of current and emerging digital tools to locate, analyze, evaluate, and use information resources to support research and learning (International Society for Technology in Education, 2008).

Technical literacy. The ability to read, write, interpret, analyze, and communicate in a specific field; it also involves the ability to use mathematics and science skills in problem solving and performing tasks related to the job or career (Wonacott, 2001; Rhodes, 2003).

Zone of proximal development. "The distance between the actual development level as determined by independent problem solving and the level of potential development as determined through problem solving under adult guidance or in collaboration with more capable peers" (Vygotsky, 1978, p.86)

\section{Significance to the Field}

Career academies focus on specific career clusters using technical and professional skills as a platform for instruction (Grubb, 1997). Learning abstract academic concepts through solving problems in an environment full of real world contextual meaning is perhaps more effective for most students than traditional academic models (Bottom \& Sharpe, 1996; Dagget, 2004; Dewey, 1916; Pucel, 1999). The wider appeal to students and meaningful integration of high-level academic and technical skills in a career context contribute to make career 
academies a popular and effective model of secondary instruction (Kemple, 2004).

At the core of career academies are the instructors and leaders of career and technical education (CTE). They function as facilitators and links to industryrelevant curriculum and future job connections (Kemple, 2004). Their ability to communicate with industry experts and leaders, and share updated information with their students are of vital importance. Equally important is their ability to transfer knowledge to students in an effective manner. Instructors for career academies need both pedagogical and industry-specific technical literacy skills to fulfill their roles (Dagget, 2004).

The results of this study may inform Vygotsky's theory of contextual learning by examining the possible relationship of competent adults' influence on the apprentice learner (Vygotsky, 1978). They may also add to the empirical research in career and technical education by exploring the possible dynamic relationships that exist in the career academy classroom or laboratory and how they affect student academic performance. Finally, they may help shape present policy and practice by stressing the importance of using instructors with competent skills (Daggett, 2004), and updating the skills of instructors already in the classroom. Pre-service teacher training programs, human resource (HR) and professional development practitioners, and secondary school administrators may find this research useful in identifying best classroom/laboratory practices and career academy instructors who require specific professional development in technical literacy and/or pedagogical and classroom management skills. 


\section{Summary}

Competition in a global economy for high skills, high-wage jobs has changed the parameters for training a workforce in the twenty-first century. Today's workplace requires students to learn high order critical thinking, math, science, and communication skills (USDOE, 2006). The increased use of career academy programs as a platform from which to launch secondary career-focused integrated academic programs creates a high demand for career academy instructors with world-class academic training, as well as industry-specific technical literacy skills. Classroom and laboratory management and pedagogical skills are also vital for teachers to be effective in training the workforce.

Chapter 1 discussed the background of the problem and the purpose of the study, the study's rationale and presented the primary research questions, the theoretical framework of the study, and definitions of key terms. Significance of the research to the field of AE/HRD was also discussed. Chapter 2 comprises the review of the literature. Chapter 3 explains the research design. Chapter 4 discusses the findings for each of the areas investigated; the discussion includes the data description and data analysis for each question. Chapter 5 contains conclusions and recommendations for $\mathrm{AE} / \mathrm{HRD}$ and further research based on the findings. 


\section{CHAPTER TWO}

\section{REVIEW OF THE LITERATURE}

This chapter begins with an overview of advances in computer technology and the development of the World Wide Web in the last thirty years, and how those advances have influenced the way business is done. A brief history follows about the efforts made by the United States Congress to align the goals of education with the need to train a capable workforce with the advancing technologies to compete in a global economy. Discussion follows on the results of empirical studies conducted at the behest of Congress which exposed a gap in the technical skills of teachers that might have an effect on student performance. The possible gaps in pedagogical skills of teachers with alternative certification are also discussed. The role of career technical education in developing a competent workforce is discussed, along with an abbreviated synopsis of how the career academy model of school reform developed as a response to the need for training a capable workforce, and the teacher's role as facilitator and role model in career academies. Finally, some implications are discussed as to how gaps in teacher technological and pedagogical skills might affect career academy student performance as reflected in the instructors' ability to model updated industry standards.

\section{The Changing Global Workplace}

Advances in computer technology and interconnectivity over the past thirty years have brought about a profound change in the way the modern workplace functions in the global economy to compete for a share of the world's 
economic and human resources (Daggett \& Pedinotti, 2005). Technology use has arguably made many repetitive tasks much easier, accurate, and less demanding of specialized training. Cash registers in fast food restaurants are a good example: no longer must the cashier press numbers to enter the amount; they simply press the icon representing the product, and the correct amount is displayed. Conversely, some technology requires highly specialized training and higher-order thinking for the operator to function effectively. This dichotomy creates a class divide between the highly skilled, higher wage workers, and the unskilled operator whose job pays much less and can even be completely automated and eliminated.

The demand for higher workplace skills is setting the pace at which education must evolve to successfully prepare students to have a competitive edge in society. Not only are workplace skills becoming more complex, but complex communication and technical survival skills, as well as an increasing abundance of daily personal choices for individuals to make, require that citizens become sophisticated in the use of high-order thinking and gain technological proficiency to take and maintain control of their own lives (Partnership for $21^{\text {st }}$ Century Skills, 2003).

\section{World-Class Skills}

Competing in a global economy requires skills that match or surpass those of our competitors. The development of effective mass production and scientific business management techniques, paired with an abundance of raw materials to support industrial manufacturing placed the United States far ahead of its closest 
foreign competitors during the 150 years following the Industrial Revolution, well into the second half of the twentieth century (Baumol, Nelson, \& Wolff, 1994). Aided by the existence of higher wages and a large affluent national market, America's mass production technological leadership was unsurpassed (Nelson \& Wright, 1994). The complex nature of the industries and the resources needed to sustain them made it difficult for other nations to replicate the success of U.S. manufacturers without making considerable investments in equipment, infrastructure, and technical education (Nelson \& Wright, 1994). These same factors set the path for the Japanese and some European countries to achieve a convergence of computer and robotics technology capable of displacing the U.S. from its leadership role at the end of the $20^{\text {th }}$ century and into the $21^{\text {st }}$ century.

\section{Integration of Computer Technology Use in the Classroom}

Excitement over integration of technology into the classroom paralleled the meteoric rise of microcomputer development in the 1980s. Industry was making great strides incorporating the new technologies into their work plan, so it was important for education to follow suit and train the new waves of workers in using the tools available. In October of 1980, the United States Congressional House Committee on Education and Labor Subcommittee on Special Education commissioned a study by the Office of Technology Assessment to find out how information technology could be used for education and training (OTA, 1982). The study used existing archival data and surveys, as well as extensive case studies designed to explore different areas where educational technology could benefit stakeholders. Some of the findings reflect the complexity of the problems 
and obstacles facing integration of technology: the lack of adequate educational software and curriculum materials and expert programmers to produce them; skepticism surrounding the use of new teaching methods that had yet to be proven effective. The cost of providing hardware and software to schools that are already financially pressed for funds; inequities of access to the new technologies; and a lack of trained teachers to implement the new technologies also stood out as major obstacles. Two areas of special concern were the dearth of available technology for special needs students and the social and economic disparity affecting certain populations. Important trends were also recognized for the future, including the increasing availability of affordable hardware and software, and the significance of the ability to remotely train the workforce in the workplace, and even at home in the case of some special needs students (OTA, 1982).

\section{A Nation at Risk}

The publication in 1983 of $A$ Nation at Risk: The Imperative for Educational Reform: A Report to the Nation and the Secretary of Education, United States Department of Education by the National Commission on Excellence in Education documented the steep decline in the educational performance of students in the United States, "Our once unchallenged preeminence in commerce, industry, science, and technological innovation is being overtaken by competitors throughout the world" (U.S. National Commission on Excellence in Education, 1983, p. 9). Concerns over training a competent workforce led Congress to maintain a watchful eye on technology integration and 
to support further empirical studies on implementation across the nation's schools.

\section{The Digital Divide}

Significant progress was made in the last quarter of the $20^{\text {th }}$ century in the deployment of educational computer hardware and software. The percentage of schools having one or more computers available for instruction increased from $18 \%$ in 1981 to $95 \%$ in 1987 (OTA, 1988). However, a great disparity remained among schools and classrooms, with some schools having full computer labs, while others had few or no computers in the classroom. Additionally, computer use was described as limited to teaching about computer technology, rather than integrated into the curriculum (1988). This trend continued into the mid-nineties, with little or no significant progress made in integration of technology use into the curriculum. Becker (1998) reported an actual decline of student use of computers between 1989 and 1992 for anything other than word processing skills not necessarily related to the curriculum. Despite the fact that technology was becoming more abundant, limited investment in teacher training and support in using technology remained an issue (Becker, 1998). The descriptive statistical data for this report was obtained from Becker's own contractual study conducted for the Office of Technology Assessment (Becker, 1994). One caveat that needs consideration in reviewing the empirical data is the different definitions used by the researchers in what constituted teacher technology use, which may have caused the collection of data to be skewed (Bebell, Russell, and O'Dwyer, 2004). 


\section{Influence of Teacher Technology Use on Instructional Practices}

Policy makers in education may have expected that adding hardware and software to their classrooms would promote a new era in instructional practices for the $21^{\text {st }}$ Century. This was certainly the case in the workplace, where technology and connectivity became the game changer in global competitiveness (Daggett \& Pedinotti, 2005; Friedman, 2007). Would spending considerable amounts on the new technologies also promote revolutionary change in the instructional practices of teachers leading to student academic gains? Several studies explored this possibility, and some of the results may have proved disappointing.

In a qualitative study of two high schools located in California's Silicon Valley, Cuban, Kirkpatrick, and Peck (2001) examined teacher and student use of technology in the curriculum and how it influenced instructional practices. Their study was conducted in the 1998-1999 school year at two suburban California high schools, one with 1900 students and over 80 teachers, and the other with 1300 students and over 60 teachers. Subjects consisted of teachers enthusiastic and supportive of technology use, in an area considered to be America's heart for computer and technology companies. Student access to computers was slightly above average, as compared to nationwide estimates. Internet access was considerably higher than the national average. In many cases, teachers and students also had access to computers and the Internet at home, exceeding average classroom use. The study took place over 7 months, and consisted of teacher and student surveys, interviews, shadowing (observation), and archival 
record reviews of grants proposals seeking technology funding, newspaper articles about the schools, reform proposals, and evaluation data. Results of this study reinforced the view of the available literature reporting little evidence of student centered instruction using the technology. A continuation of teacher centered activities was observed, including lectures, review of class work/homework, working on assignments, and occasional use of low-tech hardware (Cuban, Kirkpatrick, and Peck 2001).

Becker and Ravitz (1999) explored the degree to which teacher use of technology influences constructivist teaching practices, and how teachers might recognize their use of technology as being important to their instructional style. The sample used in Becker and Ravitz's study consisted of 441 teachers in 151 elementary and secondary teachers in the U.S. participating in the National School Network (NSN), a project established by the National Science Foundation to bring together groups working on school reform through the use of technology (Becker \& Ravitz, 1999). Because of the focus and scope of the NSN project, the researchers expected a leaning towards constructivist pedagogy on the part of the participants.

Constructivist instructional methods add meaning and relevance to learning through the use of: a) student-centered instruction; b) collaborative group projects centered on contextual themes; c) focus on complex ideas such as collaborative projects using the Internet across the world, rather than rote memorization of terms and facts; d) self-reflection of students' learning; and e) Intersubjectivity of learning, where students and instructors learn together. 
Integration of technology in the curriculum may make these possible by creating a flexible student-centered interactive platform for instruction based on projects, as opposed to a traditional teacher-centered approach based on lectures and whole group instruction. Constructivist methodology emphasizes the use of technology for production of student projects and collaborative/interactive research, rather than simply as word processing and Internet search tools (Means \& Olson, 1995).

\section{Integration of Technology into the Curriculum}

One area of concern in the integration of technology in the classroom was teacher readiness to implement the plan. An empirical study by Bebell, Russell, and O'Dwyer used multiple measures on two levels to determine teacher and student use of technology (2004). At the teacher level, the outcome measures were: 1) teacher-use of technology for delivering instruction; 2) teacher-directed student use of technology during class time; 3) teacher-directed student use of technology to create products; 4) teacher-use of technology for class preparation;

and 5) teacher-use of email for professional purposes. At the organizational level, the outcome measures were: 1) restrictive policies; 2) funding for technology; 3 ) leaders' discussion of technology; 4) evaluations considering technology; 5) principal's technology-related discretion 6) technology-related professional development; 7) extent of focus on technology integration in professional development; and 8) school mean socioeconomic status (2004, p. 380). A hierarchical linear regression was used to analyze the data. The findings suggest that characteristics outside of the classroom may influence teacher use of 
technology. The study also suggested that previous research may have been influenced by various existing definitions of what constitutes teacher technology use. Part of the cause for this may be the rapid pace at which educational technology has evolved (Bebell, Russell, and O'Dwyer, 2004).

Integration of technology into the curriculum remained the single most difficult challenge for even the most technologically able teachers to overcome. Bauer and Kenton (2005) conducted a mixed methods study of 30 teachers previously identified through purposeful sampling as being highly proficient in computer technology use. The researchers used three sources of data collection: a pre-observation survey-questionnaire, a $30-45$ minute classroom observation, and an informal interview conducted soon after the classroom observation. Themes and categories were created using a constant-comparative method of data analysis. Statistical Package for the Social Sciences (SPSS) was used to analyze and organize the quantitative data collected (Bauer \& Kenton, 2005).

The study identified the following obstacles to full integration of computer technology into the curriculum, as opposed to mere computer use in the classroom: 1) difficulties with equipment, such as a lack of enough computers, inadequate or outdated hardware and software, and inability to run programs; 2) time-related constraints, such as not enough computer time per student, incompatible scheduling, and insufficient time allotted for training students in using technology; 3) varying levels of student expertise in the use of computers; 4) insufficient teacher training and professional development in the use of technology programs; 5) conflicting scheduling of computer lab time; 6) lack of 
compatibility and availability of reasonably priced hardware and software; 7) insufficient Internet access and inadequate bandwidth to allow all students simultaneous access. Results of this study underlined the increasing importance that computer technology can have as a curriculum and instructional tool. The study suggested that teachers need to be trained in the use of these tools, and administrators need to support the effort by providing the hardware, software, and connectivity to make integration possible (Bauer \& Kenton, 2005).

\section{Socioeconomic, Gender, and Cultural Influences in ICT}

The impact that Information and Communication Technology can have on leveling the inequalities existing between dominant society and the less fortunate social groups has long been recognized (Garcia \& Villanueva, 2001). The digital divide, as these technology inequalities are often described consists in low level of access to information and communication technology by various groups, characterized by poverty, inadequate infrastructure, illiteracy in traditional and computer communication, race, gender, and social status (ITU, 2005).

Dissemination of the technologies has been spotty at best in many developing countries (McNamara, 2003). The automation made possible by technology has

eliminated mid-level skills jobs, creating opposing classes of skilled and unskilled jobs with distinct economical and class advantages reserved for only the workers with the highest set of technological skills.

\section{The Digital Divide and Students with Intellectual Disabilities}

Paradoxically, access to educational technology has been limited for Students with Intellectual Disabilities (SID), a group that could greatly benefit 
from the use of technology. One of the most commonly identified barriers to computer and Internet use for SID students is the use of a keyboard and mouse as the input device for accessing the technology. Most software programs require basic typing or handwriting abilities that many of these students do not possess. High level reading abilities are also required to navigate and understand the programs, even without the need for keyboard input (Wehmeyer et al., 2004). Some adaptive programs use word recognition software that is beyond the speech articulation clarity of many SID students. Technical language associated with the use of technology offers the greatest hurdle for students with limited cognitive abilities.

Many of the largest publishers of educational curriculum materials have recognized the need to adapt their print materials for electronic consumption. This benefits students with specific print related disabilities, such as the visually impaired and the dyslexic, as well as students with intellectual disabilities and low levels of reading abilities (Jackson, 2004).

Several organizations also provide effective technology based solutions to help students with disabilities. Many of these resources are available at no cost to education providers. They include the National Center for Accessible Media, sponsored by the Corporation for Public Broadcasting, where eBooks can be downloaded; Alex, a collection of public access documents created by Erick Lease Morgan which is a catalog of public domain literature from American and English literature; and Bookshare, an online library published by Beneficent Technologies, Inc., where students with disabilities can browse an accessible 
book library (Jackson, 2004). There are many more. The plethora of online sources available underscores the need for teachers to be knowledgeable of the resources and to have the ability to locate and navigate around them, so they can teach their students how to use them.

\section{A New Paradigm for Career and Technical Education}

The transition from a manufacturing to a knowledge-based economy had profound consequences for the training of the workforce. Maintaining competitiveness in today's global economy meant keeping up with the complex nature of the new workplace: "The Knowledge Revolution (or the Information Society, or the Communications Revolution, or the High-Tech Revolution) has changed the nature of work, shifting away from occupations rooted in industrial production to occupations associated with knowledge and information" (Grubb \& Lazerson, 2005, p.1). Career and technical education's traditional role preparing students for the world of work also evolved. The need for higher order thinking, communication, mathematics and specialized technological and information technology skills requires schooling beyond the high school level. The level of technical literacy of the workforce and the ability to use critical thinking and mathematics and science skills in problem-solving tasks determines how effective workers will be in maintaining the jobs that might otherwise be outsourced to other countries (National Governors Association, 2008). Graduates entering the workforce find themselves competing not only with local contenders for the jobs, but with a wide range of highly capable individuals across the planet (U.S. Department of Commerce, 2002, 2004). The ease with which knowledge- 
based work can be outsourced has made our planet "flat", as Friedman (2007) famously dubbed our new global workplace, with an abundance of engineers, medical technologists, and accountants being produced by India and China in state-sponsored programs. Renewing intellectual resources to fit evolving workplace technology is essential to remain relevant in the world market. Defining and updating evolving skills is the best strategy for workers to remain competitive and retain employment (Thijssen, Van de Heijden, \& Rocco, 2008).

\section{The Career Academy Model of School Reform}

Following decades of vocational programs designed as an alternative for students not considering college careers, educational research in the later part of the $20^{\text {th }}$ century revealed what John Dewey believed all along: a rigorous program of studies, using a career path as a theme, would be more beneficial for all types of students, including the college-bound, giving essence and meaning to an otherwise vacuous education (Dewey, 1916). Simultaneously, students would have the added benefit of getting an early start towards training for a career of their choice (Bottoms \& Sharpe, 1996). Research also reveals that a smaller school setting helps students learn better by increasing the participation and commitment of both students and faculty members, and by providing a more personalized schooling experience (Raywid, 1996).

Established nearly forty years ago, career academies are small learning communities, usually within the framework of a larger school, and comprised of 150 to 300 students working as a cohort structured around a career path or theme throughout their high school career. Students may choose from a possible 
16 career clusters (not all clusters are offered at every school); they share the same career theme, and the same career technical and academic instructors and counselors, with community partners from industry providing valuable guidance and support to make the academies relevant to the real world (Kemple \& ScottClayton, 2004). Laboratories and classrooms may be set up to represent the actual workplace environment, and the social milieu should reflect that of a real world professional ambience. Academic and technical instruction is infused with the rigor that is equal to college preparatory courses, and extra help is available to ensure every student's success. The ability to use critical thinking, mathematics and science skills, technical language, and specialized skills in career-specific tasks is directly related to achieving success in industry (Rhodes, 2003; [SCANS], 1991; USDOL, 2001; Wonacott, 2001).

Research has shown that contextual teaching is most effective to facilitate learning, using five teaching strategies: a) relating to the subject matter, learning in a familiar context; b) experiencing, using project-based learning; c) applying what is learned to the specific context; d) cooperating by sharing and communicating with instructors and more capable peers; and e) transferring skills, using the knowledge gained to apply to new problems and situations within the same context (Hull, 2003).

Career technical instructors provide the expertise and practical experience to train students in the latest industry standards, while academic instructors relate their subject matter to specific skills required by the career theme. Common curriculum planning helps integrate career/technical and academic 
subjects using the career theme as the core of instruction. Rigorous expectations and additional help ensure that every student is able to achieve high academic standards regardless of their postsecondary or career plans (Bottoms \& Sharpe, 1996; Daggett, 2004). An important finding concerning career academies is the positive effect that they have on young graduates' prospects for finding a job or additional training within a career or technical field (Hull, 2003; Kemple \& ScottClayton, 2004). Students are exposed to on-the-job training opportunities, and extensive networking through business and community partners associated with the academies. Given the state of affairs in today's globally competitive economy, this can become a considerable contribution towards graduates' employment, and it gives students an early taste of real world employment, and today's workplace culture.

\section{Teacher Technical Literacy and Pedagogical Training}

The importance of the technical literacy of instructors in career academies can be significant, considering the influence that the adult experts exert on the development of students in situated learning (Vygotsky, 1986). Instructors are the link to the industry or career at the core of the career academy's theme, and as such, should be able to model the latest best practices in industry. Another vital function they fulfill is that of facilitator in leading students towards competitive and portable skills required by industry in the global marketplace. Equally important is their ability to use technical language to communicate with industry leaders as they interact in mentoring the career technical programs (Kemple \& ScottClayton, 2004). The use of educational technology available can make a 
difference in making today's classrooms highly effective. Professional development for today's teachers must include the integration of that technology into their curriculum and teaching practices.

\section{Information and Communication Technology Literacy}

Technical information is language, mathematical, and scientific information that is directly related to the core career path or theme. The ability to use technology for information gathering is a critical skill that may well determine the global competitiveness of today's workforce. Academy and CTE instructors must model the highest level of Information and Communication Technology literacy (ICT) skills to prepare students for today's job market. ICT is related to the use of computers and web-based tools necessary for survival in any technical career (Rhodes, 2003). Table 1 details the seven components of information and communication technology literacy (ETS, 2003).

Table 1:

Components of ICT Proficiency

\section{PROCESS DEFINITION}

Define Using ICT tools to identify and appropriately represent information need Access Knowing about and knowing how to collect and/or retrieve information Manage Organizing information into existing classification schemes Integrate Interpreting, summarizing, comparing and contrasting information using similar or different forms of representation

Evaluate Reflecting to make judgments about the quality, relevance, usefulness, or efficiency of information (Continued) 
PROCESS

DEFINITION

Create Generating new information and knowledge by adapting, applying, designing, inventing, or representing information

Communicate Conveying information and knowledge to various individuals and/or groups

Note. From Educational Testing Service (2003)

\section{Career Technical Education Accountability Requirements}

There are important skills necessary in almost every career field to communicate, access the resources needed, and conduct research through the use of technology and the Internet (Katz \& Smith Macklin, 2007). The Carl D. Perkins Career and Technical Education Act of 2006, known as Perkins IV, delineates six Core Indicators of Performance for CTE students: 1) academic attainment in challenging reading/language arts and mathematics; 2) technical skill attainment aligned with industry standards; 3 ) secondary school completion, as evidenced by a secondary school diploma, General Education Development certificate, or other State-recognized equivalent; 4) student graduation rates; 5) placement in postsecondary education or advanced training, military service, or employment; 6) nontraditional participation in or nontraditional completion of CTE programs that lead to non-traditional fields (Perkins, 2006). Since career academies are centered on CTE themes and instructional models, these same skills would be needed for student success in a career-themed curriculum. 


\section{State Certification Requirements for CTE Teachers}

Over the past one hundred years, CTE teachers have followed one of two pathways to obtain certification or licensure: completion of a traditional teacher training program, or alternative certification based on industry experience. Both programs seek to train teachers to be effective in the classroom, and to provide them with the skills necessary to fulfill the students' educational goals.

Traditional programs require completion of at least a bachelor's degree, and an appropriate teacher preparation program, depending on the CTE pathway. Teachers must also demonstrate proficiency in basic academic skills, teaching methodology, technical content, and ability to perform basic tasks. A test on the specific skills needed for the career or technical area may also be required (Zirkle, Martin, \& Mc Caslin, 2007). Teachers in the alternative certification programs are usually recruited from industry, with varying degrees of technical or professional experience. Depending on the program, a minimum of a high school or technical and vocational certificate is required, along with a teacher preparation program emphasizing pedagogical and classroom management skills (Zirkle, Martin, \& Mc Caslin, 2007). Both pathways to certification require a mentoring or teacher preparation program. Some states may require additional preparation, a portfolio, and/or a job offer from the school districts.

\section{The Academy Teacher as Industry Role Model}

Vygotsky's studies of children's development revealed that a child's identity develops in a sociocultural context (Werstch, 1985), "human learning 
presupposes a specific social nature and a process by which children grow into the intellectual life of those around them" (Vygotsky, 1978, p. 88). Social context can become an important factor in helping students assimilate the idiosyncrasies and social nuances surrounding their chosen career field. In this respect, the instructor's updated skills gain a special significance, as it is from their professional experience that the student glimpses a view of what the workplace has in store for them. Intersubjectivity, or the way groups of people share feelings about the world around them helps establish a common focus and foster mutual respect among student/teacher team members (Bonk \& Cunningham, 1998). In career academies, the instructor or academy leader becomes the facilitator of social interaction, modeling industry's best practices, much like the master in a formal apprenticeship (Kemple \& Scott-Clayton, 2004). It is important for instructors to model proficiency in utilizing industry's latest and most effective best practices.

Teachers in the $21^{\text {st }}$ century career academies need to have the skills that can place them at the head of the class, as facilitators of important workplace skills and role models for their students. Secretary of Education Arne Duncan expressed this perspective in a March 3, 2010 keynote speech at the Association of American Publishers Annual Meeting:

"In the 21st century, students must be fully engaged. This requires the use of technology tools and resources, involvement with interesting and relevant projects, and learning environmentsincluding online environments-that are supportive and safe.

In the 21st century, educators must be given and be prepared to use technology tools; they must be collaborators in learning- 
constantly seeking knowledge and acquiring new skills along with their students." (Duncan, 2010)

\section{Teacher Pedagogical Skills}

Pedagogical skills are important in every aspect of any educational program. Industry expertise, although specifically necessary in career technical subjects, cannot ensure that instructors will effectively transfer knowledge to their students (Dagget, 2004). Because many career technical instructors come directly from industry with alternative certification, it is best to insure that their instructional and classroom management skills are up to pedagogical standards. In Florida, these teachers may enter the classroom without traditional college pedagogical training, although they are required to complete specific requirements, depending on the district where they are employed. The Florida Alternative Certification Program or FACP, published online by the Florida Department of Education, is the official statewide plan approved by most districts.

Some of the options include successfully completing the ABCTE and Educator Preparation Institutes, or other programs approved by the state. All of the programs insure teachers are successful in the following areas: 1) classroom management; 2) entry level skills; 3) individualized training plans; 4) mentor and administrator support; 5) collaborative assistance from higher education partners; 6) training curriculum that targets the Florida educator accomplished practices; 7) summative assessment of educator accomplished practices; and 8) Florida professional education certification tests. Additional care may need to be employed in determining the needs for professional development required by 
career academy instructors with alternative certification (Alternative Certification in Florida, 2006).

\section{Student Achievement Standards}

The No Child Left Behind Act of 2001 is described by the $107^{\text {th }}$ Congress as "An Act to close the achievement gap with accountability, flexibility, and choice, so that no child is left behind" (United States of America, 107th Congress, 2002, p. 1). The legislation placed the onus of moving students forward on the schools and teachers by linking educational federal money to student academic success. As a result, educational assessment constitutes one of today's most contentious subjects of discussion among educators. In the State of Florida, students who do not place well on the FCAT are exposed to grade retention at the Grade 3 level, and not meeting the requirements to receive a standard diploma if they do not succeed in passing the FCAT at the Grade 10 level (Florida Department of Education, 2007).

The latest salvo launched at teachers by the Florida Legislature is the controversial SB 736 law, which ties student performance on the reading section of the Florida Comprehensive Assessment Test (FCAT) to teacher effectiveness and merit pay (Isensee, L., 2011). Teachers are evaluated using a complicated "value-added" formula that critics say does not take into consideration such factors as gender and socio-economic status. Another problematic issue is the fact that $60 \%$ of teachers do not work in subjects assessed by the FCAT. These teachers will be evaluated according to the scores their students make on the FCAT Reading Assessment, using the school-level scores to determine their 
effectiveness. That translates to teachers being evaluated according to what other teachers' effectiveness is in an entirely different subject and classroom as their own (Isensee, L, 2011).

The issue at hand is to measure student success with an objective and valid process, given the high-stakes nature involved for both educators and students. At the present time, the FCAT is the main evaluation tool used in Florida schools to determine student academic success. The only areas assessed are reading, writing, some mathematic subjects, history, and science. The FLDOE is working on implementing end-of-course tests in many other subjects, which would be more relevant in assessing student and teacher performance than the present standardized testing (FLDOE, 2011).

\section{Common Core State Standards}

Concerns for meeting global workforce standards has led the states to come up with a set of educational standards that can fully prepare our graduates to meet the rising expectations of the global workplace. As a result of intensive collaboration between teachers, administrators, curriculum and instructional experts, and industry leaders, several states in the United States created The Common Core Standards Initiative, with the vision to design and implement a set of world-class curriculum standards which meet the present challenge (Common Core Standards Initiative, 2012). The initiative is coordinated by the National Governors Association Center for Best Practices (NGA Center) and the Council of Chief State School Officers (CCSSO). 
The original draft was developed with voluntary participation from the states, including feedback from professional national organizations of teachers, postsecondary educators, English Language Learners teachers, and teachers of students with disabilities. Benchmarking modeling from highly successful programs across the country and from countries around the world was used to inform their development.

One of the important features of the new standards is that they were created with the end in mind: skills needed for students to be successful in college, a career, or in being productive and informed citizens of society. The skills scaffold, or staircase from year to year beginning in kindergarten and ending in graduation from high school. The emphasis is on what students can do or be able to do by the end of the year, in a seamless progression from K-12. Teachers are told what they need to teach...the methodology of how they teach is left up to teachers. Consistent curriculum across the states facilitates student portability of skills (Common Core Standards Initiative, 2012).

\section{Summary}

Career technical education has been at the forefront of training America's workforce to stay competitive for over one hundred years. The changes in technology and in manufacturing methods have been the wind that pushed the sails driving the curriculum and the classroom practices of career and technical programs. In many cases, instructional design and content were finely attuned to the needs of industry, with industry advisory committees providing input regarding the direction in which to set the course (Hake, 2010; Stone, 2002). 
Responding quickly to today's rapidly expanding global economy may prove to be career technical education's most important challenge. Many developing countries, with the help of the World Bank and major multi-national companies are investing greatly in training their workforce to compete for a piece of the action in what is now a boundless marketplace, limited only by the skills and bottom line value of available workers (Friedman, 2007). As job qualifications change in industry, flexibility in transferring and updating skills to meet the new requirements, as well as developing new skills, is the best assurance for workers to remain competitive and retain their employment (Thijssen, Van de Heijden, \& Rocco, 2008).

Career academies are a viable solution to a growing problem facing education. The skills required of today's workforce need to be embedded into every aspect of an individual's education, starting early in life (Hull, 2003). The complexity of today's workplace demands high-order thinking and communication skills, as well as knowledge of the most advanced technical systems and tools available. The integration of demanding academic skills with highly specialized technology training have proven to facilitate a special environment in which the child can develop in a meaningful way, while exploring future career interests and acquiring portable technological skills that can be applied to many areas of life (Bonk \& Cunningham, 1998; Bottoms \& Sharpe, 1996; Hake, 2010; Bray, Green, \& Kay, 2010).

John Dewey's visionary philosophy ascribed a child's meaningful experience in the school environment with the elements necessary for success in 
academic and vocational endeavors (Dewey, 1916). Lev Vygotsky further associated that success with the involvement of expert adult instructors and capable peers in providing help and scaffolding for a child's educational experience in a meaningful exchange of ideas (Vygotsky, 1978). Research in the last part of the $20^{\text {th }}$ century provided empirical evidence for what Dewey and Vygotsky proposed: students learn better in a contextually rich environment, with real-world projects adding relevance to an otherwise vacuous learning environment (Bottoms \& Sharpe, 1996; Daggett, 2004; Kemple \& Scott-Clayton, 2004; Pucel \& Sundre, 1999).

Career academy environments provide a nest in which intellects can be nourished and shaped into high-performing elements of a world-class workforce (Kemple \& Scott-Clayton, 2004). Proper caution needs to be exercised in the case of industry advisory boards or industry partnerships controlled by specific companies with their own agendas for shaping the workforce to address their own needs. The combination of high standards of academic performance and industry best practices may lead students to become highly competitive members of the global workforce. The guidance and warmth of a capable and involved mentor become a vital force for bringing the individual student into gestation, with the support of the appropriate tools and curriculum, to gain a foothold into an exciting future. 


\section{CHAPTER III}

METHOD

This chapter begins with the purpose of the study and the research questions as previously depicted in Chapter 1 . Next is a description of the research design, the population, sample, variables, and the instruments used to gather the data and examine the predictor variables. Following this is a discussion of the procedures for data collection, data organization, data protection, and data analysis. A summary of the methods and limitations of the study conclude this chapter.

\section{Purpose of the Study}

The purpose of this study was to examine the relationship between the level of technical literacy of instructors in career academies and students' academic performance.

The following four null hypotheses were formulated for this study:

1. There is not a positive relationship between the technical literacy of career academy instructors and the academic performance of career academy students.

2. There is not a positive relationship between the level of pedagogical experience of career academy instructors and the academic performance of career academy students.

3. After controlling for teacher attitudes toward technology integration, there is not a positive relationship between teacher technical literacy and student academic performance. 
4. After controlling for teacher attitudes toward technology integration, there is not a positive relationship between teacher pedagogical experience and student academic performance

\section{Research Design}

Because of the nature of the research questions, a nonexperimental, ex post facto quantitative research design was used. Ex post facto research designs are used in studies where the independent variables cannot be manipulated as they are in experimental designs. Ex post facto designs are especially useful for investigating possible associations between variables and group differences. Because ex post facto research does not allow for examining causal linkages among variables, generalizations to the general population should be made only most cautiously (Creswell, 2008; Montero \& Leon, 2007).

\section{Quantitative Research Design}

Quantitative studies often collect data via surveys and questionnaires, which have been shown to be useful research tools (Dillman, 2007; Hinkle \& Oliver, 1983). A description of the population and sample is presented, followed by a description of the predictor and dependent variables identified for the study, and procedures for selecting and evaluating the instruments used to measure them. A discussion follows regarding how the sites for collecting the data were chosen, a description of the gatekeepers and protocol followed in accessing the data, protection of participants, and how the data was collected, managed and analyzed. 


\section{Population and Sample}

The target population for this study was composed of career academy teachers and their students using one of sixteen career technical education (CTE) clusters as a common theme for curriculum and instruction (SSR, April 29, 2008). The accessible population was found in 49 senior high schools and technical education centers in the Miami-Dade County Public Schools (M-DCPS) that offer these programs.

\section{Career Academies}

Career Academies are a popular model of comprehensive secondary school reform, restructuring larger traditional high schools into small learning communities organized around one or more career paths or occupations (U.S. Department of Education, 2008). In most cases, students enter the program during Grade 9 and remain with the same cohort throughout their high school program. They have the same career academy teachers and counselors throughout the program. Teachers share common planning time and the curriculum is designed to integrate traditional academics with CTE goals and objectives. Academic collaboration across subject areas includes responsibility for the curriculum, instruction, evaluation, and discipline of students in groups of 100 to 150 . Many of these students begin technical courses of their choice at the secondary level, and transition on to post-secondary training in a technical center, college, university, or an apprenticeship to complete their studies (SSR, April 29, 2008). 
On March 16, 2005, the M-DCPS adopted the Advocacy Framework Model for Career Academies developed by the National High School Alliance, which includes six core principles: personalized learning environments; academic engagement of all students; empowered educators; accountable leaders; engaged community and youth; and integrated system of high standards, curriculum, instruction, assessment, \& support (SSR, April 29, 2008).

In 2006, the Florida Legislature defined career and professional academies in section 27-1003.493 of the A++ legislature as a "research-based program that integrates a rigorous academic curriculum with an industry-driven career curriculum" (Florida Legislature, 2006). The Miami-Dade County Public School system has been moving towards an all-career academy high school reform model for the past 20 years, and the Secondary School Reform plan is the latest attempt to implement the use of the career academy model in all of the district's high schools. At the time of this study, a total of 191 academies were operating in 49 M-DCPS senior high schools offering students a wide choice to design and follow through their secondary education within a desired career path. Another 13 academies operated in specialized or technical centers (SSR, 2008).

\section{Career Academy Instructors}

The staff for a career academy consists of academic and career field teachers, as well as counselors, an administrator, and other support personnel. Autonomous authority over the program is given to the cadre, and they function as an independent unit within the larger educational center. Academic teachers are normally recruited from traditional university teacher training programs, or 
from existing staff with academic certification in the areas of Language Arts/Reading, Math, Science, and Social Studies. Career field teachers may be recruited from CTE programs, or from industry and may obtain certification through Florida's Alternative Certification Program (Florida Department of Education, 2002).

\section{Sample}

The researcher was allowed access to six secondary schools' teachers from 42 academies that represent a diverse population across the Miami-Dade County Public Schools system. The names of teachers participating in career academy programs were obtained from the master schedule of each school. There were a total of 524 career academy teachers in the six target schools, most academies having roughly six teachers, with at least one career field teacher, several academic teachers, one counselor, and one administrator each. See Table 1 for a demographic description of the Miami-Dade County Public Schools.

In an effort to maximize the response rate, survey invitations were mailed to the entire population of 524 teachers, of whom 136 responded. Of the 136 teachers responding to the survey, 115 did not have learning gains data for the previous year, mostly due to the composition of their student population and the fact that they did not have the same students two years in a row as is common in secondary career academy cadres (Kemple \& Scott-Clayton, 2004). The MDCPS is a very large urban school system with an highly fluctuating population of immigrants. This makes it very difficult to track and associate student 
performance to a specific teacher, making it equally difficult to hold teachers accountable for specific students' learning gains and academic progress. More research needs to be conducted in this area if the Florida Department of Education insists in making teachers accountable for student progress.

Many of these teachers were also assigned to areas that did not associate them with students testing in reading that year as their learning gains were reported through their reading/language arts classes. However, the demographic data obtained from all teachers taking the survey were examined to determine if there was evidence of disproportional representation by gender and race/ethnicity between the 21 final participants in this research, the remaining 115 teachers with incomplete data sets, and the district-level teacher representation by gender and race/ethnicity (see Table 2 ).

Table 2

Gender and Racial/Ethnic Demographic Characteristics of Secondary Instructors

\begin{tabular}{llll}
\hline \multicolumn{1}{c}{ Characteristic } & $\begin{array}{l}\text { Miami-Dade } \\
\text { District }\end{array}$ & $\begin{array}{l}\text { Participants' } \\
\text { Complete Data }\end{array}$ & $\begin{array}{l}\text { Participants' } \\
\text { Missing Data }\end{array}$ \\
\hline $\begin{array}{llll}\text { Gender } \\
\text { Male }\end{array}$ & $2744(38.1 \%)$ & $2(9.5 \%)$ & $44(38.3 \%)$ \\
Female & $4452(61.9 \%)$ & $19(90.5 \%)$ & $71(61.7 \%)$ \\
Race/Ethnicity & & & \\
White & $2375(33.0 \%)$ & $5(23.8 \%)$ & $39(33.9 \%)$ \\
Black & $1820(25.3 \%)$ & $3(14.3 \%)$ & $21(18.3 \%)$ \\
Hispanic & $2842(39.5 \%)$ & $12(57.1 \%)$ & $52(45.2 \%)$ \\
American Indian & $41(0.6 \%)$ & $0(0.0 \%)$ & $0(0.0 \%)$ \\
Asian/Other & $118(1.6 \%)$ & $1(4.8 \%)$ & $3(2.6 \%)$ \\
Total & 7196 & 21 & 115 \\
\hline Note. From Florida Department of Education Staff Information Database $(2010) ;{ }^{*}=$ \\
missing learning gains data.
\end{tabular}




\section{Target School Descriptions}

The Florida Legislature enacted a law in 1991 requiring schools to establish School Advisory Councils responsible for developing School Improvement Plans. In 1996, the School Board of Dade County, Florida, in agreement with the teachers' union, created the Educational Excellence School Advisory Councils (EESAC) for that purpose (School Board, 1996). Additionally, the EESAC committee helps assistant principals develop the school's budget and serves as a liaison with all stakeholders in guiding the school's future direction. School Improvement Plans are only final when approved by the M-DCPS School Board. The following information was obtained from the School Improvement Plans for each of the six participating schools, which contain annually updated historical, demographic, and student performance data (School Board, 2009). American Senior High serves a mostly Hispanic population $(65 \%, n=$ $1,743)$, with students coming from a variety of economic backgrounds ranging from very affluent, to working middle class. Most of the students come from the surrounding neighborhood, composed of affluent, and upper middle class families. Black students comprise the next largest subgroup $(27 \%, n=724)$, coming from nearby Miami Gardens, and ranging in economic background from upper middle class to working middle class. Other groups are White $(5 \%, n=$ $134)$ and Asian ( $3 \%, n=81)$, coming mostly from the affluent surrounding neighborhoods. Total student population is 2,682 . The school is divided into small learning communities, or career academies, which include the Academy of Biomedical Careers, Academy of Hospitality and Tourism, Academy of 
Information Technology, Engineering Academy for Student Excellence, Fine Arts Academy, Law Studies Academy, and the Undergraduate Studies Academy. The entire instructional staff at American Senior participates in the career academies, making up a total of 114 career technical and academic teachers.

Hialeah Senior High serves a mostly Hispanic population in a lower middle class neighborhood. The total student population is 3,450 , with $90 \%(n=3,105)$ Hispanic, $7 \%(n=242)$ Black, $2 \%(n=69)$ White, and less than $1 \%(n=35)$ Asian, American Indian, or multi-racial. The school demographics reflect the nature of the neighborhood, with a large number of new immigrants. The student population includes $17.8 \%$ English Language Learners (ELL), and 6.9\% Special Education (SPED) students. Hialeah Senior High is organized into twelve academies: Visual \& Performing Arts; Communications \& Digital Technology; Medical \& Health Science; Culinary Arts; Marketing \& Retail Services; Business \& Information Technology; Education; Transportation; Engineering, Construction, Science \& Math; Small Business \& Entrepreneurship; Global Studies \& World Languages; and Legal \& Public Services. A total of 83 career technical and academic teachers are assigned to the academies.

Miami Carol City Senior High is located in Miami Gardens, a newly incorporated city in the Northwest section of the county. Sixty-three percent of the students come from a very low socio-economic status. A large percent of the students are Black $(87 \%, n=1,686)$, with Hispanics comprising $10 \%(n=194)$ of the population, $4 \%(n=78)$ of White, and only .7\% $(n=14)$ of Asian, Native Americans and Others making up the rest. Present enrolment is 1,938 students. 
The school's high mobility rate (34\%) negatively affects the funding of the programs, and the number of teachers on staff. The academies at Miami Carol City Senior are divided into five themes or career paths: Business \& Information Technology; Industrial Technology \& Personal Services; Visual \& Performing Arts; Health Science \& Medicine; and Legal, Public Safety, Corrections, \& Security. This last career path has recently added a Criminal Justice strand, sponsored by the I Choose Grant; it is described as a high profile Magnet Program. A total of 103 academic and career technical teachers participate in all the career academies.

Barbara Goleman Senior High opened in 1995 while still under construction. Only $10^{\text {th }}$ graders were enrolled during the first year, and more grades were added in subsequent school years as the facilities were being finished. An innovative educational program was developed under the leadership of an elite staff using the Audrey Cohen College System of Education. Purposecentered activities were at the core of the program, and students were encouraged to work in interdisciplinary teams to complete meaningful community based projects. Because of its location in Miami Lakes, the student population was largely derived from upper middle class Hispanic families. A small population of Black and White Non-Hispanic students remained stable throughout the years. The population grew from 1,790 students in 1995 , to its peak of 4,649 students in 2002, largely because of growth in the Hispanic population in the area. During the first year, Hispanics comprised $87 \%(n=1,562)$ of the population, Blacks $8 \%$ $(n=137)$, White $4 \%(n=78)$ and Other $1 \%(n=13)$. At its peak Hispanics 
comprised $93 \%(n=4,320)$ of the population, Blacks $2 \%(n=98)$, White $4 \%(n=$ 197), and Other .7\% $(n=34)$. By the 2010-2011school year, the opening of several other schools in the area caused a large drop in the population to a total of 1972 , nearly its lowest historic level. Hispanics now comprise $84 \%(n=1,656)$ of the population, Blacks $7 \%(n=138)$, White $8 \%(n=158)$, and other $1 \%(n=$ 20). Many of the original innovative programs have been abandoned resulting in fewer choices for students and a reduction in staff. The school qualifies for Title I funding due to a significant percentage of the student population (54\%) being considered as Economically Disadvantaged. The school offers five different career academies: International Finance and Business, Education, Architectural Drafting, Health Science and Medicine, and Insurance. As part of a Small Learning Communities grant, ninth grade students participate in interdisciplinary academic teams.

Miami Lakes Educational Center opened in 1976 as a post secondary training center, and a secondary program was added in the year 2000 . The secondary program has a population of 1,600 students, with $80 \%(n=1,280)$ Hispanic, 14\% $(n=224)$ Black, 4\% $(n=64)$ White, and 2\% $(n=32)$ Asian, Native American, and Other. The school qualifies for Title I funding due to a significant percentage of the student population (60\%) being considered as Economically Disadvantaged. Additionally, $9 \%$ are Students with Disabilities, $14 \%$ are Gifted, and $3 \%$ are English Language Learners. The secondary program is divided into five small learning communities, or career academies: Cambridge Academy; Communications \& Entertainment Academy; Entrepreneurship Academy; 
Information Technology Academy; and the Health Academy. Fourteen Advanced Placement courses and six Advanced International Certificate of Education courses are also offered. A total of 88 academic and career technical teachers participate in the five academies.

Originally designated a School of Choice, students at William H. Turner Technical Arts High School are chosen from the community to participate in career academies of their choice. Since its inception in 1993, Turner Tech, as the school became known, was designed to support the school's vision of preparing urban students with training in $21^{\text {st }}$ century academic and vocational skills to compete in a global marketplace. The building's architecture and technical facilities were structured around the small learning communities' concept, with emphasis on state-of-the-art career technical labs and common planning areas. The school was meant to be a showcase of the career academy model of secondary school reform. As an early model of school reform, Turner Tech supports the principles of the Southern Regional Education Board's High Schools That Work program, and the Coalition of Essential Schools. These principles suggest that an effective school requires that all stakeholders work together towards a common goal in a collaborative setting. The school serves a population of 1,745 students, with $27 \%(n=471)$ Hispanic, $71 \%(n=1,239)$ Black, $1 \%(n=17)$ White, and 1\% $(n=17)$ Asian, Native American, and Other. There are seven career academies to choose from at Turner Tech including Agriscience, Construction Management, Architectural Technology, Finance, Health, Public Service, and Information Technology/Entrepreneurship. There are 
a total of 79 academic and career technical teachers working in the career academies at William H. Turner Senior.

Table 3

Racial/Ethnic Composition of Career Academy Students by School

\begin{tabular}{llccccc}
\hline Characteristic & $\begin{array}{c}\text { American } \\
\text { Senior }\end{array}$ & $\begin{array}{c}\text { Carol } \\
\text { City }\end{array}$ & $\begin{array}{c}\text { Barbara } \\
\text { Goleman }\end{array}$ & $\begin{array}{c}\text { Hialeah } \\
\text { Senior }\end{array}$ & $\begin{array}{c}\text { Miami } \\
\text { Lakes }\end{array}$ & $\begin{array}{c}\text { William } \\
\text { Turner }\end{array}$ \\
\hline Race/Ethnicity & & & & & & \\
White & 134 & 76 & 158 & 69 & 64 & 19 \\
Black & 724 & 1686 & 138 & 242 & 224 & 1236 \\
Hispanic & 1743 & 194 & 1656 & 3105 & 80 & 464 \\
Asian/Other & 81 & 19 & 20 & 34 & 1280 & 26 \\
Total & 2682 & 1975 & 1972 & 3450 & 1600 & 1745 \\
\hline
\end{tabular}

Note. From Miami Dade County Public Schools Information Clearinghouse (2013)

\section{Research Variables}

Teacher technology standards developed by the Florida Department of Education's Office of Technology Learning and Innovation (OTLI, 2008) were used to guide selecting the following three independent variables that represent technical literacy: Teacher Confidence Using Computers, Teachers' Comfort Level in Using Computers, and Teachers' Expertise in Integrating Computers into the Curriculum. Confidence, comfort, and expertise have also been associated positively with technical competency in prior research (Reio \& Sutton, 2006). Teachers' Attitudes Toward Computer Use was also used as an independent 
variable as attitudes have been shown to be significant predictors of behavior above and beyond perceptions, personality traits and cognitive ability (Robbins \& Judge, 2013). The first independent variable, teacher confidence using computers, relates to the use of computers by teachers as a tool for instruction in the classroom. The second independent variable is teachers' comfort level in using computers as a tool in classroom instruction, and the third independent variable is teachers' expertise in integrating computers into the curriculum, including how students use technology activities in the classroom. The fourth independent variable is teachers' attitudes toward computer use. Attitude towards computers is an important factor in influencing classroom technology integration by instructors (Christensen \& Knezek, 1996).

The data for the four independent variables was collected using the Teachers' Attitudes Toward Computers Questionnaire (TAC; Christensen \& Knezek, 1996). The literature indicates that teachers who demonstrate greater confidence using computers, reveal more comfort using computers as a teaching tool, and display greater technical expertise in integrating computers in the curriculum are technically proficient (Christensen \& Knezek, 1996; OTLI, 2008). In addition, those teachers who exhibit more positive attitudes toward computer use will be more likely to use computers in the classroom.

Pedagogical experience was measured by asking the respondent to indicate the number of years of experience he or she had in integrating technology into the classroom. 
The dependent variable was student academic performance as indicated by their percent learning gains in achieving Florida's Sunshine State Standards (SSS), measured by the reading section of the Florida Comprehensive Achievement Test (FLDOE, 2007). The data was retrieved from archival data kept by the M-DCPS District Office of Data and Assessment.

\section{Instruments}

\section{Teacher Technical Literacy and Attitudes Toward Computer Use}

A modified version of the Teachers' Attitudes Toward Computers Questionnaire (TAC) was used to measure technical literacy, which included four scales: (a) teacher confidence and comfort using computers to teach (global), (b) confidence using specific technologies (e.g., design and create a web page), and (c) technical expertise integrating technology and computers into the classroom (Christensen \& Knezek, 2009). Attitudes toward technology use were also measured with this instrument. The original TAC was modeled after 14 validated computer attitude survey instruments and consisted of 284 items. Christensen and Knezek conducted extensive administration of a battery of the14 tests and selected the best items to construct a shorter version consisting of 52 items (1996). The researcher added demographic items to the survey: gender, race or ethnicity, education, teaching experience, experience in career areas, grade levels and subject areas taught, pedagogical training, technology training, average number of students in a class, number of computers available for student use, student access to computers, connectivity to the Internet, and years of experience in integrating computers into the curriculum. 
The additional items for this study's survey were created using Dillman's (2007) guidelines, and were field-tested on a smaller teacher sample $(N=12)$ where slight adjustment was made to the instructions for clarification purposes before using it with the target population.

The first section of this study's survey, "About You" consists of 11 demographic items, including gender, race or ethnicity, highest degree earned, total teaching experience, number of years of experience in career areas, grade levels and subject areas taught, pedagogical training, technology training, average number of students in a class, number of computers available for student use, number of hours students have access to computers, and number of years experience in integrating computers into the curriculum. Each demographic item had been linked by researchers to teachers' technology use in the classroom.

In the second to fourth sections, each of the items employed a 5-point Likert scale ranging from 1 "strongly disagree" to 5 "strongly agree." In the fifth, a 5-point Likert scale was used ranging from 1 "not at all" to 5 "every day." A sample item from this teacher expertise with integrating technology in the classroom scale was "I use multimedia presentations to introduce learning activities to students." This scale differed from the aforementioned three because it measured frequency of technology integration. Overall scores for each scale were obtained by adding the items. The second section, "Confidence and Comfort Using Computers", consisted of eight items. The third section, "Attitudes Towards Computer Use", consisted of 21 items while the fourth section, "Teacher 
Confidence Level", also consisted of 21 items. Section five, "Integration of Computers Into the Classroom", consisted of 32 items. Table 4 provides a sample of the items for two of the three technical literacy scales and the attitudes scale.

Table 4

Sample Items on Teacher's Attitudes Toward Computers Questionnaire: Sections 2-4*

Instructions: Select one level of agreement for each statement to indicate how you feel.

(1) SD = Strongly Disagree, (2) D = Disagree, (3) U = Undecided, (4) A = Agree,

(5) $\mathbf{S A}=$ Strongly Agree

1. The computer enhances my teaching. (Confidence and Comfort Using Computers)

2. Computer skills are essential to my students. (Attitudes Towards Computer Use)

3. I am confident that I can: Create a presentation on the computer. (Teacher Confidence)

Note. ${ }^{*}=$ See Appendix A for a more detailed, final version of the complete survey.

\section{Pedagogical Experience}

Career academy teachers' pedagogical experience was measured by asking "How many years have you been using computers in your classroom for instruction?"

\section{Percent Learning Gains}

The dependent variable, learning gains percentage in academic performance of career academy students per teacher, was determined using scores from the Florida Comprehensive Assessment Test (FCAT) reading section. The FCAT is a criterion-based high-stakes assessment used since 1996 
by the Florida Department of Education to determine student academic progress and school accountability (FLDOE, 2004).

Computing percent learning gains. Percent learning gains by teacher were determined according to the number of their students making learning gains using a formula developed by the Florida Department of Education (FDOE, 2012). The students' FCAT Reading scores from 2011 were compared with the 2012 scores. Florida Alternate Assessment (FAA) scores were used for students with significant cognitive disabilities not taking the FCAT. Learning gains are achieved if the student (a) improves one or more achievement levels on the FCAT 2 or FAA, (b) maintains a proficiency level of at least 3 on the FCAT, or 4 for the FAA without decreasing a level, or (c) demonstrates more than one year's equivalent of learning growth (see Appendix B for more detailed description). FCAT Development and Validation.

In 1999, the Florida Legislature enacted legislation known as the A+ Plan for education. The standards for accountability were increased, and school performance grades were issued based on their students' results on their reading, mathematics, and science sections of the assessment. Academic performance of career academy students was measured using their scores on the reading section of the Florida Comprehensive Assessment Test. The FCAT was first adopted in 1998 as the official assessment instrument of academic success for students in Florida (FLDOE, 2004).

Description. The FCAT is used to measure student achievement of the Sunshine State Standards developed by the FLDOE. The test consists of annual 
criterion-referenced tests in reading and mathematics for Grades 3 through 10. Writing is assessed in Grades 4, 8, and 10; science assessments are given in Grades 5, 8, and 11 (Florida House of Representatives, 2010). Beginning in 2010, End of Course Assessments in Algebra, Geometry, Biology, and U.S. History will be phased-in to replace the FCAT. On April 2011 the new FCAT2 Assessment, based on the New Generation Sunshine States Standards (NGSSS) benchmarks, was used to assess the Reading section for Grades 3-10, and the Mathematics section for grades 3-8. The Mathematics section for students in grades 9-10 was given using the original Sunshine States Standards (SSS) adopted in 2007 (FLDOE, 2011).

Students taking the FCAT and the FCAT2 are scored on a scale of 1 to 5 on each assessment. Students in Grade 3 must obtain a Level 2 score or higher and complete academic requirements to be promoted to the fourth grade. A Level 3 score is considered to be at grade level, and Levels 4 and 5 above grade level. Grade 10 students must obtain a scale score of 300 or higher in the Reading, Writing+, and Math sections and complete academic requirements to be able to graduate with a regular diploma. Students are allowed to retake the assessment up to six times in Grades 11 and 12 (FLDOE, 2007). Figures 1 and 2 show scores students at each grade level needed to attain to reach the various achievement levels in the Spring 2011 Reading and Mathematics sections of the FCAT. 
${ }^{*}$ Figure 1

Achievement Levels for the FCAT Reading Equivalent Scores

\begin{tabular}{|c|c|c|c|c|c|}
\hline Grade & Level 1 & Level 2 & Level 3 & Level 4 & Level 5 \\
\hline 3 & $86-1045$ & $1046-1197$ & $1198-1488$ & $1489-1865$ & $1866-2514$ \\
\hline 4 & $295-1314$ & $1315-1455$ & $1456-1689$ & $1690-1964$ & $1965-2638$ \\
\hline 5 & $474-1341$ & $1342-1509$ & $1510-1761$ & $1762-2058$ & $2059-2713$ \\
\hline 6 & $539-1449$ & $1450-1621$ & $1622-1859$ & $1860-2125$ & $2126-2758$ \\
\hline 7 & $671-1541$ & $1542-1714$ & $1715-1944$ & $1945-2180$ & $2181-2767$ \\
\hline 8 & $886-1695$ & $1696-1881$ & $1882-2072$ & $2073-2281$ & $2282-2790$ \\
\hline 9 & $772-1771$ & $1772-1971$ & $1972-2145$ & $2146-2297$ & $2298-2943$ \\
\hline 10 & $844-1851$ & $1852-2067$ & $2068-2218$ & $2219-2310$ & $2311-3008$ \\
\hline
\end{tabular}

${ }^{*}$ Figure 2

Achievement Levels for the FCAT Mathematics Equivalent Scores

\begin{tabular}{|c|c|c|c|c|c|}
\hline Grade & Level 1 & Level 2 & Level 3 & Level 4 & Level 5 \\
\hline 3 & $375-1078$ & $1079-1268$ & $1269-1508$ & $1509-1749$ & $1750-2225$ \\
\hline 4 & $581-1276$ & $1277-1443$ & $1444-1657$ & $1658-1862$ & $1863-2330$ \\
\hline 5 & $569-1451$ & $1452-1631$ & $1632-1768$ & $1769-1956$ & $1957-2456$ \\
\hline 6 & $770-1553$ & $1554-1691$ & $1692-1859$ & $1860-2018$ & $2019-2492$ \\
\hline 7 & $958-1660$ & $1661-1785$ & $1786-1938$ & $1939-2079$ & $2080-2572$ \\
\hline 8 & $1025-1732$ & $1733-1850$ & $1851-1997$ & $1998-2091$ & $2092-2605$ \\
\hline
\end{tabular}

*Note: Tables 4 and 5 are reproduced from the Florida Department of Education's Office of Assessment 2011 FCAT Fact Sheet (FLDOE 2011).

Reliability and validity of the FCAT. The high-stakes nature of the FCAT demands a complex and redundant process for developing, administering, scoring, and reporting student performance data. The present version of the FCAT was developed and is administered by the FLDOE in collaboration with Pearson, a comprehensive provider of educational products. Quality assurance 
for the FCAT involves several of Pearson's interdisciplinary teams in an annual multi-stage validation process. Four categories make up this process: 1) test development, 2) test processing and scoring, 3) psychometric analysis, and 4) score reporting (Pearson, 2010). Content experts take every test to verify the answers are correctly printed and coded. The Assessment and Information Quality team validates machine scoring and management of data independently. Doctoral level psychometricians rescore multiple-choice items, ensuring that their answers match the machine-scored items. Pearson uses HumRRO, an independent contractor, to conduct further psychometrics analyses (FDOE, 2007). Additionally, outside auditors are charged with the task of examining the tests to provide feedback on test items and testing procedures (Buros, 2007).

Besides Pearson's teams, at least two oversight bodies ensure the reliability and validity of the assessment. One is made up of individual school district personnel, and the other is a Technical Advisory Committee composed of experts who review the test items and annual scores (FDOE, 2007).

Reliability in testing is a measure of consistency in assessing a student's knowledge. The four coefficients of reliability measured in the FCAT are a) internal consistency, b) test-retest reliability, c) inter-rater reliability, and d) reliability of classifications. Tests for reliability on the 2005 and 2006 FCAT SSS administration of reading and mathematics assessments using Cronbach's Alpha demonstrated that the coefficients of reliability were between 0.85 and 0.90 . Tests using the KR-20 formula on the 2005-2006 NRT administration of reading and math sections returned coefficients between 0.87 and 0.92 . The coefficient 
value can be a number from 0.0 to 1.0 , with 1.0 being a perfectly consistent reliability. The reliability of both the FCAT and the NRT assessments can, therefore be considered to be very high (FLDOE, 2007).

\section{Data Collection Procedures}

The following discussion presents the process of securing appropriate permissions to conduct a research survey, the data collection process, and the FCAT archival data collection. The process of contacting the gatekeepers to secure the archival data collected on learning gains from the FCAT is also discussed.

\section{Protection of Participants}

Prior to collecting any data or contacting any of the participants, permission to conduct human research was secured from the Florida International University Institutional Review Board and the College of Education Office of Graduate Studies. Once permission to conduct the study was secured, a copy of the study proposal and the appropriate application to collect data was sent to the Director of General Education Evaluation and Research in the Office of Program Evaluation at the M-DCPS District Office. This office approves any data collection or access to information in the school system.

Once permission to collect data was granted from FIU's IRB and the M-

DCPS District office and consent was given by the schools' principal to conduct school site data collection, participants were recruited on a strictly voluntary basis. The first contact was a letter distributed through school mail to selected teachers describing the nature, importance, and purpose of the survey. They 
were also informed of the benefits and risks involved, and the fact that they could choose to leave the project at any time without being penalized in any way. Participants were reassured that their identity and personal data would remain strictly confidential, and that any personal data collected would only be accessed by the researcher, and reported only in a group form. The researcher's contact information was made available in the event participants should have any questions or concerns. As an incentive to participate, teachers answering the survey were invited to attend a complimentary professional development session with the opportunity to earn professional development points. No compensation was given otherwise, and the reward was not contingent upon the results of the survey.

Survey Gold identified the participants using a number known only to the researcher. Information from the completed surveys was received automatically in a separate secure electronic mail account set up for that purpose, and the data were transferred to a secure computer drive only accessible to the researcher. The computer was kept in a secure location under lock and key. Data from the survey will be kept for 6 years after completion of the study, and destroyed at that time.

\section{Instrument Administration}

The survey was administered to participating teachers beginning in September 2011. The chosen method of administration was via an online survey. FCAT archival data on learning gains were obtained from the Research and Data 
Analysis Office database, with the cooperation of an administrative director of the M-DCPS.

Survey data collection. Dillman (2007) identifies four sources of survey error: sampling error, coverage error, measurement error, and nonresponse error. Sampling error occurs when some and not all members of the population are involved. This was minimized by attempting to include as many of the teachers as possible in all of the career academies at the six schools. Coverage error is the most common when conducting web surveys because of the limitations involving access to computers and the Internet (De Leeuw, Hox \& Dillman, 2008). This problem is less critical when it involves a specialized group of professionals with access to the technology (Dillman, 2007), as was the case in this study. Measurement error results from participants not being clear about the terminology used, or in the answers being vague or subject to interpretation. The TAC is composed of items with clear and concise choices given to the participant by means of using simple radio buttons. Finally, nonresponse error is where the results are weighing in favor of people who respond. Using a mixed approach to data collection, e.g., by giving respondents different choices or means to provide the data, helps to minimize this issue (De Leeuw, Hox \& Dillman, 2008). Thus, following Dillman's guidelines, every effort was made to reduce the four sources of survey error.

Moreover, the employee numbers of the participants were entered into a Microsoft Excel database, and the random number feature of Excel was used to 
generate a unique identifier number, which provided participants with a measure of confidentiality.

Dillman (2007) suggests that responding to self-administered surveys is a form of social exchange. The prospective respondent balances the cost of answering the questions with the perceived likelihood of social reward. Cost can be perceived as a combination of factors, such as time spent in completing the survey, the complexity of the questions, the inconvenience of providing personal information, or the lack of trust in the researchers or the institution they represent. The guarantee of keeping personal data confidential and proper protection of the data can make the participants feel better about providing accurate responses and increase the response rate (Dillman, 2007).

Prior to contacting teachers to collect the data, a meeting was set up with career academy leaders and administrators at each school to discuss the data collection and scope of the study. The unique nature of career academies was considered in developing the demographic questions so that the response rate and accuracy were maximized. Dillman's tailored design method of mail and Internet survey administration was used to construct the additional survey questions, design the questionnaire, and develop procedures for contacting teachers and collecting the data (Dillman, 2007). Internet survey was the preferred mode of collecting the teacher attitude and demographic data. The survey was administered using Survey Gold, which is the same type of online survey software often used by the M-DCPS to collect data. This increased the familiarity participants may have had with the survey format. 
Following the preliminary meetings with administrators and after obtaining permission to conduct data collection at the site (see Table 5), an introductory letter was placed in every teacher's school mailbox (see Appendix C). Three days later, an electronic mail message with specific instructions and a link to the online survey was sent to the potential participants. Teachers were given the option to request a paper-and-pencil version if so desired; none requested this option. An added benefit was to develop a trust and value factor that encourages response (Dillman, 2007). Teachers still not responding were sent a second courtesy reminder accompanying the survey link by school electronic mail after two weeks, emphasizing the importance of participation. A tracking tool designed with Microsoft Excel was created to maintain control of teacher responses and communications events.

In response to low teacher participation from the first two administrations of the survey, school administrators were contacted by the researcher a second time by email and telephone to request their cooperation. Three of the principals re-sent the survey web link to all their teachers encouraging participation. The researcher re-sent the survey also to those at the remaining three schools. Additionally, the researcher spoke on the phone or in person to teachers at three of the schools to request cooperation. After another two weeks, a fourth and final email with accompanying survey was sent to teachers who had not yet responded. 
Table 5

Data Collection Timeline and Tasks

\begin{tabular}{|c|c|}
\hline Time & Task \\
\hline $1^{\text {st }}$ Week & $\begin{array}{l}\text { Registration with Golden Hills, SurveyGold } \\
\text { provider of online survey } \\
\text { Survey uploaded to website } \\
\text { Creation of dedicated Gmail account for data }\end{array}$ \\
\hline $2^{\text {nd }}$ Week & $\begin{array}{l}\text { Email and telephone contact with school site } \\
\text { administrators to request permission to collect } \\
\text { data. }\end{array}$ \\
\hline $2^{\text {nd }}$ Week & $\begin{array}{l}\text { Pilot testing of online survey and SurveyGold } \\
\text { link }\end{array}$ \\
\hline $4^{\text {th }}$ Week & $\begin{array}{l}\text { First letter sent to teachers by school mail } \\
\text { requesting their participation in the online } \\
\text { survey }\end{array}$ \\
\hline $4^{\text {th }}$ Week & $\begin{array}{l}\text { First email to teachers requesting their } \\
\text { cooperation, including a link to the online } \\
\text { survey }\end{array}$ \\
\hline $6^{\text {th }}$ Week & $\begin{array}{l}\text { Second email and telephone contact with } \\
\text { career academy leaders and administrators } \\
\text { requesting their help to increase teacher } \\
\text { participation }\end{array}$ \\
\hline $8^{\text {th }}$ Week & $\begin{array}{l}\text { Second email to teachers requesting their } \\
\text { cooperation, including a link to the online } \\
\text { survey }\end{array}$ \\
\hline $12^{\text {th }}$ Week & $\begin{array}{l}\text { Third email, in-person appeals, and telephone } \\
\text { conversations to teachers still not responding }\end{array}$ \\
\hline $14^{\text {th }}$ Week & $\begin{array}{l}\text { Final email to teachers thanking participants } \\
\text { and exhorting non-participants to cooperate }\end{array}$ \\
\hline Throughout study & $\begin{array}{l}\text { Microsoft Excel database maintained by the } \\
\text { researcher to track responding teachers }\end{array}$ \\
\hline
\end{tabular}




\section{Data Analysis}

Existing FCAT student score data was retrieved from the M-DCPS District database into a Microsoft EXCEL database. An Administrative Director of Assessment Research, and Data Analysis in the M-DCPS District Office provided the District's data for FCAT learning gains in a Microsoft Excel file. Because not every teacher had learning gains data from the previous year, only 21 teachers from the original 136 survey respondents qualified to participate in the study. The data was analyzed using IBM SPSS 19 software package (IBM SPSS, 2010). Demographic and attitudinal survey data for teachers were also coded, classified, and analyzed.

Zero-order correlation analysis was utilized first to examine the strengths and directions of relationships among the research variables. One-way ANOVAs were used to investigate possible group differences and a two-way ANOVA was used next to test for possible variable interactions. Linear regressions were subsequently employed in the first two research questions to test the degree to which the independent variables predicted the dependent variable (percent student learning gains). To answer research questions three and four, a hierarchical regression was conducted to predict student learning gains percentage after statistically controlling for teacher attitudes toward technology. The hierarchical regression approach, which is theory and research guided (Cohen \& Cohen, 1983), allows the researcher to predict the unique contribution of the independent variables to the respective regression equations. Demographic data of the 21 participants and the remaining 115 respondents with 
incomplete data were analyzed to determine if there was disproportional representation by gender and race/ethnicity. The data was also compared to district-wide demographic data.

\section{Data Management}

All names, employee numbers, demographic and other data were encoded using random numbers identifiable only to the researcher. Survey responses were sent automatically to a secure email account created specifically for that purpose and accessible only to the researcher. Completed surveys were also stored in a secure SurveyGold database file residing inside a hard drive under lock and key and only accessible to the researcher. The data from the surveys were analyzed using SPSS and the results saved under the same guarded conditions. All files containing secure data from the study will continue to be kept under guarded conditions by the researcher for 6 years from the conclusion of the study (Florida International University, 2007)

\section{Summary}

Chapter 3 detailed the research processes including the research design, population and sampling, variables, instruments used, and procedures for data collection and analysis. The primary data sources were an expanded version of the Teachers' Attitudes Toward Computers Questionnaire, including demographic questions, and results from the 2010 and 2011 FCAT reading sections for student academic learning gains data. The participants' overall performance was collected from existing data warehoused by the M-DCPS Office of Program Evaluation. The Teachers' Attitudes Toward Computers 
Questionnaire was used to collect teacher demographic and technical literacy data.

Chapter 4 presents the findings of the study, and Chapter 5 concludes the study with a summary, implications, and recommendations for future research. 


\section{CHAPTER IV}

\section{RESULTS}

The purpose of this study was to examine the relationship between the level of technical literacy of instructors in career academies and students' academic performance. A nonexperimental, ex post facto quantitative research design was used, as described in Chapter 3. Correlational analysis was used to investigate the strength and direction of relationships among the research variables. One-way and two-way ANOVAs were employed to test for group differences. Linear and hierarchical regression statistical procedures were used to examine combined relationships of multiple independent variables with a single dependent variable, that is, percent student learning gains (Creswell, 2002). Teachers' technological literacy, attitudes toward technology, pedagogical experience or training, and other demographic data were collected using an expanded version of the Teachers' Attitudes Toward Computers Questionnaire (TAC). Four research questions directed this study.

This chapter presents the results of the study in three distinct sections: descriptions of the sample, examination of the research questions, and a summary of the chapter. Four null hypotheses were tested:

1. There is not a positive relationship between the technical literacy of career academy instructors and the academic performance of career academy students. 
2. There is not a positive relationship between the level of pedagogical experience of career academy instructors and the academic performance of career academy students.

3. After controlling for teacher attitudes toward technology integration, there is not a positive relationship between teacher technical literacy and student academic performance.

4. After controlling for teacher attitudes toward technology integration, there is not a positive relationship between teacher pedagogical experience and student academic performance

A linear regression was conducted to test hypothesis one, where the dependent variable student academic performance, operationalized as percent student learning gains, was regressed on the independent variable teacher technical expertise to predict the dependent variable. Likewise, to test hypothesis two, a linear regression was conducted where percent student learning gains was regressed on experience in integrating computers into the curriculum. For hypotheses three and four, hierarchical regressions were employed to test the hypotheses. The order of steps in a hierarchical regression analysis is decidedly guided by theory and research (Cohen \& Cohen, 1983). For hypothesis three, then, a hierarchical regression was conducted where teacher attitude towards computers was used as a control variable (first step in analysis) and subsequently teacher technical expertise (step two) was used to predict unique variance in percent student learning gains, the dependent variable. Finally, to test hypothesis four, a hierarchical regression was conducted where teacher attitude 
towards computers was used as a control variable (first step) and next, experience in integrating computers into the curriculum (second step) was used to predict unique variance in percent student learning gains.

\section{Demographic Characteristics of the Sample}

One hundred and thirty-six teacher respondents participated in a survey for this study, which represented $26.0 \%(N=524)$ of the population of teachers in the six schools surveyed. Because not every teacher had learning gains data from the previous year, only 21 teachers qualified to participate in the current study, despite surveying the entire population of teachers in the six schools as planned on three occasions, plus on an additional occasion to increase participation rates (four mailings overall). Student learning gain data, by teacher, are available if the particular student was with the same language arts and math teachers for two consecutive years. The data collected, including gender, race/ethnicity, education, teaching experience, grade level taught, subject area taught, technology training, average number of students in a class, number of computers available for student use, student access to computers, and years of experience in integrating computers into the curriculum are examined below.

Of the 136 surveys received overall in the study, 115 did not contain student learning gains data; therefore, the researcher could not use the data related to these individuals for investigating the research questions per se. The demographic data were examined, however, to determine if there was evidence of disproportional representation by gender and race/ethnicity between the 21 participants in this research, the remaining 115 incomplete data sets, and the 
District-level teacher representation by gender and race/ethnicity. These data are presented in Appendix A.

\section{Gender}

Nine and a half $\%(n=2)$ of the sample was male, and $90.5 \%(n=19)$ was female. This compares to $38.3 \%(n=44)$ male and $61.7 \%(n=71)$ female for the 115 incomplete data sets also collected in this study and the District's overall composition of $38.1 \%(n=2744)$ male and $61.9 \%(n=4452)$ female. Thus, the final research sample $(n=21)$ was more heavily represented proportionally by females as compared to the 115 incomplete data sets and the overall District data (Florida Department of Education Staff Information Database, 2010).

\section{Race/Ethnicity}

Analysis of the race/ethnic composition of the respondents indicated that 14.3\% $(n=3)$ were African American; $57.1 \%(n=12)$ Hispanic; $23.8 \%(n=5)$ White Non-Hispanic; and, 4.8\% $(n=1)$ Asian or Other. In comparison, of the 115 incomplete data sets representing those who responded also to the survey but did not have corresponding student learning gains data, $18.2 \%(n=21)$ were African American; 45.2\% $(n=52)$ Hispanic; 33.9\% $(n=39)$ White Non-Hispanic; and, 2.6\% $(n=3)$ Asian or Other. The District's overall race/ethnic composition for its teachers is as follows: $25.3 \%$ African American, 39.5\% Hispanic, 33.0\% White-Non Hispanic, and 2.2\% Asian or Other. Thus, this research sample was represented proportionally by Hispanic teachers more and less by African American teachers as compared to the incomplete data set individuals and the 
overall District teacher population (Florida Department of Education Staff Information Database, 2010).

Although race/ethnic representation at each school varied, the majority of teachers were in the Hispanic and White Non-Hispanic categories, which is consistent with the District's published numbers (Florida Department of Education Staff Information Database, 2010). The following represents teacher respondent race/ethnicity per school. First, American Senior High School was represented as follows: African American $(n=0)$, Hispanic $(n=1)$, and White Non-Hispanic $(n=0)$ and Asian/Pacific Islander $(n=0)$. Second, Barbara Goleman Senior was represented as follows: African American $(n=0)$, Hispanic $(n=4)$, White Non-Hispanic $(n=0)$ and Asian/Pacific Islanders $(n=0)$. Third, Hialeah Senior was represented as follows: African American $(n=1)$, Hispanic ( $n$ $=6)$, White Non-Hispanic $(n=3)$, and Asian/Pacific Islander $(n=0)$. Fourth, Miami Carol City Senior was not represented in any category. Fifth, Miami Lakes Educational Center was represented as follows: African American $(n=0)$, Hispanic $(n=2)$, White Non-Hispanic $(n=0)$ and Asian/Pacific Islanders $(n=0)$.

Finally, William H. Turner Technical Arts High was represented as follows:

African American $(n=2)$, Hispanic $(n=2)$, White Non-Hispanic $(n=0)$, and Asian/Pacific Islander $(n=0)$.

\section{Highest Degree Earned}

Analysis of the highest degrees earned by the respondents indicated that $38.1 \%(n=8)$ of the teachers earned a BA, BS, or a Vocational Certificate; $38.1 \%(n=8)$ of the teachers earned a Master's degree; $9.5 \%(n=2)$ of the 
teachers earned a Specialist degree (Ed.S.), which is 36 credit hours beyond a Master's degree; and $14.3 \%(n=3)$ of the teachers earned a Doctorate.

\section{Total Computer Integration Experience}

The number of years of computer integration experience reported by the respondents was as follows: $4.76 \%(n=1)$ of the teachers had taught using computers for one to two years; $52.4 \%(n=11)$ of the teachers had taught using computers for three to five years; $14.3 \%(n=3)$ of the teachers had taught using computers for six to ten years; and, $28.6 \%(n=6)$ of the teachers had taught using computers for more than ten years.

\section{Grade Levels Taught}

The grade level teachers taught were reported as follows: None of the teachers taught Grade nine only $(n=0) ; 9.5 \%(n=2)$ of the teachers taught Grade $10 ; 9.5 \%(n=2)$ of the teachers taught Grade 11; none of the teachers taught Grade 12 only $(n=0) ; 33.3 \%(n=7)$ of the teachers taught two different grades; and, $47.6 \%(n=10)$ of the teachers taught three or more grades.

\section{Subject/Vocational Areas Taught}

The subject areas teachers taught were reported as follows: $52.3 \%(n=$ 11) taught Reading/Language Arts classes; $28.6 \%(n=6)$ taught Special Education classes; $14.3 \%(n=3)$ taught English for Learners of a Second Language classes; and 4.8\% $(n=1)$ taught Career and Technical Education classes. 


\section{Years of Experience in Integrating Computers into the Curriculum}

Teachers reported on their years of experience integrating computers into the curriculum as follows: $52.4 \%(n=11) 5$ years or fewer; $14.3 \%(n=3) 10$ years or fewer; $23.8 \%(n=5) 15$ years or fewer; and 9.5\% $(n=2)$ more than 16 years integrating computers into the curriculum.

\section{Technology Training}

Teachers reported having received adequate technology training as follows: $33.3 \%(n=7)$ strongly agreed; $47.6 \%(n=10)$ agreed; $4.8 \%(n=1)$ were neutral; 10\% $(n=2)$ disagreed; and 4.8\% $(n=1)$ strongly disagreed.

\section{Average Number of Students in a Class}

The average number of students in class was reported as follows: $9.5 \%(n$ = 2) 10 or fewer; $61.9 \%(n=13) 25$ or fewer; and $28.6 \%(n=6) 26$ or more.

\section{Number of Computers Available for Student Use}

The number of computers available for students in the class was reported as follows: $42.9 \%(n=9)$ two or fewer; $33.3 \%$ five or fewer; $9.5 \%(n=2) 10$ or fewer; $14.3 \%(n=3) 15$ or fewer; and 4.8\% $(n=1)$ more than 15 .

\section{Student Access to Computer Labs}

Ninety and one half \% $(n=19)$ of the teachers reported that their students had access to a computer lab; $9.5 \%(n=2)$ reported not having access to a computer lab. Table 6 shows the frequencies and percentages of demographic characteristics in the sample. 
Table 6

Frequencies and Percentages of Demographic Characteristics of the Sample $(n=21)$

\begin{tabular}{|c|c|c|c|}
\hline Category & Variable & Frequency & Percentage \\
\hline \multirow[t]{2}{*}{ Gender } & Male & 2 & 10 \\
\hline & Female & 19 & 90 \\
\hline \multirow[t]{4}{*}{ Race/Ethnicity } & African American & 3 & 14 \\
\hline & White Non Hispanic & 5 & 24 \\
\hline & Asian/Pacific Islander & 1 & 5 \\
\hline & Hispanic & 12 & 57 \\
\hline \multirow[t]{4}{*}{ Highest Degree } & Bachelor of Arts & 8 & 38 \\
\hline & Master of Arts & 8 & 38 \\
\hline & Educational Specialist & 2 & 10 \\
\hline & Doctorate & 3 & 14 \\
\hline \multirow[t]{4}{*}{ Subject Areas } & English/Language Arts & 11 & 52 \\
\hline & Special Education & 6 & 29 \\
\hline & English for Learners & 3 & 14 \\
\hline & Career Technical Education & n 1 & 5 \\
\hline \multirow[t]{4}{*}{ Years of Experience } & Five or Fewer & 11 & 52 \\
\hline & Ten or Fewer & 3 & 14 \\
\hline & Fifteen or Fewer & 5 & 24 \\
\hline & Sixteen or More & 2 & 10 \\
\hline \multirow[t]{5}{*}{ Adequate Tech Training } & Strongly Agree & 7 & $33^{*}$ \\
\hline & Agree & 10 & 48 \\
\hline & Neutral & 1 & 5 \\
\hline & Disagree & 2 & 10 \\
\hline & Strongly Disagree & 1 & 5 \\
\hline
\end{tabular}

* Total Varies from $100 \%$ because of rounding. 


\section{Cross Tabulations of Background Demographic Variables}

Demographic variables of the study sample may be perceived as influential in determining the outcome. Cross tabulation of these demographic variables were run to identify any possible effect on the relationships of the independent variables to the dependent variable. Descriptive statistical procedures, such as chi-square distribution serve to aid researchers examining this effect and making a generalization of the findings to the wider population. A study of the population subset or sample can help the researcher achieve this (Hinkle, Wiersma, \& Jurs, 2003). Demographic and experiential variables such as gender, race/ethnicity, highest degree earned, and pedagogical experience are presented in Table 7.

Table 7

Cross Tabulations of Demographic Variables

\begin{tabular}{lccc} 
Variable & $x^{2}$ Value & $d f$ & $p$ \\
\hline Gembination & .69 & 3 & .88 \\
Gender and Degree & 6.49 & 4 & .17 \\
Gender and Race/Ethnicity & 1.08 & 3 & .78 \\
Race/Ethnicity and Degree & 6.27 & 9 & .71 \\
Race/Ethnicity and Experience & 8.10 & 12 & .78 \\
\hline
\end{tabular}

${ }^{*} p<.05$ (2-tailed)

The results of the chi-square analyses demonstrate that there were not statistically significant differences for the demographic combinations.

Consequently, teacher degree attainment and years of experience integrating 
technology in the classroom did not differ by gender. Further, degree attainment and years of experience integrating technology in the classroom did not differ by race/ethnicity category. Last, race/ethnic representation did not differ by gender.

Table 8 presents descriptive information and Cronbach's alphas for the four scales (comfort, attitude, confidence, and technical expertise) ranging from $.79-.88$, all acceptable by conventional internal consistency reliability standards (Cohen \& Cohen, 1983).

Table 8

Descriptive Statistics and Cronbach's Alpha Reliabilities for Research Variables $(N=21)$

\begin{tabular}{|c|c|c|c|c|c|}
\hline Variable & Minimum & Maximum & Mean & $S D$ & $\alpha$ \\
\hline $\begin{array}{l}\text { Student } \\
\text { Reading } \\
\text { Gains }\end{array}$ & .00 & .84 & .60 & .18 & \\
\hline $\begin{array}{l}\text { Comfort } \\
\text { Using } \\
\text { Computers }\end{array}$ & 10.00 & 40.00 & 31.67 & 6.89 & .86 \\
\hline $\begin{array}{l}\text { Attitude } \\
\text { Toward } \\
\text { Computers }\end{array}$ & 51.00 & 95.00 & 81.67 & 9.31 & .79 \\
\hline $\begin{array}{l}\text { Confidence } \\
\text { Using } \\
\text { Computers }\end{array}$ & 35.00 & 152.00 & 93.05 & 20.50 & .88 \\
\hline $\begin{array}{l}\text { Teacher } \\
\text { Technical } \\
\text { Expertise }\end{array}$ & 48.00 & 154.00 & 80.57 & 24.52 & .84 \\
\hline $\begin{array}{l}\text { Experience } \\
\text { Integrating } \\
\text { Curriculum }\end{array}$ & 1.00 & 5.00 & 3.48 & 1.33 & \\
\hline $\begin{array}{l}\text { Number of } \\
\text { Students in } \\
\text { Class }\end{array}$ & 5.00 & 26.00 & $\begin{array}{r}23.38 \\
\text { (con }\end{array}$ & $\begin{array}{l}5.48 \\
\text { nued) }\end{array}$ & \\
\hline
\end{tabular}




\begin{tabular}{lrrrrr}
\hline Variable & Minimum & Maximum & Mean & \multicolumn{1}{l}{$S D$} & $\alpha$ \\
\hline $\begin{array}{l}\text { Number of } \\
\text { Computers in }\end{array}$ & .00 & 15.00 & 4.95 & 5.21 & \\
Class & & & & & \\
$\begin{array}{l}\text { Pedagogical } \\
\text { Experience }\end{array}$ & .00 & 25.00 & 8.81 & 5.90 \\
\hline
\end{tabular}

\section{Testing the Research Hypotheses}

Zero-order correlation analysis was utilized first to examine the strengths and directions of relationships among the research variables. One-way ANOVAs were used to investigate possible group differences and a two-way ANOVA was used next to test for possible variable interactions. Linear regressions were subsequently employed in the first two hypotheses to test the degree to which the independent variables predicted the dependent variable (percent student learning gains). To test hypotheses three and four, a hierarchical regression was conducted to predict percent student learning gains after statistically controlling for teacher attitudes toward technology.

\section{Zero-Order Correlations Among Research Variables}

Zero-order correlations among the teacher technical literacy variables against the dependent variable percent student learning gains revealed positive correlations. Teacher comfort using computers was positively related to percent student learning gains $(r=.32, p<.07)$; attitude toward using computers was positively related to percent student learning gains $(r=.29, p<.10)$; teacher confidence level in using computers was positively related to percent student learning gains $(r=.33, p<.07)$; and finally, teacher technical expertise 
integrating technology and computers into the classroom was positively and statistically significantly related to percent student learning gains $(r=.43, p<$ .03). Experience was negatively related to percent student learning gains $(r=-$ $.01, p>.05$ ). Comfort using computers (measure of technical literacy), attitude towards using computers, and teacher confidence (measure of technical literacy) were each marginally related to percent student learning gains, but were statistically non-significant in the technical sense in that the $p$ values were greater than .05 (Cohen \& Cohen, 1983). Finally, because a statistically significant relationship was demonstrated between teacher technical expertise integrating technology and computers into the classroom (one of the three measures of technical literacy in this study) and percent student learning gains, the findings suggest that student learning gains were more likely to occur with those teachers with greater technical expertise integrating technology and computers into the classroom. Table 9 shows the correlations among the different study variables.

\section{Table 9}

Correlations Among Study Variables

\begin{tabular}{lllllll}
\hline Study & Student & Comfort & Attitude & Confidence & Teacher & Experience \\
Variables & Reading & Using & Toward & Using & Technical & Integrating \\
& Gains & & & & Expertise & Curriculum \\
\hline
\end{tabular}

Student

Reading

Gains

Comfort .33

Using

Computers

Attitude .29 $.76^{* *}$ Toward 


\begin{tabular}{llccccc}
\hline $\begin{array}{l}\text { Study } \\
\text { Variables }\end{array}$ & $\begin{array}{l}\text { Student } \\
\text { Reading } \\
\text { Gains }\end{array}$ & $\begin{array}{l}\text { Comfort } \\
\text { Using }\end{array}$ & $\begin{array}{c}\text { Attitude } \\
\text { Toward }\end{array}$ & $\begin{array}{l}\text { Confidence } \\
\text { Using }\end{array}$ & $\begin{array}{l}\text { Teacher } \\
\text { Technical } \\
\text { Expertise }\end{array}$ & $\begin{array}{l}\text { Experience } \\
\text { Integrating } \\
\text { Curriculum }\end{array}$ \\
\hline Computers & & & & & & \\
$\begin{array}{l}\text { Confidence } \\
\text { Using }\end{array}$ & .33 & .23 & .22 & - & & \\
Computers & & & & & & \\
$\begin{array}{l}\text { Teacher } \\
\text { Technical } \\
\text { Expertise }\end{array}$ & $.43^{*}$ & $.50^{*}$ & .11 & .21 & - & \\
$\begin{array}{l}\text { Experience } \\
\text { Integrating } \\
\text { Curriculum }\end{array}$ & -.01 & .28 & .36 & .12 & -.17 & \\
\hline
\end{tabular}

${ }^{*} p<0.05$ level (1-tailed); ${ }^{* *} p<0.01$ level (1-tailed)

\section{Further Analyses}

To clarify the possibility of teacher gender and teacher race/ethnic group differences by research variable, a series of one-way ANOVAs were conducted.

\section{For gender one-way ANOVAs:}

- percent learning gains $F(1,19)=.00, p=.49$

- $\quad$ comfort $F(1,19)=2.20, p=.08$

- attitude $F(1,19)=2.01, p=.09$

- confidence $F(1,19)=.74, p=.20$

- technical expertise integrating technology and computers into the classroom $\quad F(1,19)=.38, p=.28$

\section{For race/ethnicity:}

- percent learning gains $F(3,17)=.15, p=.46$

- comfort $F(3,17)=.37, p=.39$ 
- $\quad$ attitude $F(3,17)=.63, p=.35$

- $\quad$ confidence $F(3,17)=.50, p=.34$

- technical expertise integrating technology and computers into the classroom $F(3,17)=.30, p=.41$

To test for a possible teacher gender $\mathrm{X}$ race/ethnicity interaction with the dependent variable (percent student learning gains), a two-way ANOVA was conducted where it was found there was not a statistically significant interaction $F(1,15)=.47, p=.25$, partial $\eta^{2}=.03$.

What this all means in plain language is simply this: there is no statistical evidence in these analyses of either teacher gender or teacher race/ethnicity group differences by percent student learning gains, teacher comfort using computers, teacher attitude toward computers, teacher confidence using computers, and teacher technical expertise integrating technology and computers into the classroom. Further, there was no evidence of a teacher gender $\mathrm{X}$ race/ethnicity interaction with percent student learning gains as well.

Additional analyses were run also to check for possible systematic differences on the independent variables between the participants $(n=21)$ and those who had incomplete data sets (those who did not have student learning gains reported), and thus could not be used $(n=115)$. The $t$-test results indicated there were not statistically significant differences between the participant and incomplete data groups in the independent variables:

- comfort: $t(20)=-.34, p=.74$ (participants $M=31.67 ; S D=6.89$; incomplete group $M=31.01 ; S D=6.77$ ) 
- attitude: $t(20)=-1.46, p=.16$ (participants $M=81.67 ; S D=9.31$; incomplete group $M=82.73 ; S D=8.55$ )

- confidence: $t(20)=1.51, p=.15$ (participants $M=93.05 ; S D=20.50$; incomplete group $M=90.11 ; S D=18.96$ )

- technical expertise integrating technology and computers into the classroom: $t(20)=-.35, p=.73$ (participants $M=80.57 ; S D=24.52$; incomplete group $M=78.69 ; S D=28.05$ )

\section{Testing Hypothesis 1: Linear Regression Analysis}

Hypothesis 1 stated: There is not a positive relationship between the technical literacy of Career Academy instructors and the academic performance of Career Academy students.

Hypothesis 1 was tested using a linear regression analysis to determine the relationship of teacher technical expertise integrating technology and computers into the classroom to percent student learning gains. This variable was used as the only technical literacy variable predicting percent learning gains as it was the only one demonstrating a significant relationship with the dependent variable. The result indicated a moderately positive relationship $\left(R_{\text {adj }}^{2}=.14, p<\right.$ $.03 ; \beta=.43)$. What this means is that teacher technical expertise integrating computers and technology into the classroom accounts for $14 \%$ of the variance in student learning gains. For each standard deviation increase in teacher technical expertise integrating computers and technology into the classroom, this model predicts a .43 standard deviation increase in percent student learning gains. 


\section{Testing Hypothesis 2: Linear Regression Analysis}

Hypothesis 2 stated: There is not a positive relationship between the level of pedagogical experience of Career Academy instructors and the academic performance of Career Academy students. Pedagogical experience was determined using the variable years of experience in integrating computers into the curriculum. A linear regression analysis was used to examine the relationship of the variable years of experience in integrating computers into the curriculum to the dependent variable, percent student learning gains. The result indicated there was not a statistically significant relationship between the independent and dependent variables $\left(R_{\text {adj }}^{2}=.00, p<.48, \beta=-.01\right)$. Thus, teacher years of experience in integrating computers into the curriculum did not predict percent student learning gains.

\section{Testing Hypothesis 3: Hierarchical Regression}

Hypothesis 3 stated: After controlling for teacher attitudes toward technology integration, there is not a positive relationship between teacher technical literacy and student performance. A hierarchical regression was used to examine the relationship of teacher technical expertise integrating computers and technology into the classroom to percent student learning gains, while controlling for teacher attitudes toward technology integration. Again, teacher technical expertise integrating computers and technology into the classroom was the sole technical literacy variable used to predict the dependent variable because it alone demonstrated a significant relationship with percent student learning gains. In step 1, teacher attitude was entered into the regression equation $\left(R_{\text {adj }}^{2}=.036\right.$, 
$p=.10, \beta=.25)$. For the second step, teacher technical expertise integrating computers and technology into the classroom was entered into the regression equation $\left(R_{\text {adj }}^{2}=.12, p=.035, \beta=.40\right)$. Overall, the model explained $15.6 \%$ of the variance in percent student learning gains. Teacher attitude toward technology integration did not significantly predict student learning gains, but teacher technical expertise integrating computers and technology into the classroom did. In this regression model, for each standard deviation increase in teacher technical expertise integrating computers and technology into the classroom, controlling for teacher attitudes toward technology integration, a .40 standard deviation increase in percent student learning gains was predicted.

\section{Testing Hypothesis 4: Hierarchical Regression}

Hypothesis 4 stated: After controlling for teacher attitudes toward technology integration, there is not a positive relationship between teacher pedagogical experience and student performance. A hierarchical regression was used to examine the relationship of the predictor variable years of experience in integrating computers into the curriculum and the dependent variable percent student learning gains, while controlling for teacher attitudes toward technology integration. In step 1, attitude was entered into the regression equation $\left(R^{2}\right.$ adj $=$ $.036, p=.10, \beta=.34)$. For the second step, years of experience in integrating

computers into the curriculum was entered into the regression equation $\left(R_{\text {adj }}^{2}=\right.$ $.00, p=.19, \beta=-.14)$. Overall, the model explained $3.6 \%$ of the variance in student learning gains, but it was not statistically significant. Thus, neither teacher attitude toward technology integration nor years of experience in 
integrating computers into the curriculum significantly predicted percent student learning gains.

\section{Summary}

As revealed by the ANOVA results, there were not statistically significant group differences in any of the research variables (percent student learning gains, teacher comfort using computers, teacher attitude toward computers, teacher confidence using computers, and teacher technical expertise) by teacher gender or teacher race/ethnicity. Results of this study however suggested a moderately strong positive relationship between teacher technical expertise integrating computers and technology into the classroom and percent student learning gains. Thus, greater student learning gains were associated with greater teacher technical expertise teacher technical expertise integrating computers and technology into the classroom, even after controlling for teacher attitude towards computers. Neither teacher attitude toward technology integration nor years of experience in integrating computers into the curriculum significantly predicted percent student learning gains in the regression models.

In Chapter 5, an analysis of the study results and their implications for research, practice, theory, and policy are discussed. Information about the limitations of the study and recommendations for future research are also presented. 


\section{CHAPTER V}

\section{DISCUSSION}

Chapter 5 presents a brief summary of the study and an overview of the problem and purpose statement, followed by a discussion of the results. These are presented in terms of the findings surrounding each of the research questions as they relate to the literature. Implications for theory, policy, practice, and research are given, followed by limitations of the study, final observations and conclusions, and recommendations for future research.

\section{Summary of the Study}

\section{Overview of the Problem}

The development over the past three decades of advanced computer technology and the proliferation of the World Wide Web as a communication tool in business, industry, and education have changed the way business and education are conducted (Partnership for $21^{\text {st }}$ Century Skills, 2003). The global economic emphasis has shifted from the traditional local manufacturing of durable goods, to providing services and support for electronic hardware, computer software, personal communication applications, multimedia file sharing, and information mining technology (U.S. Department of Commerce, 2002, 2004). Training workers to compete in this global market requires higher-order critical thinking skills and technological abilities to maintain the technological advantage over developing countries across the world (Friedman, 2007). The level of technical literacy of the workforce and the ability to use critical thinking and mathematics and science skills in problem-solving tasks determines how 
effective workers will be in maintaining the jobs that might otherwise be outsourced to other countries (National Governors Association, 2008).

The need to provide advanced and portable employability skills has redefined the goals, instructional practices, and policy in education (Grubb \& Lazerson, 2005). Defining and updating evolving skills is the best strategy for workers to remain competitive and retain employment (Thijssen, Van de Heijden, \& Rocco, 2008). The traditional role of career and technical education (CTE) in training a competitive force places CTE teachers at the vanguard of the effort (Stone, 2002; Vocational Information Center, 2010). The trend among adults seeking work-related courses is to receive instruction from industry providers and professional associations closely related to the participants' employer (NCES, 2008). The number of students seeking CTE as an alternative to a college degree is increasing dramatically. Students in the technical fields find it easier to obtain a high wage job than students graduating from a 4-year college (NCES, 2008). Considering this state of affairs, the use of technology in industry and the educational setting requires instructors more than ever to have the ability to use and model world-class technological skills (Daggett, 2004; International Information and Communication Technology Literacy Panel, 2004).

\section{Purpose Statement}

The purpose of this study was to examine the relationship between the level of technical literacy of instructors in career academies and student academic performance. It was also undertaken to explore the relationship 
between the pedagogical training of instructors and the academic performance of their students.

\section{Review of Methods}

A nonexperimental ex post facto quantitative design was used to examine the four research questions. Teacher participants were administered an expanded version of the Teachers' Attitudes Toward Computers Questionnaire (TAC; Christensen \& Knezek, 2009). The predictor variables were Teacher Comfort Using Computers, Attitudes Towards Computer Use, Teachers' Confidence Level, Teachers' Technological Literacy, and Pedagogical Experience. The dependent variable was Percent Student Learning Gains in Reading. The level of academic performance of career academy students was determined comparing scores from the 2010- 2011 and 2011-2012 Florida Comprehensive Assessment Test reading subtest.

After examining the demographic information, zero-order correlational analyses were used to investigate the strength and direction of relationships among the research variables. Linear and hierarchical regression statistical procedures were used to examine combined relationships of multiple independent variables with a single dependent variable. ANOVAs were subsequently run to test for group differences. Linear and hierarchical regressions were then used to determine the degree to which the independent variables might predict the dependent variable (student learning gains) to answer the research questions (Creswell, 2002). 


\section{Discussions of the Results and Relationship to Previous Literature}

The following sections discuss the results for the research questions as revealed using survey and archival data, and theory found in the literature. Results of the data collected suggested that there were no statistically significant relationships found between the dependent variable and all but one of the independent variables examined. Results for Hypothesis 1 are discussed, followed by results for Hypotheses 2, 3, and 4.

\section{Hypothesis One}

Hypothesis 1 stated: There is not a positive relationship between the technical literacy of career academy instructors and the academic performance of career academy students. Results from the correlational analysis showed that there was a marginally positive relationship established between three of the predictor variables and the dependent variable Percent Student Learning Gains: Comfort Using Computers $(r=.32, p<.07)$, Attitude Using Computers $(r=.29, p$ $<.07)$, and Teacher Confidence Level $(r=.33, p<.07)$, but the results were statistically non-significant because their $p$ values were greater than .05 (Cohen \& Cohen, 1983). The strength and direction of relations between confidence and comfort (two of the technical literacy variables) and attitudes and the dependent variable were as expected from prior research (e.g., Reio \& Sutton, 2006). However, there was not sufficient statistical power because of the modest sample size to detect a statistically significant relation between the predictors and percent learning gains. What this means is that teacher confidence and comfort, as forms of technical literacy, and teacher attitudes should not be overlooked by 
future researchers. Larger samples would help tease out these relations more clearly as has been the case with larger studies in prior research (e.g., Reio \& Sutton, 2006). The strongest positive and statistically significant relationship with Percent Student Learning Gains was Teacher Technical Expertise Integrating Computers and Technology into the Classroom $(r=.43, p<.03)$. The linear regression results further supported this interpretation $\left(R^{2}\right.$ adj $=.14, p<.03 ; \beta=$ .43); thus, demonstrating a moderately strong effect size (Cohen \& Cohen, 1983). This finding suggested that student learning gains were more likely to occur with those teachers with greater technical expertise integrating computers and technology in the classroom as suggested by the literature (Bauer \& Kenton, 2005; Bebell, Russell, \& O’Dwyer, 2004; Friedman, 2007; Grubb \& Lazerson, 2005; Means \& Olson, 1995).

\section{Hypothesis Two}

Hypothesis 2 stated: There is not a positive relationship between the level of pedagogical experience of career academy instructors and the academic performance of career academy students. Results from the correlational analysis showed that a statistically significant relationship was not revealed among the variable Years of Experience in Integrating Computers into the Curriculum and the dependent variable Percent Student Learning Gains $(r=-.01, p>.05)$. Hypothesis 2 was further tested using a linear regression analysis to examine the relationship of the variable Years of Experience in Integrating Computers into the Curriculum to the dependent variable Student Learning Gains. The result indicated there was not a significant positive relationship $\left(R^{2}{ }_{\text {adj }}=.00, p<.48, \beta=\right.$ 
-.01 ) suggesting that the number of years of experience in integrating computers into the curriculum were not linked to student learning gains in this study.

Teacher technology use in the form of integration of computers into the curriculum does not in and of itself guarantee that the instructional style of the teacher will change for the better (Bauer \& Kenton, 2005). In this study, teacher pedagogical experience integrating computers into the curriculum had no demonstrable link with student learning gains. It may be that pedagogical experience integrating computers into the curriculum was far different from actually using technology to improve teaching practices sufficiently to improve learner performance. This result supports the findings of Cuban, Kirkpatrick, and Peck (2001) where they examined teacher and student use of technology in the curriculum and how it influenced instructional practices. Their results showed little evidence of student-centered instruction using the technology, irrespective of the teacher's gender, ethnic background, and pedagogical experience. A continuation of teacher-centered activities was observed, including lectures, review of class work/homework, working on assignments, and occasional use of low-tech hardware (Cuban et al., 2001). Becker and Ravitz (1999) explored the degree to which teacher use of technology influences constructivist teaching practices and how teachers might recognize their use of technology as being important to their instructional style. They found that exemplary teachers assigned their students uses of computers beyond word processing to include graphic and communication programs outside the everyday classroom use (Becker \& Ravitz, 1999). Constructivist methodology emphasizes the use of 
technology for production of student projects and collaborative/interactive research, rather than simply as word processing and Internet search tools (Means \& Olson, 1995). Simply said, experience making technology available in the curriculum will not necessarily change teachers' curriculum design, instructional style, or their philosophy towards interaction with students, thereby limiting the possible association of pedagogical experience making technology available in the curriculum to student learning gains.

\section{Hypothesis Three}

Hypothesis three 3 stated: After controlling for teacher attitudes toward technology integration, there is not a positive relationship between teacher technical literacy and student academic performance. Results from the correlational analysis showed that there was a moderately positive correlation between Teacher Attitudes Toward Technology Integration and Percent Student Learning Gains $(r=.29, p<.10)$, but it was not statistically significant because the $p$ value exceeded .05 (Cohen \& Cohen, 1983). However, the hierarchical regression analysis revealed a statistically significant relationship $\left(R_{\text {adj }}^{2}=.16, p<\right.$ .04) between the predictor variable Teacher Technical Expertise Integrating Computers and Technology into the Classroom and Student Learning Gains, after controlling for Teacher Attitudes Towards Technology. Thus, teacher technical literacy in the form of expertise integrating computers and technology into the classroom was positively linked to student learning gains. In prior research, attitudes toward computer use have been shown to be significant predictors of learning-related behavior above and beyond perceptions, 
personality traits and cognitive ability (Christensen \& Knezek, 2009; Robbins \& Judge, 2013).

\section{Hypothesis Four}

Hypothesis 4 stated: After controlling for teacher attitudes toward technology integration, there is not a positive relationship between teacher pedagogical experience and student academic performance? Results from the correlational analysis showed that the relation between Years of Experience in Integrating Computers into the Curriculum and Percent Student Learning Gains revealed no statistically significant relationship between the variables. A hierarchical regression was used to examine further the relationship of the predictor variable Years of Experience in Integrating Computers into the Curriculum and Student Learning Gains while controlling for Teacher Attitudes Toward Technology Integration. No statistically significant relationship was revealed $\left(R_{\text {adj }}^{2}=.00, p>.05\right)$. Thus, neither teacher attitude toward technology integration nor years of experience in integrating computers into the curriculum significantly predicted student learning gains.

ANOVA findings. As revealed by the ANOVA results, there were not statistically significant group differences with regard to any of the research variables (student learning gains, teacher comfort using computers, teacher attitude toward computers, teacher confidence using computers, and teacher technical expertise) by teacher gender or teacher race/ethnicity. Differences from the actual sample used and the larger sample of participating teachers with incomplete data sets were not significant for gender, race/ethnicity, or years of 
experience, indicating that the final sample was representative of the total sample. Thus, the findings related to answering the research questions were not a function of teacher gender, race/ethnicity, or years of experience.

This is similar to the results of a mixed-method study of teachers in two high schools located in Northern California's Silicon Valley by Cuban et al. (2001), who found the lack of a link of these demographic variables to teachers' use of technology. Their study used surveys of teachers, students, and administrators, as well as classroom observations and school archival data. Although the school had exceptional availability of technology and connectivity resources, they found this did not lead to widespread use of the technology, nor integration into the curriculum, regardless of teacher gender, ethnical background, or teaching experience (Cuban et al., 2001). Rather, they suggested that the "Historical Legacy" of the traditional high school, including the six-period day, teacher centered instruction, departmentalized boundaries, and lack of common planning periods may have prevented teachers from sharing ideas and creating an interdisciplinary common core curriculum (Cuban et al., 2001).

Another explanation they attributed to the lack of teacher technology integration was what they called the "slow revolution", or the lag of time it takes for a new idea or technology to reach full implementation. This includes the amount of time it takes for individuals and institutions to learn how to use and manage these technologies effectively. The development of career academies is intrinsically involved in trying to resolve these types of issues proactively (Kemple \& Scott-Clayton, 2004), but it may be that this study is revealing a possible 
historical legacy and/or slow revolution effect, explaining the relatively modest performance of the technical literacy variables in predicting percent learning gains (i.e., teacher technical expertise integrating computers and technology into the classroom was the only statistically significant predictor of student learning gains).

\section{Implications for Theory}

Dewey's concept that learning with a purpose is at the center of a meaningful education (Dewey, 1916), and Vygotsky's similar view that cognitive growth in the zone of proximal development takes place best in a meaningful contextual setting (Vygotsky, 1930) support the need for teacher mentoring and role modeling in today's technologically complex educational environment. Because of the support of the literature examined in this study for Dewey and Vygotsky's notions that teacher technical expertise is a positive contributor to student academic performance, educational theorists may take a closer look at teacher technology use skills in the classroom, and how modeling these skills serves to promote the students' success in learning portable world-class skills.

The career academies model of school reform aims to do just that, with teachers taking on the roles of facilitators and mentors, much as in the apprenticeship model common to the beginning of the Industrial Revolution. The difference is in the level of science, technology, engineering, and math skills, along with communication and critical thinking skills required for a competitive global workforce today (National Governors Association, 2008). Teachers in the $21^{\text {st }}$ century educational setting need to own and model the portable skills of the 
successful players in an ever increasing technological society. No longer are we competing against ourselves, but against a growing, capable, and motivated workforce that is only a digital image away (Friedman, 2007).

\section{Implications for Research}

The purpose of this study was to examine the relationship between the level of technical literacy of instructors in career academies and student academic performance. It also sought to explore the relationship between the pedagogical training of instructors and the academic performance of their students. A positive association was found between the level of technical expertise of instructors and the academic success of their students. Further, a marginally positive relationship was established between three of the predictor variables that the literature examined found to be significant as well: Comfort Using Computers, Attitude Using Computers, and Teacher Confidence Level. Years of Experience in Integrating Computers into the Curriculum showed a slight negative correlation to the dependent variable Percent Student Learning Gains. These findings indicate the need for further research to explore the links between the variables, preferably with larger samples and more proportional representation by teacher gender and race/ethnicity. Testing the association among the variables in differing settings beyond the southern Florida region would also add to the knowledge about the teacher technical literacy and student learning gain relationship.

More research needs to be conducted to define the direction that educational leaders and teachers should follow to ensure that every teacher is 
highly qualified not only in academic skills, but also in maintaining a world-class set of $21^{\text {st }}$ century skills required to model the competencies students must learn to become effective players in a highly competitive global economy (Daggett, 2004; Friedman, 2007; International Information and Communication Technology Literacy Panel, 2004).

\section{Implications for Practice}

Recruiting the most qualified teachers has always been an important task for education. As the qualifications shift, so does the responsibility of identifying highly qualified instructors. Miami-Dade County Public Schools are presently converting 229 of its schools to an all-wireless internet service. More will be converted as funds are identified. Access will be available to all classrooms, media centers, cafeterias, even the courtyards (Miami Today, 2012). A

November 2012 bond issue of $\$ 1.2$ billion dollars was approved by Miami-Dade County voters to provide funds for technology and capital improvements aimed towards modernizing the schools. One-hundred million dollars of the money has already been earmarked for expanding the wireless network to every school and upgrading the technology infrastructure (Smiley, 2013). Many school systems in the nation are embracing the use of portable computer technology to go paperless, replacing bulky textbooks for students and giving Internet access to do research and communicate with their teachers and their peers around the world (Hu, 2011).

Upgrading to the most sophisticated instructional technology by itself of course does not guarantee that the technology will bring benefits for the 
performance of the students. In a mixed-methods study of teacher technology use, Bauer and Kenton (2005) found that the training of teachers was equally important to providing the latest hardware and software in the classroom. Interpersonal and technical skills have also been found to affect strongly the degree to which new workers assimilate the culture and workplace norms through collaboration with supervisors and coworkers (Reio \& Sutton, 2006). The present study found a significant positive relation between teacher technology use expertise and the academic success of their students. This suggests that teacher training and upgrading of skills through professional development activities needs to be placed front and center in any plan to expand technology in the schools.

The empirical data from this study indicates that teacher technical expertise is positively linked to the academic performance of their students in a career academy setting. Identifying teachers who have the appropriate level of technical expertise is important to guide professional development needs. Multiple measures have been identified as the most effective means for determining teacher skills in technology use (Bebell, Russell, \& O'Dwyer, 2004). In this study, the researcher intended to use the Inventory of Teacher Technology Skills survey (Florida Department of Education, 2006), a yearly technology use questionnaire deployed by the Florida Department of Education, to determine teacher technology use skills as a reference point to triangulate data collected by his own technology literacy survey. However, use of the ITTS was discontinued by the FDOE during the course of the study due to a lack of 
participation from the teachers throughout the state, precluding its use in the current research.

The empirical findings revealed by this study could indicate a need for a change in policy and practice regarding teachers' ability to use technology in the classroom. At a time when technology skills have become of crucial importance, it seems that less information is available about those skills in today's teachers. The limited success of technology-use surveys and the educational leadership's need to implement their use suggests a possible obstacle in the ability to preparing a competitive workforce. The emphasis seems to be far more on purely academic skills which, albeit important, may fail to provide students the $21^{\text {st }}$ century skills that industry requires of its workers. There is a great need to identify teachers who need professional development in learning how to use the increasing number of technological tools (including computers) available to prepare students to be competitive in today's global workforce (Daggett, 2004). Integrating technology into the curriculum remains the most difficult task for educators to tackle. Bauer and Kenton (2005) identified some important obstacles preventing integration of technology, including difficulties with equipment, students' differing levels of expertise, a lack of compatible hardware and software, insufficient Internet access and limited bandwidth, along with insufficient teacher training. Educational leaders are given to the task of ensuring that the proper tools and infrastructure exist to create the conditions necessary for teachers and students to develop world class technical skills. They must also address teacher technical skills. 
Community and industry leaders need to support educational institutions in the training of the workforce. Technical advisory committees are a useful means of keeping schools current with the technology necessary to remain competitive in a global economy. With industry experts providing updated input regarding the direction in which to set the course, instructional design and professional content are finely attuned to the needs of industry. Another benefit of using advisory committees is the networking capacity that is made available to promote programs and identify certification requirements, funding, industrystandard equipment, scholarships, apprenticeships, partnerships, and job opportunities (Hake, 2010; Stone, 2002).

The data in this study indicate students have greater learning gains when their teachers have greater technical literacy. Preparing the workforce begins with preparing teachers. Technical literacy is required of almost every level of workers in industry, from the engineer, to the auto mechanic and beyond. It seems then that outstanding technical literacy should also be a requirement for those who teach students.

\section{Implications for Policy}

Educational leaders need to take steps to identify teachers who can serve as positive role models in today's changing educational environment. New parameters have been drawn by industry regarding the skills needed for students to successfully enter a new globally competitive workforce. Those new parameters need to be applied to the teachers that will be preparing the workforce because they are the ones who will introduce and model the skills for 
their students. Academic skills have long been identified as a prerequisite for a teacher to take leadership of a classroom. No longer is it merely an option to require teachers to show proficiency in technological skills. Just like academic skills, teachers need to be assessed as to their level of expertise using the modern tools of technology that industry requires of their workers.

In Florida, surveys to assess teacher technology use have failed because of low teacher participation. At a time when libraries are going virtual, and books are becoming electronic downloads, teacher technology use should be scrutinized carefully. Identifying teachers' ability to use technology and computers in the classroom should be a top educational priority. Educational leaders need to establish protocols that will certify that every teacher possesses those skills that industry requires of their students when they enter the workforce. Professional development needs must be addressed to make Florida's teachers world class leaders in technology implementation.

Educational leaders need to prioritize technology use and support by providing their schools with the latest hardware, software, and interconnectivity (Bauer \& Kenton, 2005). Many school systems have already opted to use bookless classrooms and media centers. Wireless networks within the schools facilitate access for students and teachers without being tethered to a connection. This allows students to use portable devices, including their own cell phones and electronic tablets to use all of the resources without the need to carry heavy loads of paper-based texts. It also provides a link to the bountiful research material online, and a communication tool between teachers, students, and other 
schools to do collaborative learning (Hu, 2011). Teacher technology training might well be the missing link that ties it all together.

\section{Limitations of the Study}

As in any research, this study has limitations. First, a convenience sample was used. Convenience sampling involves available and willing participants who are not systematically selected. This is a form of non-probability sampling, and it does not guarantee that the participants are representative of the population. Results from this type of sampling may not be used to generalize results to the entire population (Creswell, 2002). The purpose of this study was to explore the relationship between teachers' technological literacy and the academic success of students. The ANOVA findings after examining the demographics of the sample when compared to the general population revealed no significant differences (See Appendix A). Six schools from the Miami Dade County Public Schools were targeted to obtain teacher technological literacy data and student academic performance data because they represented a diverse demographic sample of the overall school system. Yet, they were not randomly selected, which could introduce some sort of systematic bias into the study.

The second limitation was a less than optimal response rate (Dillman, 2007). Although there was an initial $26.0 \%$ response rate, the researcher was only able to use 21 participants because data concerning student learning gains were not available for the remaining 115 . Every effort was employed to increase response rates, including closely following Dillman's (2007) guidelines for optimizing response rates, making four instead of three mailings, contacting 
principals and academy leaders and asking them to remind teachers to participate, and personally calling and/or visiting teachers asking for their assistance in the study. Some teachers who were verbally contacted by the researcher lamented the lack of time and a plethora of online survey requests from the State, the District and from research institutions. Survey fatigue may be the best way to describe this condition (Dillman, 2007). In addition, some teachers also noted informally that answering surveys may be a "risky affair" given the present emphasis on teacher accountability by the FLDOE, despite the fact that anonymity and generic reporting of teacher results were ensured at all times. Thus, because of the relatively low response rate, any generalizations from these findings should be made only cautiously at best.

Poor teacher response to surveys seems to be an endemic issue in Florida. Archival data from the 2010 ITTS were not available because of very low response rates. In many cases, the response rate to the researcher's survey was far better than the response rate to the FLDOE survey. Some of this may be attributed to teacher concerns that answering the State surveys may affect their jobs. The researcher could not use ITTS results in the study because it did not offer updated data.

Archival data for student performance were also difficult to obtain, due to the fact that the M-DCPS District did not report student data to the school principals for the 2011-2012 school year as has been the common practice since FCAT assessments have been in place. According to a District Administrative Director for Data and Assessment, the learning gains reports for the schools 
were not run due to the new "value added" formula for accountability used by the Florida Department of Education. The Director agreed to run the data specifically to cooperate with this study. Many of the 136 teachers who originally participated in the TAC survey had no data for student learning gains due to their particular teaching assignments and the composition of their student grade levels in that assignment.

The use of standardized test results as a measure of student academic success places an additional limitation on the data gathered. In traditionally structured career academy settings, the student cohort remains with the same teachers throughout their high school experience. The reality in large urban schools is that the mobility rate of students and teachers is such that it is nearly impossible to maintain a stable cohort. This means that using learning gains data is greatly limited as happened in this study. Future studies may need to use a larger population to obtain data. As the FCAT is phased out over the next two years, End of Course assessments will be used instead. These will provide more specific data with which to gauge student academic success. Vocational Learning Points and vocational certification data may also provide good indicators of student academic success. Student portfolios, academic records, vocational completion points, graduation rates, and postsecondary success rates may offer more accurate data on student academic success than a single standardized test. Accessing the data for an outside researcher could be facilitated by partnering with school districts in conducting the studies. The benefits for teacher professional development and student academic growth 
need to be exposed and recognized by all stakeholders before these partnerships are possible. Once the value of teacher technical literacy proves to be important for student academic growth, educational leaders might be willing to cooperate in future studies used and identify these issues.

\section{Recommendations for Future Research}

More participants need to be recruited for a future study. The lack of participation by teachers is the most restricting factor at getting reliable and representative data. Teachers personally expressed a negative opinion towards responding to any online surveys. The most common opinion was related to providing information to an unknown source. A lack of time to answer a multitude of online requests for information was also a common source of complaint in answering surveys (Dillman, 2007). Many teachers expressed concerns about how answering surveys might affect their jobs, due to the increasing accountability measures being implemented by the FLDOE and local school districts. Perhaps the greatest obstacle to teacher response might remain the lack of awareness that teachers have about the importance of technology in their professional development plans. Greater emphasis must be placed on investigating the relationship of teacher technology use in the classroom and student academic success. Teachers need more evidence to understand how much their effectiveness in using technology has on the success of their students in obtaining $21^{\text {st }}$ century employability skills.

Teacher technology use data can be collected using a variety of readily available instruments. The TAC survey used in this study has been demonstrated 
and validated to be an effective tool in collecting information about teacher attitude and expertise in using ICT and computer based data (Christensen \& Knezek, 2009). The ITTS instrument used by the FLDOE in previous years was a well designed, well validated survey (Barron et al., 2008) based on the National Education Technology Standards (NETS) developed by the International Society for Technology in Education (ISTE, 2008), but its use was limited by a lack of teacher participation. The standards for teacher technology use have been in use for decades, stemming from the efforts of organizations such as the International Society for Technology in Education (ISTE). Since 1979, ISTE has become one of the most trusted international resources for teacher technology information and implementation, with over 100,000 active members. Most states in the United States and many other countries adhere to the NETS developed and updated by ISTE as a blueprint for technology use development (ISTE, 2013).

The importance of workforce readiness is an issue that affects the entire nation, and every developing country in the world. Teacher technological literacy is at the core of preparing future workers. Further studies could target rural counties in Florida, and other school systems in states using the NETS as standards for teacher technology use. Alleviating "survey fatigue" in future studies might be achieved by conducting surveys early in the beginning of the school year, ahead of the onslaught of surveys that will likely reach the teachers. Recruiting academy leaders and other school site educational leaders would be helpful to relay the importance of the survey and reassure the teachers that no harm will result from honest participation. 
The present model of research could be used in Latin American countries with increasing access to technology in the schools, such as Argentina, Brazil, Colombia, Chile, Costa Rica, Peru, and Mexico. Identifying teacher professional development needs could be beneficial for these countries' educational systems, and the empirical data collected would contribute to the field of teacher professional development.

\section{Conclusion}

The influence of a teacher leading a career academy-related classroom is an important factor in the success of the students, as revealed in the literature. Teacher technological expertise is one of the vital influences on student success in the $21^{\text {st }}$ century. Industry practices modeled on the highest standards serve as a benchmark for students to gauge their success in a future career. A lack of proper teacher technological skills required by industry for the career at the center of the academy would be equivalent to a lack of leadership in a business enterprise. Identifying teacher basic and advanced technological skills should be a priority in designing world-class curriculum and instruction in a career academy.

The first step in identifying highly qualified teachers is in designing and implementing assessments based on industry standards. After all, we require students to pass the end-of course and certification assessments to grant them certificates of competency in specific areas. Adequate professional development can only be recommended based on industry-standard assessments applied on a district-wide basis. One means of ensuring effective teacher technology 
assessment is to add technological skills to the state requirements for teacher certification.

Student academic achievement was positively related in this study to teacher skills in using technology. Regardless of the career or vocational area, students performed better when their teachers were better prepared. School districts need to identify which teachers are in need of technology training and skills upgrading for the benefit of the students they teach. Professional development should be contingent upon teachers' skills needs to be more effective as models of technology use.

In future studies end of course assessments and specific vocational technology assessments might be used to determine student academic and technical success. FCAT scores will soon be a thing of the past in determining student academic success. Accountability measures will be based on different assessment data. Career technical education has effectively used vocational completion points as a measure of student success towards meeting the minimum requirements for certification in vocational areas. Regardless of how student success is determined, the relationship that their teachers' ability to model industry's top technology standards will have to their success will continue to be of crucial importance. Academic and professional skills are part of most teacher certification programs. Measuring teacher technology skills needs to become a priority determining teacher effectiveness in the $21^{\text {st }}$ century classroom. 


\section{REFERENCES}

Anderson, J. Q., \& Rainie, L. (2010). The impact of the Internet on institutions in the future (Survey Report). Washington, DC: Pew Research Center. doi:http://pewinternet.org/ /media//Files/Reports/2010/PIP Future\%20of\% 20internet $\% 202010 \% 20-\% 20$ institutions $\% 20-\% 20$ final.pdf

Barron, A. E., Hohlfeld, T.N., \& Ritzhaupt, A.E. (2008). Student tool for technology literacy (ST2L) development and pilot test final evaluation report. Office of Technology Learning and Innovation, Florida Department of Education.

Barron, A. E., Kemker, K., \& Harmes, C. (2003). Large-scale research study on technology in K-12 schools: Technology integration as it relates to the national technology standards. Journal of Research on Technology in Education, 35, 489-507.

Bauer, J., \& Kenton, J. (2005). Toward technology integration in the schools: Why it isn't happening. Journal of Technology and Teacher Education, $13,519-546$.

Baumol, W. J., Nelson, R. R., \& Wolff, E. N. (1994). The convergence of productivity, its significance, and its varied connotations. In W. J. Baumol, R. R. Nelson \& E. N. Wolff (Eds.), Convergence of productivity: Crossnational studies and historical evidence (pp. 3-19). New York, NY: Oxford University Press.

Bausch, S., \& Han, L. (2006, June 21, 2006). U.S. broadband composition reaches 72 percent at home, a 15 point year-over-year increase, according to Nielsen/Netratings. Message posted to http://www.nielsenonline.com/pr/pr 060621.pdf

Bebell, D., Russell, M., \& O'Dwyer, L. (2004). Measuring teachers' technology uses: Why multiple-measures are more revealing. Boston, MA: Technology and Assessment Study Collaborative, Boston College.

Becker, H. J. (1994). How exemplary computer-using teachers differ from other teachers: Implications. Journal of Research on Computing in Education, $26,33$.

Becker, H. J., \& Ravitz, J. L. (1999). The influence of computer and internet use on teachers' pedagogical practices and perceptions. Journal of Research on Computing in Education, 31, 356-384. 
Berners-Lee, T., \& Fischetti, M. (1999). Weaving the web: The original design and ultimate destiny of the world-wide web by its inventor. San Francisco, CA: Harper-SanFrancisco.

Berners-Lee, T., \& Fischetti, M. (2000). Weaving the Web: The original design and ultimate destiny of the world-wide web by its inventor (1st pbk. ed.). New York, NY: HarperBusiness.

Berners-Lee, T. (2010). Long live the web: A call for continued open standards and neutrality. Scientific American.

doi:http://www.scientificamerican.com/article.cfm?id=long-live-the-web

Board of the Partnership for 21st Century Skills (2003). Learning for the 21st Century: A report and mile guide for 21st century skills. Tuscon, AZ: The Board of the Partnership for 21st Century Skills.

Bonk, C. J., \& Cunningham, D. J. (1998). Searching for learner-centered, constructivist, and sociocultural components of collaborative educational learning tools. In C. J. Bonk \& K. S. King (Eds.), Electronic collaborators: Learner-centered technologies for literacy, apprenticeship, and discourse (pp. 25-50). Mahwah, NJ: Erlbaum.

Bottoms, G., Presson, A., \& Johnson, M. (1992). Making high schools work. Atlanta, GA: Southern Regional Education Board.

Bottoms, G., \& Sharpe, D. (1996). Teaching for understanding through integration of academic and technical education. Atlanta, GA: Southern Regional Education Board.

Bray, J. B.; Green, K. A., \& Kay, K. (2010). Up to the challenge. Partnership for 21st Century Skills. doi:http://www.p21.org/documents/CTE Oct2010.pdf

Broadbandinfo.com. (2010) What is bandwidth and how does it affect broadband connections? Retrieved from http://www.broadbandinfo.com/cable/speedtest/what-is-bandwidth-and-how-does-it-affect-broadbandconnections.html

Carl D. Perkins Career and Technical Education Improvement Act of 2006, Accountability U.S.C. SEC.113 (2006).

CCSO, N. G. A. (2011). Common Core State Standards. Retrieved from http://www.corestandards.org/ 
Christensen, R. (2002). Effects of technology integration education on the attitudes of teachers and students. Journal of Research on Technology in Education, 34, 411-433.

doi:http://mytechtips.pbworks.com/f/Effects+of+Technology+Integration+E ducation+on+the+Attitudes+of+Teachers+and+Students+(1).pdf

Christensen, R. W., \& Knezek, G. A. (2009). Construct validity for the teachers' attitudes toward computers questionnaire. Journal of Computing in Teacher Education, 25, 143(13)-143-155. Retrieved from http://find.galegroup.com.ezproxy.fiu.edu/gtx/infomark.do?\&contentSet=IACDocuments\&type=retrieve\&tabID=T002\&prodld=AONE\&docld=A2020740 $\underline{33 \& \text { source }=\text { gale } \& \text { srcprod }=\text { AONE\&userGroupName }=\text { flstuniv\&version }=1.0}$

Christensen, R., \& Knezek, G. (1996). Constructing the teachers' attitudes toward computers (TAC) questionnaire. (Reports - Research; Speeches/Meeting Papers; Tests/Questionnaires. Retrieved from Educational Resources Information Center database.

Christensen, R. a. K., Gerald (2002). Instruments for assessing the impact of technology in education. Computers in the Schools, 18, 5-25.

Cohen, J., \& Cohen, P. (1983). Applied multiple regression/correlation analysis for the behavioral sciences [electronic resource] (2nd ed.). Hillsdale, $\mathrm{NJ}$ : L. Erlbaum Associates.

Creswell, J.W. (2002). Educational research: Planning, conducting, and evaluating quantitative and qualitative research. Columbus, $\mathrm{OH}$ : MerrillPrentice Hall.

Cuban, L., Kirkpatrick, H., \& Peck, C. (2001). High access and low use of technologies in high school classrooms: Explaining the apparent paradox. American Educational Research Journal, 38, 813-834.

Dagget, W. R. (2004). America's most successful high schools: Case studies and resources on best practices. 2004 Model Schools Conference Proceedings: Case Studies of Successful Programs. New York, NY: International Center for Leadership in Education, Rexford.

Dewey, J. (1916). Democracy and education: An introduction to the philosophy of education (April, 1948 ed.). New York, NY: McMillan.

Dillman, D. A. (2007). Mail and Internet surveys: The tailored design method (2, 2007 update with new internet, visual, a mix-mode guide ed.). Hoboken, NJ: Wiley. 
Dillman, D. A., \& Smyth, J. D. (2007). Design effects in the transition to webbased surveys. American Journal of Preventive Medicine, 32(5, Supplement 1), S90-S96.

Duncan, A. (2010). Using technology to transform schools-Remarks by Secretary Arne Duncan at the Association of American Publishers Annual Meeting. Retrieved from: http://www2.ed.gov/news/speeches/2010/03/03032010.html

Educational Testing Service. (2003). Succeeding in the 21st century: What higher education must do to address the gap in information and communication technology proficiencies. Princeton, NJ: Educational Testing Service.

Engardio, P. (2005). A new world economy. Business Week, August 22/29, 2005. doi:http://www.businessweek.com/magazine/content/05 34/b3948401.htm

Epstein, S. R. (1998). Craft guilds, apprenticeship, and technological change in pre-industrial Europe. The Journal of Economic History, 58, 684-713.

Federal Communications Commisssion. (2008). Section 504 programs and activities accessibility handbook. Washington DC: Federal Communications Commission Consumer \& Governmental Affairs Bureau.

Federal Communications Commission. (2011). FCC strategic plan for fiscal years 2009-2014. Retrieved from http://transition.fcc.gov/omd/strategicplan/

Feldman, J. (2010). The state of broadband. InformationWeek, (July 10, 2010) Retrieved from http://www.informationweek.com/story/showArticle.jhtml?articlelD=225702 $\underline{723}$

FLDOE, Office of Technology Learning and Innovation. (2011). Florida Technology Literacy Profile. Retrieved from http://www.fldoe.org/BII/Instruct Tech/downloads/FLTechLiteracyProfile.p $\underline{\mathrm{df}}$

Florida Department of Education. (2007). Office of assessment and school performance, assessment and accountability briefing book 2007. Tallahassee, FL: Florida Department of Education. Retrieved from http://fcat.fldoe.org/pdf/BriefingBook07web.pdf

Florida Department of Education. (2007), Alternative certification in Florida: Fourth annual progress report. Florida Center for Interactive Media, Florida State University, Tallahassee, Florida. 
Florida Department of Education. (2006). Inventory of teacher technology skills. Bureau of Educational Technology, Tallahassee, Florida.

Florida Department of Education. (2002). Florida alternative certification program. Retrieved from http://www.altcertflorida.org/index.htm

Florida Legislature. (2006). A++ Legislation Secondary School Reform, HB 7087 (2006). Retrieved from http://www.myfloridahouse.gov/FileStores/Web/Statutes/FS08/CH1003/Se ction 1003.493. HTM

Friedman, T. L. (2007). The world is flat: A brief history of the twenty-first century. (1st Picador Edition, Further Updated and Expanded ed.). New York, NY: Picador/Farrar, Straus and Giroux.

Grubb, W. N., \& Lazerson, M. (1974). American education and vocationalism: A documentary history, 1870-1970. Edited, with an introduction and notes. New York, NY: Teachers College Press, Columbia University.

Grubb, W. N., \& Lazerson, M. (2005). Vocationalism in higher education: The triumph of the education gospel. Journal of Higher Education, 76, 12-25. Retrieved from http://find.galegroup.com.ezproxy.fiu.edu/gtx/retrieve.do?contentSet=IACDocuments\&resultListType=RESULT LIST\&arySerld=Locale $\% 28 \mathrm{en} \% 2 \mathrm{C}$ \%2C\%29\%3AFQE\%3D\%28KE\%2CNone\%2C70\%29Vocationalism+in+Hi gher+Education\%3A+The+Triumph+of+the+Education+Gospel\%24\&sgHit CountType=None\&inPS=true\&sort=DateDescend\&searchType=BasicSear chForm\&tablD=T002\&prodld=AONE\&searchld=R2\&currentPosition=1\&us erGroupName=flstuniv\&docld=A128170308\&docType $=$ IAC

Hake, Kathryne (2010). Vocational information center. Phoenixville, PA: Center for Arts and Technology, Pickering Campus.

Hayward, G. C., \& Benson, C. C. (1993). Vocational-technical education: Major reforms and debates 1917-present. Information Analyses, 39. doi:http://eric.ed.gov/PDFS/ED369959.pdf

Hill, J. G. (2011). Education and certification qualifications of departmentalized public high school-level teachers of core subjects: Evidence from the 2007-08 schools and staffing survey (Statistical Analysis Report No. NCES 2011-317). National Center for Education Statistics, U.S. Department of Education. Washington, DC. doi:http://nces.ed.gov/pubsearch/pubsinfo.asp?pubid=2011317 
Hinkle, D. E. (1983). How large should the sample be? A question with no simple answer? or. ... Educational and Psychological Measurement, 43, 10511060.

Hinkle, D. E., Wiersma, W., \& Jurs, S. G. (2003). Applied statistics for the behavioral sciences (5th ed.). New York, NY: Houghton Mifflin.

Horrigan, J. (2009). Home broadband adoption 2009 No. 202-419-4500dit). Washington, D.C. 20036: pewinternet.org. (Broadband adoption) Retrieved from http://www.kmbvideojournal2.com/download/commentaries/09/HomeBroadband-Adoption-2009.pdf

Hu, W. (2011). Math that moves: Schools embrace the iPad. The New York Times, 4.

Hull, D. (2003). Redefining CTE: Seizing a unique opportunity to help the "Neglected majority" become world-class students, workers and citizens. Techniques (ACTE) 78 no5 My 2003, 78(5), p. 30-36.

International Society for Technology in Education (ISTE) (2008). Retrieved from http://www.iste.org/Content/NavigationMenu/NETS/ForTeachers/2008Stan dards/NETS T Standards Final.pdf

International Telecommunications Union (2005). Final Report of the World Telecommunication/ICT Indicators Meeting, Geneva, 10-11 February 2005. Available from http://www.itu.int/md/meetingdoc. asp?type=sitems\&lang=e\&parent=D02-ISAP2B.1.1-C-0053

Isensee, L. (2011, 11/06/2011). Complex new Florida teacher evaluations tied to student test scores. Message posted to http://hechingerreport.org/content/complex-new-florida-teacherevaluations-tied-to-student-test-scores $6802 /$

Jackson, R. M. (2004). Technologies supporting curriculum access for students with disabilities. Wakefield, MA: National Center on Accessing the General Curriculum. Retrieved from http://aim.cast.org/learn/historyarchive/backgroundpapers/technologies supporti $\underline{\mathrm{ng}}$

Katz , I. R., \& Smith Macklin, A. (2007). Information and communication technology (ICT) literacy: Integration and assessment in higher education. Journal of Systemics, Cybernetics and Informatics, 5, 50-55.

Kemple, J. J., \& Scott-Clayton, J. (2004). Career Academies: Impacts on labor market outcomes and educational attainments. (Evaluation MDRC, Manpower Demonstration Research Corporation). 
Krejcie R.V., \& Morgan, D.W. (1970). Experimental design: Procedures for the behavioral sciences. Educational and Psychological Measurement, 30, 607-610. Retrieved from http://opa.uprrp.edu/InvlnsDocs/KrejcieandMorgan.pdf

Lazonick, W. (1994). Social organization and technological leadership. In W. J. Baumol, R. R. Nelson \& E. N. Wolff (Eds.), Convergence of productivity: Cross national studies and historical evidence (pp. 164-165-193). New York, NY: Oxford University Press.

Leeuw, E. D., Hox, J. J., Dillman, D. A., \& European Association of Methodology (2008). International handbook of survey methodology. New York, NY: Lawrence Erlbaum Associates.

Leiner, B. M., Cerf, V. G., Clark, D. D., Kahn, R. E. Kleinrock, L., \& Lynch, D. C. (2009). A brief history of the internet. ACM SIGCOMM Computer Communication Review, 39(5), 22-22--31. doi:http://doi.acm.org/10.1145/1629607.1629613

Licklider, J. C. R. (1960). Man-computer symbiosis. IRE (IEEE) Transactions on Human Factors in Electronics, HFE-1 (March 1960), 4-5, 11. doi:http://memex.org/licklider.pdf

Licklider, J. C. R. (1963). Memorandum for members and affiliates of the intergalactic computer network Kurzweil Accelerating Intelligence. doi:http://www.kurzweilai.net/memorandum-for-members-and-affiliates-ofthe-intergalactic-computer-network

Ludwig, S., \& Turner, D. (2010). Were the 2008 olympic games China's golden parachute? Paper presented at the European Applied Business Research (EABR) Conference Proceedings and the European College Teaching (ETLC) \& Learning Conference Proceedings, Dublin, Ireland. 369-370377. Retrieved from http://www.cluteinstitute.com/proceedings/2010 Dublin EABR Articles/Art icle\%20406.pdf

McNamara, Kerry S. (2003). ICTs, poverty and development: learning from experience. A background paper for the InfoDev Annual Symposium, Geneva, 9-10

December 2003. Washington, DC: World Bank. Available from http://www.infodev.org/files/1041 file Learning From Experience.PDF

Miami-Dade County School Board (2008). Miami-Dade County Public Schools Secondary School Reform Five Year Plan. Retrieved from http://ssr.dadeschools.net/flip/CEO.asp 
Milton, S., Flood, P., \& Dukes, M. (2006). Alternative certification in Florida: Fourth annual progress report. Tallahassee, Florida: The Florida State University Florida Center for Interactive Media.

National Education Association. (1960). Small-sample techniques. The NEA Research Bulletin, 38, 99.

National Governors Association. (2008). Benchmarking for success: Ensuring U.S. students receive a world-class education. Washington, DC: Council of Chief State School Officers, and Achieve, Inc. Retrieved from http://www.achieve.org/files/BenchmarkingforSuccess.pdf

Nelson, Richard R., \& Wright, Gavin (1994). The erosion of U.S. technological leadership as a factor in postwar economic convergence. W. J. Baumol, R. R. Nelson \& E. N. and Wolff (Eds.). Convergence of productivity: Cross-national studies and historical evidence (pp. 129-130-163). New York, NY: Oxford University Press, Inc.

No Child Left Behind Act of 2001, Statute U.S.C. 1 (2002). doi: http://www2.ed.gov/policy/elsec/leg/esea02/107-110.pdf

Office of Technology Learning and Innovation. (2008). Florida Innovates School Survey Results 2007-2008 Overview (annual). Online: Florida Department of Education. (FLDOE Technology Survey 2007-2008) doi: http://www.flinnovates.org/docs/FLInnovatesReport200708.pdf

Parshall, C. G., Harmes, J. C., Rendina-Gobioff, G., \& Jones, P. (2004). Final evaluation report: Teacher technology literacy inventory development and field test. Retrieved from http://www.flinnovates.org/docs/TeachTechLitFinalEval.pdf

Partnership for 21st Century Skills (2003). Learning for the $21^{\text {st }}$ Century: A report and mile guide for $21^{\text {st }}$ century skills. Washington, DC: Author.

Penuel, W. R., \& Wertsch, J. V. (1995). Vygotsky and identity formation: A sociocultural approach. Educational Psychologist, 30, 83-83-92.

Planty, M., Hussar, W., Snyder, T., Provasnik, S., Kena, G., Dinkes, R., KewalRamani, A., \& Kemp, J. (2008). The Condition of Education 2008 (NCES 2008-031). National Center for Education Statistics, Institute of Education Sciences, U.S. Department of Education. Washington, DC. Retrieved from http://nces.ed.gov/pubs2008/2008031.pdf 
Primo, Natasha (2003). Gender issues in the information society. Paris: United Nations Educational, Scientific and Cultural Organization (UNESCO). Available from http://portal.unesco.org/ci/en/file download.php/250561f24133814c18284f eedc30bb5egender issues.pdf

Prosser, C. A. (1913). The meaning of industrial education. In C. A. Bennett, \& W. T. Bawden (Eds.), Vocational education, Volume II (pp. 409-407-418). Peoria, Illinois: The Manual Arts Press. Retrieved from Google eBooks.

Pucel, D. J., \& Sundre, S. K. (1999). Tech prep articulation: Is it working? Journal of Industrial Teacher Education, 37, 26-37.

Ramilo, C. G. \& Pi Villanueva (2001, December). Issues, policies and outcomes: are ICT policies addressing gender equality? Paper presented at the United Nations ESCAP Expert Group Meeting to Review ICT Policy from a Gender Perspective, Bangkok, Thailand. Available from http://www.unescap.org/esid/GAD/Events/EGMICT2001/backgroundpaper .pdf

Raywid, M. A. (1996). Taking stock: The movement to create mini-schools, schools-within-schools, and separate small schools. New York, N Y: Institute for Urban and Minority Education. doi: http://dcbsimpson.com/Raywid\%201996\%20-\%20small\%20schools.pdf

Reio, T. G. \& Sutton, F. C. (2006). Employer assessment of work-related competencies and workplace adaptation. Human Resource Development Quarterly, 17, 305-324.

Rhodes, D. (2003, October). Two worlds-one Child: Shifting the question: How technical literacy and assessment improve student performance and education and career advancement. Paper presented at the meeting of the SREB High Schools That Work October 10, 2003 board meeting, Atlanta, GA: Southern Regional Education Board.

Rintels, J. (2008). An action plan for America: Using technology and innovation to address our nation's critical challenges. (Benton Foundation Initiatives). Washington, DC: Benton Foundation. Retrieved from http://www.benton.org/initiatives/broadband benefits/action plan

Rojewski, J. W. (2002). Preparing the workforce of tomorrow: A conceptual framework for career and technical education. Retrieved from http://www.akademik.unsri.ac.id/download/journal/files/scholar/v27n1.pdf\#page= $\underline{10}$

Rossett, A. (2002). The ASTD e-Learning Handbook. New York, NY: McGrawHill. 
Secretary's Commission on Achieving Necessary Skills (June, 1991). What work requires of schools: A SCANS report for America 2000. Washington, DC: U.S. Department of Labor.

School Board of Miami- Dade County (2009). Office of School Improvement (Ed.). A resource guide for effective EESAC implementation. Miami, FL: Miami-Dade County Public Schools. doi: http://osi.dadeschools.net/pdf/Resource Guide.pdf

Shermis, M. D., \& Long, S. K. (2009). Multitrait-multimethod analysis of FCAT reading and writing: Or is it writing and reading? Journal of Psychoeducational Assessment, 27(4), 296-311.

Smiley, D. (2013). Miami-Dade schools bond issue timeline: wireless and playgrounds first. The Miami Herald. Retrieved from http://www.miamiherald.com/2013/01/17/3187979/miami-dade-schoolsbond-issue.html

Snedden, D. (1910). The problem of vocational education (The Riverside Press, ed.). Cambridge, MA: Houghton Mifflin Company. doi: http://books.google.com/ebooks/reader?id=YLyfAAAAMAAJ\&printsec=fro ntcover\&output=reader\&source=webstore bookcard

State Board of Education, Florida. (2007). Assessment and accountability briefing book. Retrieved from http://fcat.fldoe.org/pdf/BriefingBook07web.pdf

The Board of Trustees of the Leland Stanford Junior University. (2011). Stanford's key to information literacy. Retrieved from http://skil.stanford.edu/intro/research.html

Stone, J. R. (2002, December). What do we know about career and technical education: Preliminary findings from 2000 \& 2001 NRCCTE projects. Briefing paper presented at the 2002 Annual Conference of the Association for Career and Technical Education, National Research Center for Career and Technical Education, Las Vegas, NA. (ERIC Document Reproduction Service No. ED 473647)

Sunshine State Standards FS 1003.41 (2009). Retrieved from http://www.myfloridahouse.gov/FileStores/Web/Statutes/FS09/CH1003/Se ction 1003.41.HTM

The Board of Trustees of the Leland Stanford Junior University. (2011). Stanford's key to information literacy. Retrieved from http://skil.stanford.edu/intro/research.html 
Thijssen, J. Van der Heijden, B., \& Rocco, T. (2008). Toward the EmployabilityLink model: Current employment transition to future employment perspectives. Human Resource Development Review, 7, 165-183.

Retrieved from http://www.worldcat.org/title/toward-the-employability-linkmodel-current-employment-transition-to-future-employmentperspectives/oclc/432031331

U.S. Department of Commerce. (2002). A Nation Online: How Americans are expanding their use of the Internet. (U.S. Census Bureau Report) Washington DC: U.S. Department of Commerce. Retrieved from http://www.ntia.doc.gov/ntiahome/dn/html/anationonline2.htm

U. S. Department of Commerce (2004). A Nation Online: Entering the broadband age (Government Report No. 6). Washington DC: U.S. DEPARTMENT OF COMMERCE, National Telecommunications and Information Administration.

U.S. Department of Education Office of Planning, Evaluation and Policy Development, Policy and Program Studies Service (2008). Implementation study of smaller learning communities final report. Retrieved from http://www.ed.gov/about/offices/list/opepd/ppss/reports.html.

United States Commission on Aid to Vocational Education (1914). Vocational education: Report of the commission on national aid to vocational education (Congressional Report, Public Resolution No. 16). Washington, DC: Sixty-third Congress (S.J. res. 5). Retrieved from http://books.google.com/ebooks?op=add\&sig=ACfU3U30oXa8O6yacaueil AKnEhUk2aTAw\&uid=105352962741489434430\&as coll=7\&id=hoFNAA AAYAAJ

United States of America, 107th Congress 2002.

United States Department of Labor (2001). Virtual learning in DOL: Universal accessibility through your web browser. Washington, DC: U.S. Dept. of Labor.

United States National Commission on Excellence in Education (1983). A Nation at Risk: The Imperative for Educational Reform, a report to the nation and the Secretary of Education. Washington, DC: United States Department of Education.

United States Office of Educational Technology (2000). E-learning. Washington, DC: U.S. Dept. of Education, Office of Educational Technology. 
U.S. Congress, Office of Technology Assessment, Power On! New Tools for Teaching and Learning, OTA-SET-379 (Washington, DC: U.S. Government Printing Office, September 1988).

Van Atta, R. (2011). Fifty years of innovation and discovery. Retrieved from http://www.darpa.mil/About/History/First 50 Years.aspx

Vygotsky, L. S. (1986). Kozulin A. (Ed.), Thought and language. (A. Kozulin Trans.). Cambridge, MA: The MIT Press.

Vygotsky, L. S. (1978). Mind in society: The development of higher psychological processes. Cambridge, MA: Harvard University Press.

Website Optimization Services (October, 2006). China to Pass US in Total Broadband Lines - UK Broadband to Double by 2008 - US Broadband Penetration Jumps to $76.3 \%$ Among Active Internet Users. Retrieved from http://www.websiteoptimization.com/bw/0610/

WebSiteOptimization.com. (2010). US drops to 22nd in broadband speed worldwide - fastest broadband cities: College towns - US broadband penetration drops to $95.2 \%$ among active internet users - April 2010 bandwidth report. Retrieved from http://www.websiteoptimization.com/bw/1004/

Wertsch, J. V. (1985). Vygotsky and the social formation of mind. Cambridge, MA: Harvard University Press.

Wehmeyer, M. L., Smith, S. J., Palmer S. B., \& Davies, D. K. (2004) Technology use by students with disabilities: An overview. Journal of Special Education Technology, 19, 7-22.

Wirth, A.G. (1992). Education and work for the year 2000: Choices we face. San Francisco, CA: Jossey-Bass.

Wonacott, M. E. (2001). Implications of distance education for CTE. ERIC digest no. 227. Columbus, OH: ERIC Clearinghouse on Adult, Career, and Vocational Education.

Wonacott, M. E. (2001). Keeping vocational/career-technical educators current. (ED449377). Trends and Issues Alert no. 23. Retrieved from http://www.eric.ed.gov/PDFS/ED449377.pdf

Wonacott, M. E. (2003). History and evolution of vocational and career-technical education. A compilation (Compilation No. ED 482 359). Columbus, $\mathrm{OH}$ : Center on Education and Training for Employment. Retrieved from doi:http://www.eric.ed.gov/PDFS/ED482359.pdf 
Wyatt, E. (2010, June 27, 2010). Broadband availability to expand. The New York Times, Retrieved from http://www.nytimes.com/2010/06/28/technology/28broadband.html?pagew anted $=1 \& r=1 \&$ th\&emc $=$ th

Zins, J. E. (2004). Building academic success on social and emotional learning: What does the research say? New York, NY: Teachers College Press.

Zirkle, C. J., Martin, L., \& McCaslin, N. L. (2007). Study of State Certification/Licensure Requirements for Secondary Career and Technical Education Teachers. St. Paul, Minnesota 55108-6197: National Research Center for Career and Technical Education. doi: http://136.165.122.102/UserFiles/File/pubs/State Certification secondary teachers.pdf 


\begin{tabular}{|c|c|c|c|}
\hline \multicolumn{4}{|c|}{$\begin{array}{c}\text { APPENDIX A } \\
\text { TECHNOLOGY USES AND ATTITUDES SURVEY }\end{array}$} \\
\hline$\#$ & Section & Question & Response \\
\hline 1 & ABOUT YOU & Name of your school: (Choose one) & 6 choices \\
\hline 2 & ABOUT YOU & What is your gender? & 2 choices \\
\hline 3 & ABOUT YOU & What is your race or ethnicity? (Choose one) & 5 choices \\
\hline 4 & ABOUT YOU & Highest degree you have earned: & 8 choices \\
\hline 5_1 & ABOUT YOU & $\begin{array}{l}\text { What is the main academic or career technical area } \\
\text { you are certified in? }\end{array}$ & 11 choices \\
\hline 5_2 & ABOUT YOU & $\begin{array}{l}\text { What is the main academic or career technical area } \\
\text { you are certified in? }\end{array}$ & 11 choices \\
\hline 5_3 & ABOUT YOU & $\begin{array}{l}\text { What is the main academic or career technical area } \\
\text { you are certified in? }\end{array}$ & 11 choices \\
\hline $6 \_1$ & ABOUT YOU & What grade level(s) do you currently teach? & 4 choices \\
\hline $6-2$ & ABOUT YOU & What grade level(s) do you currently teach? & 4 choices \\
\hline $6 \_3$ & ABOUT YOU & What grade level(s) do you currently teach? & 4 choices \\
\hline 7 & ABOUT YOU & $\begin{array}{l}\text { What is the Average number of students in your } \\
\text { classroom for instruction? }\end{array}$ & 7 choices \\
\hline 8 & ABOUT YOU & $\begin{array}{l}\text { How many computers do you have in your classroom } \\
\text { for instruction }\end{array}$ & 6 choices \\
\hline 9 & ABOUT YOU & $\begin{array}{l}\text { How many years have you been using computers for } \\
\text { instruction? }\end{array}$ & 5 choices \\
\hline 10 & ABOUT YOU & Do you have access to a computer lab? & 2 choices \\
\hline \multirow[t]{2}{*}{11} & ABOUT YOU & $\begin{array}{l}\text { If yes, how many hours each week do your students } \\
\text { use the lab? }\end{array}$ & 6 choices \\
\hline & & $\begin{array}{l}\text { Please rate the following questions using the } \\
\text { scale below: } \\
\text { 1= Strongly Disagree } \\
2=\text { Disagree } \\
3=\text { Neutral } \\
4=\text { Agree } \\
5=\text { Strongly Agree }\end{array}$ & \\
\hline 12 & $\begin{array}{l}\text { Confidence and } \\
\text { Comfort Using } \\
\text { computers (CCUC) }\end{array}$ & I have had adequate training in using computers. & Likert 1-5 \\
\hline 13 & CCUC & I use computers effectively in my classroom. & Likert 1-5 \\
\hline 14 & CCUC & $\begin{array}{l}\text { I am comfortable giving computer assignments to my } \\
\text { students. }\end{array}$ & Likert 1-5 \\
\hline 15 & CCUC & The computer enhances my teaching. & Likert 1-5 \\
\hline 16 & CCUC & $\begin{array}{l}\text { I am comfortable using computers during classroom } \\
\text { instruction. }\end{array}$ & Likert 1-5 \\
\hline 17 & CCUC & $\begin{array}{l}\text { My use of computer technology enhances student } \\
\text { performance. }\end{array}$ & Likert 1-5 \\
\hline 18 & CCUC & $\begin{array}{l}\text { My incorporation of multi-media into lessons } \\
\text { enhances my teaching. }\end{array}$ & Likert 1-5 \\
\hline 19 & CCUC & I am comfortable with computer terminology. & Likert 1-5 \\
\hline
\end{tabular}




\begin{tabular}{|c|c|c|c|}
\hline 20 & $\begin{array}{l}\text { Attitudes Towards } \\
\text { Computer Use } \\
\text { (ATCU) }\end{array}$ & $\begin{array}{l}\text { I would like every student in my classes to have } \\
\text { access to a computer }\end{array}$ & Likert 1-5 \\
\hline 21 & (ATCU) & Computer skills are essential to my students & Likert 1-5 \\
\hline 22 & (ATCU) & $\begin{array}{l}\text { I feel tense when people start talking about } \\
\text { computers }\end{array}$ & Likert 5-1 \\
\hline 23 & (ATCU) & $\begin{array}{l}\text { I feel pressure from others to integrate the computer } \\
\text { into my classroom. }\end{array}$ & Likert 5-1 \\
\hline 24 & (ATCU) & $\begin{array}{l}\text { I would like my students to be able to use the } \\
\text { computer more. }\end{array}$ & Likert 1-5 \\
\hline 25 & (ATCU) & Computers are dehumanizing. & Likert 5-1 \\
\hline 26 & (ATCU) & I avoid the computer whenever possible. & \begin{tabular}{|l} 
Likert 5-1 \\
\end{tabular} \\
\hline 27 & (ATCU) & Computer instruction is just another fad. & Likert 5-1 \\
\hline 28 & (ATCU) & $\begin{array}{l}\text { The use of computers should be confined to } \\
\text { computer courses. }\end{array}$ & Likert 5-1 \\
\hline 29 & (ATCU) & I like using the computer to solve complex problems. & \begin{tabular}{|l} 
Likert 5-1 \\
\end{tabular} \\
\hline 30 & (ATCU) & $\begin{array}{l}\text { More training would increase my use of the computer } \\
\text { in the classroom. }\end{array}$ & Likert 5-1 \\
\hline 31 & (ATCU) & Computers diminish my role as a teacher. & \begin{tabular}{|l} 
Likert 5-1 \\
\end{tabular} \\
\hline 32 & (ATCU) & $\begin{array}{l}\text { Computers should be incorporated into the } \\
\text { classroom curriculum. }\end{array}$ & Likert 1-5 \\
\hline 33 & (ATCU) & Computers make my job easier. & Likert 1-5 \\
\hline 34 & (ATCU) & $\begin{array}{l}\text { Computers further the gap between students along } \\
\text { socio-economic lines. }\end{array}$ & Likert 5-1 \\
\hline 35 & (ATCU) & Computer skills will help me as a professional. & Likert 1-5 \\
\hline 36 & (ATCU) & $\begin{array}{l}\text { Learning computers makes high demands on my } \\
\text { professional time. }\end{array}$ & Likert 5-1 \\
\hline 37 & (ATCU) & Computers change my role as a teacher. & Likert 1-5 \\
\hline 38 & (ATCU) & I can help others solve computer problems. & Likert 1-5 \\
\hline 39 & (ATCU) & Computers enhance classroom instruction. & \begin{tabular}{|l} 
Likert 1-5 \\
\end{tabular} \\
\hline 40 & (ATCU) & $\begin{array}{l}\text { Wireless Internet connections would enhance } \\
\text { learning for my students. }\end{array}$ & Likert 1-5 \\
\hline 41 & $\begin{array}{l}\text { Teacher } \\
\text { Confidence Level }\end{array}$ & $\begin{array}{l}\text { Generate student grades using available software } \\
\text { programs. }\end{array}$ & Likert 1-5 \\
\hline 42 & $(\mathrm{TCL})$ & Create charts in a spreadsheet program. & Likert 1-5 \\
\hline 43 & $(\mathrm{TCL})$ & Create a presentation on a computer. & Likert 1-5 \\
\hline 44 & $(\mathrm{TCL})$ & Create a lesson or unit that incorporates technology. & \begin{tabular}{|l} 
Likert 1-5 \\
\end{tabular} \\
\hline 45 & $(\mathrm{TCL})$ & Create newsletters using word processing. & \begin{tabular}{|l} 
Likert 1-5 \\
\end{tabular} \\
\hline 46 & $(\mathrm{TCL})$ & Enter information in a database. & Likert 1-5 \\
\hline 47 & (TCL) & $\begin{array}{l}\text { Create a concept map using a graphic organizer } \\
\text { (e.g., Inspiration). }\end{array}$ & Likert 1-5 \\
\hline 48 & $(\mathrm{TCL})$ & Use a scanner to place an image in a document. & Likert 1-5 \\
\hline 49 & $(\mathrm{TCL})$ & Select a printer on a network. & \begin{tabular}{|l} 
Likert 1-5 \\
\end{tabular} \\
\hline 50 & $(\mathrm{TCL})$ & Take a picture using a digital camera. & \begin{tabular}{|l} 
Likert $1-5$ \\
\end{tabular} \\
\hline 51 & $(\mathrm{TCL})$ & $\begin{array}{l}\text { Connect a digital camera to the computer to } \\
\text { download the pictures. }\end{array}$ & Likert 1-5 \\
\hline 52 & $(\mathrm{TCL})$ & Edit and manipulate digital photos. & \begin{tabular}{|l} 
Likert 1-5 \\
\end{tabular} \\
\hline 53 & $(\mathrm{TCL})$ & Create a movie on the computer. & Likert 1-5 \\
\hline 54 & (TCL) & Access and retrieve information on the server. & Likert 1-5 \\
\hline
\end{tabular}




\begin{tabular}{|c|c|c|c|}
\hline 55 & (TCL) & Research and gather information from the Internet. & Likert 1-5 \\
\hline 56 & $(\mathrm{TCL})$ & Design and create a web page. & Likert 1-5 \\
\hline 57 & (TCL) & Back up files on my hard drive. & Likert 1-5 \\
\hline 58 & (TCL) & Send an email with an attachment. & Likert 1-5 \\
\hline 59 & (TCL) & Install software on the computer. & Likert 1-5 \\
\hline 60 & $(\mathrm{TCL})$ & Connect to the Internet wirelessly. & Likert 1-5 \\
\hline 61 & (TCL) & Recognize the unethical uses of technology. & Likert 1-5 \\
\hline 62 & $\begin{array}{l}\text { Integration of } \\
\text { Computers Into the } \\
\text { Classroom }\end{array}$ & $\begin{array}{l}\text { My students use word processing as a tool for } \\
\text { writing. }\end{array}$ & Likert 1-5 \\
\hline 63 & $(\mathrm{ICIC})$ & $\begin{array}{l}\text { I use word processing for lesson plans, newsletters, } \\
\text { and letters to parents. }\end{array}$ & Likert 1-5 \\
\hline 64 & $(\mathrm{ICIC})$ & $\begin{array}{l}\text { My students use spreadsheets to present } \\
\text { mathematical concepts. }\end{array}$ & Likert 1-5 \\
\hline 65 & $(\mathrm{ICIC})$ & $\begin{array}{l}\text { I use spreadsheets to create charts and graphs for } \\
\text { my students. }\end{array}$ & Likert 1-5 \\
\hline 66 & $(\mathrm{ICIC})$ & $\begin{array}{l}\text { My students use email or chats to gather information } \\
\text { from experts. }\end{array}$ & Likert 1-5 \\
\hline 67 & $(\mathrm{ICIC})$ & $\begin{array}{l}\text { I use the Internet to participate in discussion groups } \\
\text { for } \\
\text { professional development. }\end{array}$ & Likert 1-5 \\
\hline 68 & $(\mathrm{ICIC})$ & $\begin{array}{l}\text { My students create electronic books on the computer } \\
\text { using a variety of media, e.g., text, graphics, audio or } \\
\text { video. }\end{array}$ & Likert 1-5 \\
\hline 69 & $(\mathrm{ICIC})$ & $\begin{array}{l}\text { I use digital images to create picture books for } \\
\text { students. }\end{array}$ & Likert 1-5 \\
\hline 70 & $(\mathrm{ICIC})$ & $\begin{array}{l}\text { My students use a variety of media to create } \\
\text { electronic portfolios. }\end{array}$ & Likert 1-5 \\
\hline 71 & $(\mathrm{ICIC})$ & $\begin{array}{l}\text { I use the computer for classroom management, e.g. } \\
\text { seating charts, attendance, and assignments. }\end{array}$ & Likert 1-5 \\
\hline 72 & $(\mathrm{ICIC})$ & $\begin{array}{l}\text { My students create multimedia presentations using a } \\
\text { variety of media. }\end{array}$ & Likert 1-5 \\
\hline 73 & $(\mathrm{ICIC})$ & $\begin{array}{l}\text { I use the station to present student's work } \\
\text { presentation. }\end{array}$ & Likert 1-5 \\
\hline 74 & $(\mathrm{ICIC})$ & $\begin{array}{l}\text { My students use graphic organizers, e.g., } \\
\text { Inspiration, to develop concept maps. }\end{array}$ & Likert 1-5 \\
\hline 75 & $(\mathrm{ICIC})$ & $\begin{array}{l}\text { I use graphic organizers to present concepts to the } \\
\text { class. }\end{array}$ & Likert 1-5 \\
\hline 76 & $(\mathrm{ICIC})$ & $\begin{array}{l}\text { My students search for and evaluate information on } \\
\text { the Internet. }\end{array}$ & Likert 1-5 \\
\hline 77 & $(\mathrm{ICIC})$ & $\begin{array}{l}\text { I search for and evaluate information on the Internet } \\
\text { when I prepare my lessons. }\end{array}$ & Likert 1-5 \\
\hline 78 & $(\mathrm{ICIC})$ & $\begin{array}{l}\text { My students use authoring software to develop web } \\
\text { pages. }\end{array}$ & Likert 1-5 \\
\hline 79 & $(\mathrm{ICIC})$ & I create web pages for instruction. & Likert 1-5 \\
\hline 80 & $(\mathrm{ICIC})$ & $\begin{array}{l}\text { My students create desktop movies to communicate } \\
\text { thoughts, ideas, and stories. }\end{array}$ & Likert 1-5 \\
\hline 81 & $(\mathrm{ICIC})$ & $\begin{array}{l}\text { I use multimedia presentations to introduce learning } \\
\text { activities to students. }\end{array}$ & Likert 1-5 \\
\hline 82 & $(\mathrm{ICIC})$ & Small group discussion & Likert 1-5 \\
\hline
\end{tabular}




\begin{tabular}{|l|l|l|l|}
\hline 83 & $(\mathrm{ICIC})$ & Individual instruction & Likert 1-5 \\
\hline 84 & $(\mathrm{ICIC})$ & Cooperative groups & Likert 1-5 \\
\hline 85 & $(\mathrm{ICIC})$ & As a reward & Likert 1-5 \\
\hline 86 & $(\mathrm{ICIC})$ & Independent learning & Likert 1-5 \\
\hline 87 & $(\mathrm{ICIC})$ & to tutor & Likert 1-5 \\
\hline 88 & $(\mathrm{ICIC})$ & To promote student-centered learning & Likert 1-5 \\
\hline 89 & $(\mathrm{ICIC})$ & As a research tool for students & Likert 1-5 \\
\hline 90 & $(\mathrm{ICIC})$ & As a problem-solving/decision-making tool & Likert 1-5 \\
\hline 91 & $(\mathrm{ICIC})$ & $\begin{array}{l}\text { As a productivity tool (to create charts, reports or } \\
\text { other products) }\end{array}$ & Likert 1-5 \\
\hline 92 & $(\mathrm{ICIC})$ & As a classroom presentation tool & Likert 1-5 \\
\hline 93 & $(\mathrm{ICIC})$ & $\begin{array}{l}\text { As a communication tool (e.g., email, electronic } \\
\text { discussion) }\end{array}$ & \\
\hline
\end{tabular}




\section{APPENDIX B}

\section{Florida Department of Education's Guide to Calculate Reading Learning Gains:}

Including learning gains as a performance measure for determining school grades was initiated in 2002. It emphasizes the importance of learning a year's worth of knowledge in a year's worth of time. Individual student learning gains are determined by comparing each student's prior year test score to the current year test score using three different methods as described below. Schools earn one point for each percent of students who make learning gains in reading. Beginning in 2012, students who move from any lower FCAT 2.0 Reading achievement level to level 4 are weighted at a value of 1.1 in the numerator, and students who move from any lower FCAT 2.0 Reading achievement level to level 5 are weighted at a value of 1.2 in the numerator.

Students make learning gains if they:

a. Improve one or more FCAT 2.0 achievement levels (e.g., from 1-2, 2-3, 3-4, or 4-5) or Florida Alternate Assessment (FAA) performance levels (for students with significant cognitive disabilities);

b. Maintain a proficient achievement level on the FCAT 2.0 or FAA (at least level 3 for the FCAT 2.0, level 4 for the FAA) without decreasing a level; or

c. Demonstrate more than one year's growth when remaining in achievement level 1 or 2 on the FCAT 2.0 (or when remaining at performance level 1, 2, or 3 for the FAA) for both years. Under this alternative, one year's growth on the FCAT 2.0 is defined in terms of the difference between a student's current year and prior year FCAT 2.0 vertical scale score. To make learning gains, students who remain at level 2 on the FCAT 2.0 have to score at least one 
point beyond a year's expected growth. Students who remain at level 1 have to score at least two points beyond a year's expected growth. These students are credited with learning gains for reading if their vertical scale score improves by at least the amount shown in Table 2. FAA students who remained at performance level 1, 2, or 3 are credited with gains if their score improves by at least five (5) points (raw points) compared with the prior year's score.

Note: Retained students who remain at level 1 or at level 2 will be required to demonstrate the same amount of growth as non-retained students at the same current grade level. For instance, a retained 5th grader at level 1 would be required to increase his/her reading score by at least 10 scale score points. However, students who are retained 3rd graders would be expected to show the same increase in scores as required for 4th graders (the next grade up). Also, when a student's achievement level drops (e.g., from level 4 to level 3), the student is not counted as having made learning gains, even if the lower score is on or above grade level.

\section{Table 10}

\section{Vertical Scale Score Increases Required for FCAT 2.0 Reading Learning Gains}

Reading Grade 3-4 Grade 4-5 Grade 5-6 Grade 6-7 Grade 7-8 Grade 8-9 Grade 9-10

Level 1

12

10

9

8

7

6

8

Level 2

11

9

8

7

6

5

Additional Weighting Provision. When students whose prior-year score is at FCAT 2.0 levels 1 or 2 (or FAA levels 1, 2, or 3 ) increase their FCAT 2.0 vertical 
score (or FAA raw score) by an amount that is at least $33 \%$ greater than the minimum amount of increase required to make learning gains, these students will be weighted at 1.1 (instead of 1.0) in the numerator of the learning gains calculation. (Note: This provision is not limited to students who remained at the same achievement level in both years. Also, students who receive extra weighting for moving up to level 4 or 5 on the FCAT 2.0 would not receive further/additional weighting from this provision.) (Excerpted from Florida Department of Education's “2012 Guide to Calculating School Grades", a technical assistance paper prepared by the staff in the Bureau of Accountability Reporting; Division of Accountability, Research, and Measurement) 


\section{APPENDIX C}

\section{Teacher Letter}

\section{Dear Colleagues,}

I hope you had a wonderful Christmas Holiday, and a restful time with your families. The week prior to the Holiday break, I sent you an email asking for your participation in an important survey I am conducting under Florida International University's Leadership and Professional Studies Department, with the approval of your principal, Dr. Cabrera, and the Miami-Dade County Public School's Research Review Committee. The study is designed to better understand the relationship between teachers' technical literacy and student achievement, and it should take no more than ten minutes of your valuable time to complete. Your school was selected because it represents the diversity of our students in South Florida. Previous research has indicated that students learn better in a real life context using a career theme as the core of instruction. This survey is an important component of my dissertation for an Ed. D in Adult Education/Human Resource Development at Florida International University.

Your participation in the research will be in the form of a short online survey, consisting of a few demographic questions, and questions on attitudes toward use of technology in the classroom. It should take 10 minutes or less to complete. Information from the Florida Inventory of Teacher Technology Skills will also be used in the study. It is important that you know all information will remain strictly confidential, and will be reported as a group; no individual or school site will be disclosed or identifiable except to the researcher. Participants are recruited on a voluntary basis, and may leave the study at any time without incurring any penalty.

Results of the research will advance the field of career education and situated learning, and may serve to identify future areas for professional development. Contact with instructors will be limited to the online survey and written notifications, as approved by the District office. No contact with students will be made at any time, and the educational process will not be affected in any way. No risk to the participants will be involved in collecting this data and the strictest ethical human research methods and protection of confidentiality will be observed.

In the next few days, Mr. Sarmiento will be sending this same letter in an email, so that you may simply click on the link at the bottom of the page to take the survey. Your participation is vital to our research. As a measure of our appreciation, participating teachers will be invited to a complimentary in-service on Developing Courses for Career Academies to be given during a teacher Professional Development Day. You will learn how to design courses that meet industry certification standards. The session will last half a day, and you can earn six Master Plan points.

Should you need help completing the survey or have any questions or concerns, please

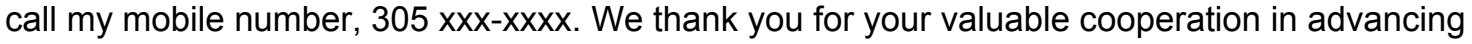
Career Academies in our schools. I wish the most successful year, and many blessings for you and your family in 2012 !

Jorge Gómez, FIU Doctoral Candidate

SPED/EBD Teacher, Hialeah Senior High School

Media Specialist

Please click on the link below and follow the instructions to fill out the online survey (you may also copy and paste the link to your browser address bar). Paper and pencil versions of the survey are also available upon request.

http://surveygoldplus.com/s/CA1B0535BCA6426B/29.htm

Thank you! 
VITA

JORGE GOMEZ MARTIN

March 24, 1950

1968-1972

1973-1975

1975-1979

1979-1995

1994-1995

1995-2001

$1995-2014$

1999-2014

2000-2003

2003-2005
Born, Luyano, Havana, Cuba

B.A., Theater/Humanities

Florida Presbyterian (Eckerd) College

St. Petersburg, Florida

M.A., Theatrical Production and Stage Design

University of Miami

Coral Gables, Florida

Language Arts, Social Studies, and ELL Teacher

Miami-Dade County Public Schools

Miami, Florida

Theatrical and Television Production Designer (Owner) Apollo Lights and Sound, Inc.

Miami, Florida

Technical Theater Instructor/Director, Magnet Programs Miami-Dade County Public School

Miami, Florida

Television Broadcast Operations/Drama Teacher

Miami-Dade County Public Schools

Miami, Florida

Professional Educator Certificate (TV Production/Voc.) Miami-Dade County Public Schools

Miami, Florida

Certification, Local Area Vocational Director, Vocational Florida Department of Education

Tallahassee, Florida

Educational Specialist, Division of Applied Technology Miami-Dade County Public Schools Miami, Florida

Workforce Development Specialist, OPI Miami-Dade County Public Schools Miami, Florida 
2004-2014

2007-2009

2006-2010

2009-2014

2009-2014

2010-2011

2011- 2013

2013-2014
Certification, Exceptional Student Education

Florida Department of Education

Tallahassee, Florida

Adjunct Professor, Vocational Certification Courses Florida International University, College of Education Miami, Florida

Special Education Teacher, Language Arts/Math Miami-Dade County Public Schools Miami, Florida

Certification, Media Specialist Professional Certificate Florida Department of Education

Tallahassee, Florida

Certification, Drama K-12 Professional Certificate Florida Department of Education

Tallahassee, Florida

Educational Media Specialist

Miami-Dade County Public Schools

Miami, Florida

Special Education Teacher, Intellectual Disabilities

Miami-Dade County Public Schools

Miami, Florida

Educational Media Specialist

Miami-Dade County Public Schools

Miami, Florida 